\title{
Essays in Corporate Finance and Labor Economics
}

\author{
by \\ Xiaoyang Li \\ A dissertation submitted in partial fulfillment \\ of the requirements for the degree of \\ Doctor of Philosophy \\ (Business Administration) \\ in The University of Michigan \\ 2011
}

Doctoral Committee:

Professor Jan Svejnar, Co-Chair

Associate Professor Amy K. Dittmar, Co-Chair

Professor Charles C. Brown

Professor Francine Lafontaine

Associate Professor Amiyatosh K. Purnanandam

Associate Professor Uday Rajan 
(C) Xiaoyang Li 2011

All Rights Reserved 
To My Family 


\section{ACKNOWLEDGEMENTS}

I have been blessed to be surrounded by many extraordinary people during the writing of my dissertation. I owe my gratitude to all those people who have made this dissertation possible and because of whom my experience at Michigan has been one that I will cherish forever.

First and foremost, I am deeply indebted to members of my dissertation committee. Five years ago, when I first entered Jan Svejnar's office to ask about research topics, I found a person who I right away wished would agree to be my advisor. Jan always sets high standards for me and inspires me to achieve those standards. He gave me the freedom to pursue research interests on my own and, at the same time, guided me to focus when

I digressed. Amy Dittmar was always there to listen and give invaluable advice. She taught me to question thoughts and express ideas. Her role as a "devil's advocate" greatly honed my thinking. I appreciate her support and encouragement during my job searching process. Francine Lafontaine always cuts to the crux of an intellectual matter. She delivered constructive criticisms of high value and she did so in her own elegant manner. Her clarity of thought constantly awes me. Amiyatosh Purnanandam's insightful comments were thoughtprovoking and they helped me sharpen my ideas. After each meeting with him I felt a little "wiser". Uday Rajan is one of the best teachers that I have had in my life. He constantly challenged me to grow intellectually at different stages of my research and is always readily available to comment on my half-baked research ideas. Charlie Brown's emails usually came in after midnight but with a thoughtful suggestion to address empirical issues in my paper. His wry sense of humor and passion for high quality research make him an incredible asset to my committee. I consider myself extremely fortunate to have them as my committee members and I admire them greatly on both a professional and personal level. 
Apart from my committee, I would like to acknowledge many faculty members who have been instrumental to my academic development. I am especially thankful to Kenneth Ahern. He carefully read and commented on various versions of my job market paper and helped me improve when it counted. I thank him for his mentoring and his friendship. I am grateful to Angie Low and Anil Makhija, co-authors of chapter 4 in this dissertation. They generously allowed me to work with the Census data and introduced me to research on career concerns. Angie was also the first reader of my job market paper. I was fortunate to work with Jagadeesh Sivadasan as a research assistant. His insistence on writing a short Stata do-file turned out to be extremely helpful down the road.

This dissertation would not have been possible without the generous support of several institutions. I am grateful to staff at the Michigan Census Research Data Center. Maggie Levenstein first mentioned to me the possibility of using Census data to conduct research and Clint Carter assisted me in putting together the data I used. I thank the business economics department and finance department for providing a stimulating research environment. I acknowledge various fellowships I received from the Ross School of Business. As a 2010 Kauffman Dissertation Fellow, I thank the financial support from the Ewing Marion Kauffman Foundation.

I am also thankful to the following friends for their various forms of support during my life at Michigan - Yuriy Gorodnichenko, Alex Hsu, Di Li, Yao Lu, Nick Powers, Sarah Stith, Nathan Wilson, Chen Xue, and Min Zhu. Maggie Zhou, who has been a wonderful collaborator and warm-hearted friend, deserves my sincere gratitude. Most importantly, I thank Xuan Zhou for her patience and support throughout this process.

Finally, none of this would have been possible without my family. My family has been a constant source of love, concern, support, and strength all these years. To my family I dedicate this dissertation. 


\section{TABLE OF CONTENTS}

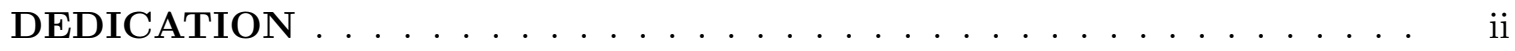

ACKNOWLEDGEMENTS ................... iii

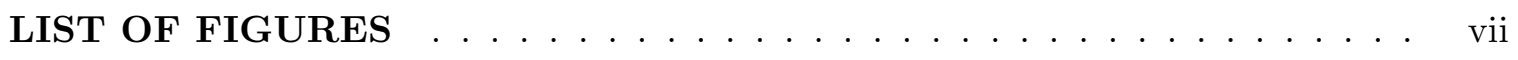

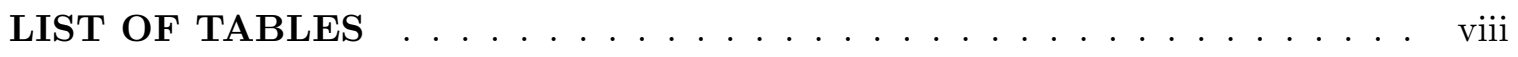

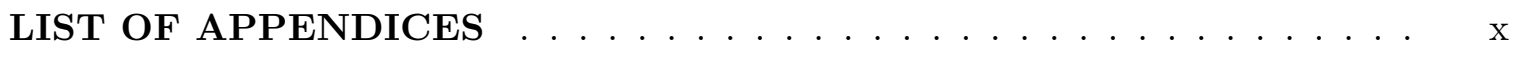

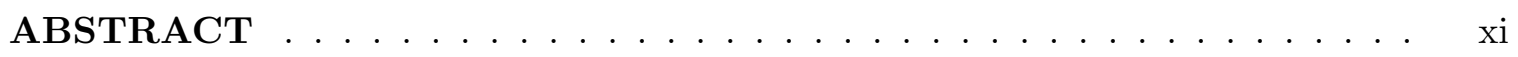

\section{CHAPTER}

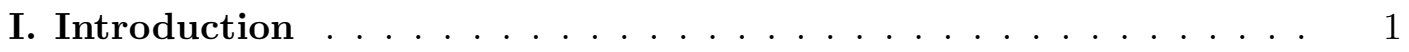

II. Productivity, Restructuring, and the Gains from Takeovers . . . 4

2.1 Introduction . . . . . . . . . . . . . . . . . 4

2.2 Hypothesis development and related literature . . . . . . . . . . 9

2.2.1 Effect of takeovers on productive efficiency . . . . . . . . 9

2.2 .2 Sources of efficiency gains . . . . . . . . . . . . . . 10

2.2.3 Determinants of combined announcement returns . . . . . 11

2.2.4 Determinants of offer premiums . . . . . . . . . . . 14

2.3 Data sample and variable construction . . . . . . . . . . . . 15

2.3.1 Identifying mergers and acquisitions . . . . . . . . . 15

2.3.2 Matching mergers to census establishment data . . . . . . 16

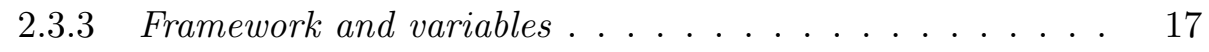

2.3.4 Descriptive statistics . . . . . . . . . . . . . . . . . 19

2.3.5 Control group .................... . 20

2.4 Real effects of takeovers . . . . . . . . . . . . . . 22

2.4.1 Effects on productive efficiency .................. 22

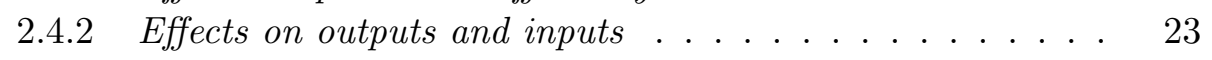

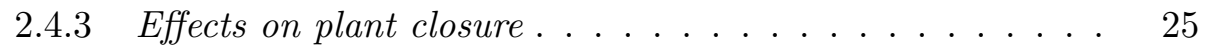

2.4 Robustness checks . . . . . . . . . . . . 26

2.4.5 Acquirers' incumbent plants .............. . 28 
2.5 Determinants of announcement returns . . . . . . . . . . .

2.5.1 Effects of changes in productivity and payroll on combined

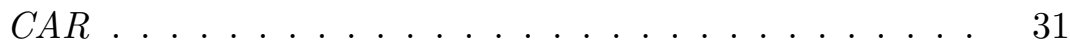

2.5.2 Effects of changes in productivity and payroll on premium 32

2.5.3 Effects of changes in productivity and payroll on acquirer CAR ..................... 34

2.5.4 Further tests of employee wealth redistribution hypothesis . $\quad 35$

2.6 Conclusions . . . . . . . . . . . . . . 36

III. Unions, Workers, and Takeovers _. . . . . . . . . . . . . 52

3.1 Introduction . . . . . . . . . . . . . . . . . . . 52

3.2 Literature review . . . . . . . . . . . . . . 57

3.3 Effect of union strength on shareholder gains . . . . . . . . . . 59

3.3.1 Identifying mergers and acquisitions . . . . . . . . . . 59

3.3.2 Union membership ................. . . 59

3.3.3 Variables and specifications ............. 60

3.3.4 Results...................... 61

3.4 Effect of union strength on labor outcomes . . . . . . . . . . 63

3.4.1 Matching mergers to census establishment data . . . . . 63

3.4.2 Descriptive statistics . . . . . . . . . . . . . . . 64

3.4 .3 Variables. . . . . . . . . . . . . . . . 65

3.4.4 Empirical methodology ............... . 65

3.4.5 Effect of takeover on wage and employment . . . . . . . . 66

3.4.6 Impact of union . . . . . . . . . . . . . . . . . 69

3.5 Conclusions and future research . . . . . . . . . . . . . 71

IV. Career Concerns and the Busy Life of Young CEOs . . . . . . . . 80

4.1 Introduction . . . . . . . . . . . . . . . 80

4.2 Literature review and hypotheses development . . . . . . . . . 86

4.3 Data . . . . . . . . . . . . . . . . . 90

4.3.1 Classification of plant-level activities . . . . . . . . . . 90

4.3.2 Plant productivity and capital expenditures . . . . . . . . . 93

4.3.3 Firm financial variables and CEO age . . . . . . . . . 94

4.3.4 Summary statistics . . . . . . . . . . . . . . . . 95

4.4 Empirical analysis . . . . . . . . . . . . . . . . . . . . 96

4.4.1 CEO age and investment. . . . . . . . . . . . . . 97

4.4.2 Alternative hypotheses and robustness checks. . . . . . . 100

4.4.3 Characteristics of investment activities . . . . . . . . . . 103

4.4.4 Effect of CEO age on plant productivity . . . . . . . . . 106

4.4.5 Capital allocation across plants . . . . . . . . . . . . 109

4.5 Conclusions . . . . . . . . . . . . . . . . . . . 110

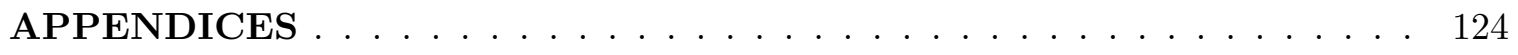

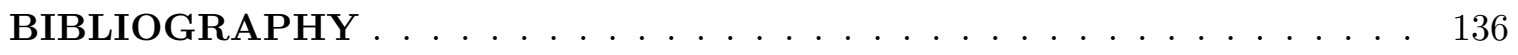




\section{LIST OF FIGURES}

\section{Figure}

B.1 Union Membership across states, years and industries . . . . . . . 133

B.2 Map of Right-to-work law states . . . . . . . . . . . . . . . 134

B.3 Real Investment Activities across years . . . . . . . . . . . . . . . 135 


\section{LIST OF TABLES}

\section{$\underline{\text { Table }}$}

$2.1 \quad$ Number of Deals and Basic Deal Characteristics . . . . . . . . . . . . . 39

2.2 Descriptive Statistics for Target Firm/Plant Output and Employment . . 40

2.3 The Effect of Takeovers on Efficiency . . . . . . . . . . . . . 41

2.4 The Effect of Takeovers on Outputs and Inputs . . . . . . . . . . . . 42

2.5 The Effect of Takeovers on Plant Closure . . . . . . . . . . . . . . . 43

2.6 The Effect of Takeovers on Efficiency with a Different Control Sample . . 44

2.7 The Effect of Takeovers on Outputs and Inputs with a Different Control Sample . . . . . . . . . . . . . . . . . . 45

2.8 Summary Statistics of Key Variables in Announcement Returns Analysis . 46

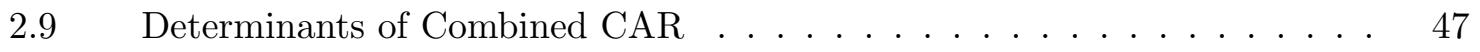

2.10 Determinants of Offer Premium . . . . . . . . . . . . . 48

2.11 Determinants of Acquirer CAR . . . . . . . . . . . . 49

2.12 Wealth Redistribution between Employees and Shareholders in Dollars . . 50

2.13 Redistribution between Employees and Shareholders from Fringe Benefits 51

3.1 The Effect of Union Power on Target and Acquirer's shareholder gains . . 73

3.2 The Effect of Union Power on Combined CAR and Target's Share of Gains 74

$3.3 \quad$ Number of Takeovers Matched to LBD . . . . . . . . . . 75

$3.4 \quad$ Descriptive Statistics . . . . . . . . . . . . 76 
3.5 The Effect of Takeovers on Wage and Employment . . . . . . . . . . 77

3.6 The Effect of Union on Wage and Wage Growth . . . . . . . . . . . . 78

3.7 The Effect of Union on Employment and Employment Growth _ . . . . 79

$4.1 \quad$ Summary Statistics . . . . . . . . . . . . . . . . . . 112

$4.2 \quad$ Effect of Age on Investment Activity . . . . . . . . . . . . . . . . 113

4.3 Effect of Age on Investment Activity using Age Cohorts . . . . . . . . . . 114

$4.4 \quad$ Effect of Age on Investment Activity: Firm Fixed Effects _ . . . . . . . 115

4.5 Effect of Age on Investment Activity: Propensity Score Matching . . . . . 116

$4.6 \quad$ Effect of Age on Investment Activity: CEO Fixed Effects _ . . . . . . . 117

$4.7 \quad$ Effect of Age on Employment Growth _ . . . . . . . . . . . 118

4.8 Effect of Age on Capital Expenditures and R\&D Expenditures . . . . . . 119

4.9 De Novo vs. Acquisition . . . . . . . . . . . . . . . 120

4.10 Effect of CEO Age on Plant Productivity . . . . . . . . . . . . . 121

4.11 Effect of CEO Age on Acquired Plant's Productivity . . . . . . . . . . . . 122

4.12 Capital Expenditure: Inherited vs. Not-Inherited Plant . . . . . . . . 123 


\section{LIST OF APPENDICES}

\section{Appendix}

A. Variable Description and Sample Construction for Chapter $2 \ldots \ldots$. . . . 125

B. Variable Description for Chapter $4 \ldots \ldots \ldots$. . . . . . . . . . 129 


\begin{abstract}
Essays in Corporate Finance and Labor Economics

by

Xiaoyang Li
\end{abstract}

Co-Chairs: Jan Svejnar and Amy K. Dittmar

My dissertation is composed of three essays addressing the following three questions: First, how do mergers and acquisitions create value? Second, what role do labor unions play in affecting merger outcomes? Third, how do CEOs' career concerns impact firms' restructuring decisions?

In the first essay, I investigate the underlying sources of gains from takeovers. Using plant-level data from the U.S. Census Bureau, I show that acquirers significantly reduce investments, wages, and employment in target plants, though output is unchanged relative to comparable plants. Acquirers also aggressively shut down target plants. Moreover, these changes help explain the merging firms' announcement returns. The total announcement returns to the combined firm are driven by improvements in the target firm's productivity. Also, targets with greater post-takeover productivity improvements receive higher premiums from acquirers. These results provide some of the first empirical evidence on the direct relation between productivity, labor, and stock returns in the context of takeovers.

In the second essay, I examine the role of labor unions in takeovers. I show that gains to merging firms' shareholders are positively associated with target's union membership. Also, target's shareholders capture a larger share of joint gains when the target's union membership is lower. I then analyze the wage and employment outcomes for a large sample 
of firms that were acquired between 1981 and 2002. I find that after a takeover, target establishments exhibit net decline in wages and employment, especially when target's union membership is high. These results highlight the role of takeovers in unlocking the economic rents previously captured by labor unions.

In the third essay, I compare how career concerns affect the real investment decisions of younger and older CEOs. I show that younger CEOs undertake more active investment activities. They are more likely to enter new lines of business, as well as exit existing lines of business. They prefer growth through acquisitions, while older CEOs prefer to build new plants. This busier investment style of the younger CEOs appears to be relatively successful since younger CEOs are associated with higher plant-level efficiency compared to older CEOs. 


\section{CHAPTER I}

\section{Introduction}

A large body of work in finance and economics is devoted to understanding the causes and effects of takeovers and restructuring. In my dissertation, I use plant-level data from the U.S. Census Bureau to provide a micro-level view of corporate takeovers and restructuring. In particular, I attempt to address the following three questions: First, how do mergers and acquisitions create value? Second, what role do labor unions play in affecting merger outcomes? Third, how do CEOs' career concerns impact firms' restructuring decisions. I contribute to the existing literature in three important ways: First, I peer inside the black box of firm operations to uncover the detailed changes that are affected by takeovers and are affected by CEO's personal characteristics. Second, I incorporate labor and labor unions into consideration when I analyze the effects of takeovers. Third, I explore the interconnections between product market, labor market, and the stock market, in the context of mergers and acquisitions.

My dissertation is composed of three essays. In essay 1, I investigate the underlying sources of gains from takeovers. Though it is well documented that takeovers increase the combined equity value of targets and acquirers, relatively little is known about the sources of such gains. In this essay, I uncover the underlying sources of gains from takeovers in two steps. First, by examining changes to output levels, input choices, and plant closures after

a takeover, I identify some detailed channels through which the acquiring firm enhances the target firm's productivity. I show that acquiring firms increase the productivity of target's plants through more efficient use of investments and labor and through aggressive plant closures. Second, I relate these underlying efficiency gains to the cross-sectional differences 
in announcement period stock returns. Most existing studies regress announcement returns on various imperfect proxies for economic gains such as Tobin's Q, insider and analyst forecasts of synergies, operating cash flow, corporate governance measures, and product market differentiation. My paper differs from these studies by regressing announcement returns directly on a measure of plant-level productivity, which is a more fundamental determinant of economic efficiency and is less subject to noise in accounting information surrounding the mergers. To the best of my knowledge, this is the first study that explores the relation between stock returns and plant-level productivity in the context of takeovers. I also jointly test the redistribution theory of takeovers from the employees' perspective. Some argue that gains to shareholders simply represent wealth redistribution from employees. I find that the total announcement returns to the combined firm are driven by improvements in target firm's productivity, rather than cutbacks in wages and employment. In sum, I provide some of the first empirical evidence on the direct relation between productivity, labor, and stock returns in the context of takeovers.

In my second essay, I analyze the role of labor unions in takeovers. Anecdotes suggest that labor unions play an important role in the process of mergers and acquisitions. However, empirical evidence about how labor unions affect merger outcomes is scant. In this study, I investigate the role of labor unions in takeovers by examining their effect on shareholders and workers. I show that target firm's union membership and the difference in membership between targets and acquirers affect changes to shareholders wealth. First, gains to merging firms' shareholders are positively associated with target's union membership, but are negatively associated with the difference in union membership. Second, the target's shareholders capture a larger share of joint gains when the target's union is weaker. To provide insights into why unions might affect shareholder values, I analyze wage and employment outcomes for a large sample of firms that were acquired between 1981 and 2002, using establishment-level data from the U.S. Census Bureau. I find that after a takeover, target establishments exhibit net declines in wages and employment, relative to comparable establishments. Higher union membership for the target firm is associated with greater wages and employment reductions. These results highlight the role of takeovers in unlocking the economic rents previously captured by labor unions. 
The last essay is joint work with Angie Low and Anil Makhija. We examine the impact of CEO's career concerns on firm's investment decisions. Theory has long recognized that a firms' investment decisions are contaminated by its managers' career concerns. Yet the limited available empirical evidence on career concerns is mostly about some specialized labor markets, such as mutual fund managers, security analysts, and macroeconomic forecasters. Studies have found evidence that younger decision makers avoid bold decisions, preferring to "herd" rather than standout and risk a negative outcome that could adversely affect their careers. We compare how career concerns affect the real investment decisions of younger and older CEOs. In contrast to prior research, we find that younger CEOs undertake more active, bolder investment activities, consistent with an attempt on their part to signal confidence and superior abilities. They are more likely to enter new lines of business, as well as exit other lines of business. They prefer growth through acquisitions, while older CEOs prefer to build new plants. This busier investment style of the younger CEOs appears to be relatively successful since younger CEOs are associated with higher plant-level efficiency compared to older CEOs. Taken together, these results suggest that younger CEOs are busy sending active signals to the managerial labor market by taking on bold, speedy, and efficiency-creating investment activities compared to older CEOs.

As a final note, the research was conducted when I was a Special Sworn Status researcher of the U.S. Census Bureau at the Michigan Research Data Center (RDC). Any opinions and conclusions expressed herein are those of the author and do not necessarily represent the views of the U.S. Census Bureau. All results have been reviewed to ensure that no confidential information is disclosed. Support for this research at the Michigan RDC from NSF (ITR-0427889) is also gratefully acknowledged. 


\section{CHAPTER II}

\section{Productivity, Restructuring, and the Gains from Takeovers}

\section{$2.1 \quad$ Introduction}

Though it is well documented that takeovers increase the combined announcement returns for targets and acquirers (Andrade, Mitchell, and Stafford, 2001), solely focusing on market reaction to takeover announcements is unable to identify the sources of such gains. To shed light on how takeovers create value, several studies examine changes in plant-level productivity. For instance, Maksimovic and Phillips (2001) show that takeovers are followed by improved productivity. ${ }^{1}$ These studies, however, do not attempt to identify the detailed mechanisms that lead to these changes in productivity. Yet identifying these mechanisms is crucial to both researchers and practitioners to understand what factors influence a merger's success or failure. In addition, surprisingly little empirical evidence exists on the direct relation between announcement returns and productivity gains or losses. Determining whether such a relation exists is important because, if so, it suggests that the stock market is not a sideshow, but rather it embeds information about the underlying efficiency changes. The goal of this study, therefore, is to uncover the sources of gains from takeovers and to relate them to the cross-sectional differences in announcement returns.

In this paper, I show that acquiring firms increase the productivity of targets through more efficient use of investments and labor and through aggressive plant closures. I also find that the combined firms' announcement returns reflect these underlying efficiency improvements. I conduct the analysis on 1,430 mergers completed between 1981 and 2002,

\footnotetext{
${ }^{1}$ Other studies, including Lichtenberg (1992), McGuckin and Nguyen (1995), Yang (2008), Maksimovic, Phillips, and Yang (2010), and Maksimovic, Phillips, and Prabhala (2010) find similar results.
} 
using data from the Securities Data Company's Mergers and Acquisitions database and confidential plant-level data from the U.S. Census Bureau. These data allow me to identify detailed changes in plant-level output and input from before to after the takeover. I first examine whether takeovers affect targets' total factor productivity (TFP). Using a differences-in-differences regression approach, I find that the target plants' TFP experiences net improvement relative to comparable plants following a takeover.

I next pinpoint the detailed channels through which these productivity gains are created. I address this question by separating TFP into output and input components and comparing changes to output vis-à-vis input following a takeover. I show that, relative to comparable plants, capital expenditures, wages, and employment all experience substantial declines while output remains constant. Essentially, the acquiring firm produces the same amount of output using less input. This indicates that increases in productivity stem primarily from acquiring firms' more efficient use of capital and labor. I also find that employee layoffs are concentrated mostly among non-production workers in target plants, which supports the hypothesis that acquirers reduce management slack and transfer their own management know-how. These findings are consistent with anecdotal evidence. For example, after the pharmaceutical firms Merck and Schering-Plough merged in late 2009, the new firm announced a restructuring initiative to streamline its operations to achieve synergy. In an open announcement, Richard Clark, CEO of Merck, announced that 16,000 jobs would be cut ( $15 \%$ of the workforce) and that this restructuring program was intended to save $\$ 2.6$ billion to $\$ 3$ billion by 2012 , accounting for nearly $80 \%$ of the total synergy benefits the two firms had set to gain. ${ }^{2}$

In addition to downsizing and making more productive use of inputs in the continuing plants, I show that the acquirers also aggressively shut down target plants. According to my findings, three years following a takeover, target plants are 6.9 percentage points more likely to be shut down than control plants. In addition, plants with lower initial TFP are more likely to be closed.

Building on these findings, I take the current research a step further by connecting a

\footnotetext{
${ }^{2}$ http://blogs.wsj.com/health/2010/01/06/what-mercks-ceo-said-today-about-possible-jobcuts $/ \bmod =$ yahoohs
} 
target's productivity gains and labor cost savings to combined firm's announcement returns. The literature on corporate control proposes that the total gains to shareholders should reflect value creation via efficient allocation of resources (Jensen and Ruback, 1983). I refer to this proposition as the efficiency creation hypothesis. Some dispute this claim by arguing that gains to shareholders simply represent wealth redistribution from other stakeholders such as government, bondholders, consumers, and employees (Shleifer and Summers, 1988). I refer to this argument as the employee wealth redistribution hypothesis. Under the efficiency creation hypothesis, gains to the combined firm's shareholders capitalize future productivity improvements. In contrast, under the employee wealth redistribution hypothesis, such gains come largely from employee wealth losses, potentially through wages and employment reductions .

To test the efficiency creation hypothesis versus employee wealth redistribution hypothesis, I construct two variables, $\Delta \mathrm{TFP}$ and $\Delta$ Payroll, measuring the target firms' pre- and post-takeover percentage changes in productivity and payroll (total salaries and wages) and regress the combined announcement returns on these two variables. The analysis on the combined firm's announcement return is concerned with the total synergy gains a merger generates. The results show that post-takeover improvements in productivity $(\Delta \mathrm{TFP})$ are positively associated with the total synergy gains, especially when the target is relatively large compared with the acquirer. Ceteris paribus, compared with acquiring a target at the 25 th percentile of $\triangle \mathrm{TFP}$, acquiring a target at the 75 th percentile increases the combined three-day announcement returns by 1 percentage points. If the target's pre-takeover market value is half of the acquirer's, such a change increases the combined returns by about 2.5 percentage points. The economic significance of the point estimates is considerable given that the sample median of the combined return is about $3.5 \%$. In contrast, I find no statistically significant relation between combined announcement returns and labor cost savings ( $\Delta$ Payroll), which contradicts the employee wealth redistribution hypothesis.

I next investigate the gains to the target firm and the acquiring firm separately. Prior literature consistently documents that targets receive high offer premiums from acquirers and capture virtually all of the joint gains (e.g., Moeller, Schlingemann, and Stulz, 2004). Unfortunately, studies have yet to find specific economic gains that warrant such 
high premiums (Betton, Eckbo, and Thorburn, 2008). Many attribute the high premiums to behavioral distortions (Roll, 1986; Malmendier and Tate, 2008; Baker, Pan, and Wurgler, 2010) and agency conflicts (Wulf, 2004; Hartzell, Ofek, and Yermack, 2004; Moeller, 2005). In this study, I hypothesize that the offer premiums are related to the ultimate benefits to acquirers, with target performance improvements under new management being an important part of these benefits. I examine the relation between targets' productivity improvements and the offer premiums they receive and find that target firms with greater post-takeover productivity improvements receive higher premiums from acquirers. Other things being equal, an acquirer pays a target with $\triangle \mathrm{TFP}$ at the 75 th percentile about 10 percentage points higher offer premium than a target at the 25 th percentile. This result is consistent with insights from Rhodes-Kropf and Robinson (2008), who emphasize the target's future expected surplus in determining bargaining outcomes. Lastly, I look at the acquirers' own announcement returns. I show that targets' improvements in productivity have a substantial effect on acquirers' announcement returns only when the target is relatively large compared with acquirer. Overall, the evidence suggests announcement returns are mainly driven by the target's post-takeover improvements in productivity.

This paper makes several contributions to the literature on corporate takeovers. First, I present some direct empirical results on the channels that affect productivity improvements following takeovers. Existing evidence on channels comes mostly from a few clinical studies (see, e.g., Kaplan, 2000; Kaplan, Mitchell, and Wruck, 2000; Hietala, Kaplan, and Robinson, 2003). Contrary to prior research, which often attributes takeover efficiency gains to a broad notion of "synergy" or "better management," I provide substantiating evidence by peering inside the black box of target plants.

Second, this study adds to the literature that explains the cross-sectional variation of merging firms' announcement returns. Most existing studies attempt to regress announcement returns on various imperfect proxies for economic gains such as Tobin's Q (Lang, Stulz, and Walkling, 1989; Servaes, 1991), insider and analyst forecasts of synergies (Houston, James, and Ryngaert, 2001; Devos, Kadapakkam, and Krishnamurthy, 2009), operating cash flow (Healy, Palepu, and Ruback, 1992), corporate governance measures (Masulis, Wang, and Xie, 2007; Wang and Xie, 2009), and product market differentiation (Hoberg 
and Phillips, 2010). My findings corroborate the conclusion that wealth gains to shareholders reflect expectations of improved corporate performance. The crucial difference is that I regress announcement returns directly on a measure of plant-level productivity. This approach originates from Schoar (2002), who shows that stock prices track total factor productivity in both conglomerate and single-segment firms. There are two key advantages in adopting this approach. First, plant productivity is a more fundamental determinant of economic efficiency. Second, using plant level information is less subject to noise in accounting information surrounding the mergers. To the best of my knowledge, this is the first study that explores the relation between stock returns and plant-level productivity in the context of takeovers.

This paper also complements the aforementioned studies by jointly testing the redistribution theory of takeovers from the employees' perspective. While efficiency improvement is socially desirable, shareholder gains from rent expropriation from employees may not be. The potential for such wealth transfers in mergers has become increasingly contentious, especially among policymakers and in the popular press. Research to date has found a small scale of wealth redistribution from labor (e.g., Rosett, 1990; Pontiff, Shleifer, and Weisbach, 1990). Due to data limitations and focus, few studies test the efficiency creation hypothesis versus employee wealth distribution hypothesis head-to-head. This is problematic because the two are often intertwined. For example, an increase in profits could be a result of either efficiency gains or wealth transfer from employees; job losses from employees may well help create efficiency gains. This paper makes the first unified attempt to test these two hypotheses. In sum, I show that improvements in productivity, rather than wealth losses from labor, are associated with higher announcement returns for the combined firm. My findings suggest that takeovers indeed involve wealth transfers from target firm's employees to shareholders, but the extent of such transfers is relatively small. Despite the conspicuous role employees play in mergers and acquisitions, relatively little attention has been paid to labor in the corporate control literature. This study, therefore, contributes to a growing body of literature on the role of labor in corporate takeovers and restructuring (e.g., Pagano and Volpin, 2005; Rauh, 2006; Atanassov and Kim, 2009).

The rest of the paper is structured as follows. In the following section, I present the re- 
search objectives and develop testable hypotheses drawing from existing literature. Section 2.3 describes the data, sample, and variables. Section 2.4 analyzes the effect of takeovers on productive efficiency and other related aspects of operation. In Section 2.5, I investigate possible determinants of merger announcement returns from the perspective of productivity and labor costs changes. Section 2.6 concludes.

\section{$2.2 \quad$ Hypothesis development and related literature}

In this study, I attempt to address two questions:

(1) How do takeovers create productivity gains?

(2) Do announcement returns for the combined firm reflect these productivity gains?

In this section, I discuss the prior literature related to these questions and present hypotheses to guide the empirical analysis.

\subsubsection{Effect of takeovers on productive efficiency}

Traditional corporate finance theories portray takeovers as a market for corporate control, which in turn fosters an efficient allocation of resources. The market discipline hypothesis (also referred to as the inefficient management hypothesis) proposes that managers who pursue objectives other than maximizing profit often fall prey to more efficient firms, which improve efficiency by displacing the managers in the target firm (Martin and McConnell, 1991). A related view holds that takeovers aim to create synergies, which can arise from exploiting increased market power, economies of scale, eliminating duplicate efforts, and combining complementary resources (Hoberg and Phillips, 2010). If the acquisition is driven by either market discipline or synergy creation, then after a takeover, I expect the following hypothesis to hold:

\section{H1: The productivity of the target firm increases after the takeover.}

Agency theories, however, often view mergers and acquisitions as investment actions driven primarily by the CEO's personal objectives - either to build an empire (Jensen, 1986) or to entrench their power over the firm (Shleifer and Vishny, 1989). If an acquisition 
is influenced by conflicts of interest between managers and owners of the firm, the opposite of $\mathbf{H 1}$ will follow:

H1a: The productivity of the target firm does not necessarily increase after the takeover.

Except for a few studies (see, e.g., Ravenscraft and Scherer, 1989; Ghosh, 2001), most studies conclude that takeovers improve target firm's plant-level productivity (see, e.g., Lichtenberg, 1992; McGuckin and Nguyen, 1995; Maksimovic and Phillips, 2001; Maksimovic, Phillips, and Prabhala, 2010). None of these studies, however, explores how takeovers actually achieve productivity improvements, which is the focus of the current study.

\subsubsection{Sources of efficiency gains}

An increase in productivity, measures by TFP requires a relative increase in output compared with inputs. After acquisitions, acquirers have strong incentives to restructure the target firm in order to improve efficiency. Labor expenses and investments account for a large portion of a firm's outlay of financial resource. Meanwhile, corporate decisions on these two expenditures are prone to manager-shareholder agency problems that destroy efficiency. Bertrand and Mullainathan (2003) show that CEOs prefer a "quiet life" by appeasing workers (especially white-collar workers) with excess wages. Jensen's (1986) free cash flow

theory hypothesizes that CEOs sacrifice firm's profitability for size by investing in negative net present value projects. Therefore, adjusting wages, employment, and investment can not only reduce costs, but also increase productive efficiencies. The extreme of such adjustment is to close the entire plant. I thus propose the following hypothesis to test the underlying mechanisms through which productivity might improve:

H2: The acquirer lows target's wage rate, employment, and investments, but the level of output does not decline proportionally.

Lichtenberg and Siegel (1990a,b) document that ownership changes are followed by substantial reductions in administrative overhead, especially the number of "central-office" employees. Such actions are known to create values in leverage buyouts in the 1980s (Shleifer 
and Vishny, 1988). Similarly, Kaplan (1989) documents that capital expenditures declined substantially in a sample of firms involved in management buyouts in the 1980s. Yet Servaes (1994) finds little evidence of investment cutbacks in a sample of 700 firms that went private from 1972 to 1987.

Most of these studies obtain their conclusions using samples of takeovers that occurred in the early 1980s, which were characterized by a flurry of hostile takeovers and leveraged and management buyouts. The landscape of takeovers has changed dramatically since then; thus, updating the evidence is warranted.

Maksimovic and Phillips $(2001,2002)$ argue that a firm engages in asset purchases to exploit its comparative advantage in operating certain segments. Maksimovic, Phillips, and Prabhala (2010) show that acquirers redraw firm's boundary by retaining assets in which they have a comparative advantage in operations, but selling assets peripheral to their operations. My approach differs from their approach by examining whether acquirers shut down underperforming plants expediently.

H2 implies that acquiring firms potentially create efficiency gains by correcting existing inefficiencies such as redundant employment, excessive wages, extra investment, and underperforming plants. Essentially, acquirers downsize and economize the target plants. The necessary condition for these actions to be efficiency-enhancing is that the amount of output does not drop proportionally. An alternative to H2, as shown in McGuckin and Nguyen (2001), is that acquirers make better use of existing inputs and produce more outputs:

H2a: The acquirer increases target's wage rate, employment, and investment, and the level of output increases more than proportionally.

Essentially, H2 predicts that after acquisitions, acquirers economize and downsize targets while H2a predicts that acquirers maintains or expands the scale of operations and produce proportionally greater outputs.

\subsubsection{Determinants of combined announcement returns}

H1 and $\mathbf{H 2}$ are related to whether and especially, how takeovers affect targets productivity. To the extent that the stock market anticipates these activities, stock price reactions 
to merger announcement should capitalize these economic gains and/losses.

Prior literature consistently documents that mergers increase shareholder value for the target and acquiring firm combined. Disagreement remains, however, regarding the sources of these shareholder wealth gains. Two competing theories have been put forward to explain the total gains: Efficiency creation (Jensen, 1986) and wealth redistribution (Shleifer and Summers, 1988). The efficiency creation theory reasons that in an efficient capital market, the combined gains following the merger announcement reflect improved expectations of the merging firms' operating performance. Therefore, the following hypothesis is proposed:

\section{H3 (Efficiency creation hypothesis): Post-takeover improvements in target's} productivity increase combined announcement returns.

Alternatively, the wealth redistribution theory contends that wealth gains to shareholders simply represent wealth losses from other stakeholders. Employees in the target firms are particularly disadvantaged subsequent to a takeover. Presumably, new managers face lesser resistance from the target firm's employees because there is greater understanding that firms must consolidate operations after a merger. Shleifer and Summers (1988) argue that takeovers are in part motivated by the opportunity to renege on implicit labor contracts and that transfers from employees to shareholders account for a large part of the takeover gains. Following this logic, I proposes the following hypothesis to investigate wealth redistribution as a source of gains to shareholders:

\section{H4 (Employee wealth redistribution hypothesis): Post-takeover cuts on labor costs increase combined announcement returns.}

A large literature tests the efficiency creation hypothesis by regressing announcement returns on some measures of economic gains. Using Tobin's Q as a proxy for managerial performance, Lang, Stulz, and Walkling (1989) and Servaes (1991) document that total takeover gain is highest when a well-managed (high Q) firm acquires a poorly-managed (low Q) target. Masulis, Wang, and Xie (2007) and Wang and Xie (2009) find similar evidence using corporate governance measures (G-index). From a sample of the 50 largest mergers between 1979 and 1984, Healy, Palepu, and Ruback (1992) find a positive correlation be- 
tween post-merger increases in operating cash flows and announcements returns. Based on a text-based measure for production market competition and differentiation, Hoberg and Phillips (2010) show that mergers create more value when the potential product market synergy (creating new products that increase product differentiation) is greater. Houston, James, and Ryngaert (2001) show that merger gains are associated with the acquiring firm's management forecasts of synergies in a sample of 41 banking mergers. Drawing information from the Value Line, Devos, Kadapakkam, and Krishnamurthy (2009) find that announcement returns correspond to analyst forecasts of synergies. While these studies all conclude that gains to shareholders reflect efficiency improvements, their approaches are subject to the criticisms that these variables $(\mathrm{Q}$, governance, cash flow, product market competition, and synergy forecasts) represent at best noisy measures of economic gains.

On the other hand, large-sample empirical support for the employee wealth redistribution hypothesis has been inconclusive and rather limited. Brown and Medoff (1988) report evidence that mergers are associated with wage declines of about $4 \%$ and employment growth of about $2 \%$ in a sample of small firms in Michigan. McGuckin and Nguyen (2001) find that ownership changes are associated with positive outcomes in terms of jobs, wages, and plant survival probability. Ouimet and Zarutskie (2010) also show that average employee wage increases following a merger. In a sample of 413 takeovers between 1981 and 1988, Pontiff, Shleifer, and Weisbach (1990) report that pension funds reversions are more likely following a hostile takeover, but these pension reversions amount to a small portion of the takeover premiums. Rosett (1990) concludes that a wealth transfer from workers to shareholders accounts for $10 \%$ of the hostile-takeover premium, and only $5 \%$ for friendly takeovers. The majority of evidence seems to suggest that wealth redistribution from labor alone cannot explain gains to the target and acquiring firm shareholders.

An empirical challenge arises because efficiency creation hypothesis and employee wealth redistribution hypothesis are not mutually exclusive. While wage reductions and employee layoffs redistribute wealth to shareholders, they are also likely to be part of a restructuring process that increases productive efficiency. As a result, simply looking at the relation between announcement returns and changes in wages and employment is insufficient to distinguish one from the other. I address this challenge through two additional empirical 
exercises. First, in addition to focusing on wage and employment changes, I also examine changes to fringe benefits (pension benefits, unemployment benefits, and health insurance etc.) as a source of employee wealth redistribution. Second, I estimate the redistribution ratio (defined as the dollar changes in shareholder wealth in response to a dollar cut in employee wealth) between employee wealth and shareholder wealth to test whether this ratio is greater than one. If this redistribution ratio is greater than one, employee wealth cuts probably entail additional gains to shareholders beyond the pure transfer. I discuss the details of these two tests in Section 2.5.4.

\subsubsection{Determinants of offer premiums}

I next turn attention to the offer premiums that targets receive from acquirers. A robust empirical finding in the literature is that the target firms' shareholders capture most of the joint gains. ${ }^{3}$ For example, Moeller, Schlingemann, and Stulz (2004) report that targets receive premiums of about $65 \%$ and acquirers' three-day announcement returns are only about $1 \%$. Little is known about what economic factors, if any, drive such high offer premiums. ${ }^{4}$ Research to date mostly attributes the high premiums to some behavioral or agency distortions. One influential view by Roll (1986) postulates that such a high offer premium results from the acquirer CEO's hubris. Even if the acquiring firm can benefit from acquiring the target, the acquiring firm overpays for these benefits due to excessive selfconfidence. Recently, Baker, Pan, and Wurgler (2010) find that offer premiums are geared toward the target's past 52-week highest price pre-merger as a "reference point". The target firm's agency conflicts can also affect the target premiums. Wulf (2004) and Hartzell, Ofek, and Yermack (2004) both suggest that target's CEO trades private benefits for premiums. In a similar vein, Moeller (2005) shows that target shareholder control, proxied by low target CEO share ownership, low fractions of inside directors, and the presence of large outside blockholders is positively correlated with offer premiums.

These behavioral and agency based explanations for offer premiums are in contrast

\footnotetext{
${ }^{3}$ Ahern (2010) provides contrary results based on inference from division of merger gains in dollar value.

${ }^{4}$ Bargeron, Schlingemann, Stulz, and Zutter (2008) find that privates acquirers pay lower premiums than publicly-listed acquirers. Officer (2003) and Bates and Lemmon (2003) show that offer premiums are greater when the deal indicates the existence of a target termination agreement.
} 
to the efficiency-driven explanation. Rhodes-Kropf and Robinson (2008) argue that the complementary nature of target's asset to acquirer's asset and target's future expected surplus determine its bargaining position. If I assume that targets' realized productivity improvements are correlated with targets' expected surplus ex ante, targets with greater ex post productivity improvements are in a relative stronger bargaining position. Therefore, they are able to demand higher premiums. I thus propose the following hypothesis to examine whether offer premiums can be explained by target's post-takeover productivity gains.

H5: Targets with greater post-takeover productivity improvements receive higher offer premiums from acquirers.

\subsection{Data sample and variable construction}

I exploit plant-level data from the U.S. Census Bureau to test the above hypotheses. The main data used in this paper come from a linked sample between the Annual Survey of Manufacturers (ASM), the Census of Manufacturers (CMF), Longitudinal Business Database (LBD), maintained at the U.S. Census Bureau, and the Securities Data Company's (SDC) Mergers and Acquisitions database. This section describes the sample.

\subsubsection{Identifying mergers and acquisitions}

The data on mergers and acquisitions are taken from the SDC's U.S. Mergers and Acquisitions database. Only deals completed between January 1, 1981 and December 31, 2002 and completed within 360 days of the announcement are included. ${ }^{5}$ The transaction value of the deal is restricted to be at least 1 million U.S. dollars and the targets must be publicly-listed with stock prices available from the Center for Research in Security Prices (CRSP). Acquirers must own less than 50\% of the target's shares before and $100 \%$ after the merger. Acquirers may be public, private, or subsidiaries of public or private firms. I then match these targets (using the target's CUSIP and ticker) to firms in the ASM and

\footnotetext{
${ }^{5}$ I restrict the deals to be completed by 2002 because current Economic Census data is available until 2005 and I want to follow the plants three years after the merger. I require the deals to be completed within 360 days so that I can identify the merger completion year cleanly.
} 
CMF database. ${ }^{6}$ A total of 1,430 matched target firms constitute the main sample used in this study.

Table 2.1 displays the composition of the sample across time and describes the basic characteristics of these matched deals. The time period 1981-2002 covers two merger waves. The number of transactions begins to increase in the 1980s, peaks in the late 1980s, and declines in the early 1990s, before picking up again toward the end of the sample period. The deal value for the sample is quite large due to sample restrictions (publicly-listed target operating plants in the manufacturing sector), averaging about 950 million dollars. The average three-day announcement period abnormal return for target firms is fairly stable, at about $25 \%$ throughout the sample period. A little more than half of these target firms (770) are acquired by another publicly-listed firm with information available from the CRSP. On average, the sample mean of the three-day announcement abnormal return for the acquiring firm is around zero. These figures buttress the well-established finding that mergers clearly benefit target shareholders while, on average, the acquiring firm's shareholder do not lose. The median value of the weighted sum of the announcement returns for target and acquirer combined is about $3.2 \%$. This seems to suggest that these mergers indeed create value to shareholders.

\subsubsection{Matching mergers to census establishment data}

Plant-level information comes from ASM and CMF. These databases include information on total value of shipments, expenditures on intermediate and primary inputs, and other input measures such as materials, energy, and electricity costs. They also provide detailed information on wage and employment which are covered only sparsely in COMPUSTAT. The ASM and CMF database also circumvent the problem with accounting data which are affected by managerial decisions especially after a merger (Houston, James, and Ryngaert, 2001). The economic census takes place in years ending with "2" and "7", and covers approximately 350,000 manufacturing plants each time. The ASM typically samples about 50,000 plants in non-census years. Plants with more than 250 employees and plants that

\footnotetext{
${ }^{6}$ Previous studies including Maksimovic and Phillips (2001) and Schoar (2002) both use Longitudinal Research Database (LRD). Census no longer maintains LRD, but LRD is drawn from ASM and CMF.
} 
are part of very large firms are included by sample design. Some 40,000 other plants are selected with probability proportional to a composite measure of their size. Once a plant is surveyed, the ASM continues surveying this plant to form a five-year panel.

Once I identify a target firm, I use the firm-plant link to identify all of the plants this target firm owns one year prior to a merger. Plants surveyed by the Census Bureau have a permanent establishment identifier (LBDNUM), which remains invariant to ownership changes. This allows me to follow the exact same plants before and after the takeovers. I choose a three-year window, centered around the year when the merger is completed, to track the dynamics of the target plants. ${ }^{7}$ I provide more details about how the sample is constructed in Appendix B.

\subsubsection{Framework and variables}

In this section, I sketch a simple Cobb-Douglas production function to describe the framework and variables used in later estimations. Assume that a plant uses three factors, capital, labor, and material to produce output $Y$ :

$$
Y=A K^{\alpha} L^{\beta} M^{\gamma}
$$

where $Y$ denotes the dollar value of the output; $A$ denotes a constant term measuring the efficiency with which the plant uses its inputs in production (total factor productivity); $L$ denotes labor; $K$ denotes capital; and $M$ denotes material cost.

Let $W$ denote total payroll, which equals the product of the number of employees and their average annual wage, and $I$ denote capital expenditure, which equals changes in capital stock. The plant's before-tax cash flow from operations can be expressed as:

$$
\Pi=Y-W-I-M
$$

This cash flow variable differs from a typical cash flow measure because the data do not measure firm-level costs, such as interest expenses, advertising, and research and develop-

\footnotetext{
${ }^{7}$ For instance, Schoar (2002) chooses a three-year window.
} 
ment. Changes in operating cash flow, then, can be expressed as a function of pre- and post-takeover changes in productivity $\Delta A$; total payroll $\Delta W$; capital expenditures $\Delta I$; and material costs $\Delta M$ :

$$
\Delta \Pi=f(\Delta A, \Delta W, \Delta I, \Delta M)
$$

Assuming that merger announcement abnormal returns capitalize the future cash flow gains or losses as in Equation (2.3) by a proper discount factor $r$, I can therefore link changes in production primitives to changes in the market value of the firm. Specifically, I use Equation (2.4) to test whether changes in productivity and payroll explain changes in announcement returns, denoted as $\Delta V$.

$$
\begin{aligned}
& \text { Assuming that } \Delta V \sim \frac{\Delta \Pi}{r} \text { then, } \\
& \Delta V=f(\Delta A, \Delta W, \Delta I, \Delta M)+\epsilon
\end{aligned}
$$

Total factor productivity (TFP) is used to measure the plant's overall efficiency. I follow Lichtenberg (1992) and Bertrand and Mullainathan (2003) by estimating the following ordinary least squares (OLS) regression separately for each three-digit standard industrial classification (SIC) industry and for each year. The estimation residual term $\epsilon$ is therefore the TFP measure.

$$
\log \left(\text { Output }_{i}\right)=\alpha+\beta_{1} \log \left(\text { Payroll }_{i}\right)+\beta_{2} \log \left(\text { Capital }_{i}\right)+\beta_{3} \log \left(\text { Material }_{i}\right)+\epsilon_{i}
$$

where $i$ indexes plants; Output is measured by the total value of shipments, deflated by industry-level price index; Payroll is total salaries and wages; ${ }^{8}$ and Capital is the value of the capital stock at the beginning of the year. The ASM stopped surveying plants' capital stocks in 1988. For years subsequent to 1988, I compute capital stock by taking the previous census year's capital stock, adding up reported capital expenditures year by year, adjusted for the industry-wide investment deflators in the NBER-CES Productivity

\footnotetext{
${ }^{8}$ Payroll can also proxy for the quality of the work force. The results are unaffected if I use the total number of workers or plant hours.
} 
Database. $^{9}$ Material is the sum of the cost of materials, intermediate goods, energy, and electricity. TFP, the residual from the above estimation, compares the actual amount of output a plant produces with a predicted amount of output. The predicted output is what the plant is expected to produce given the amount of inputs it uses. Because coefficients on capital, labor, and material inputs vary by industry and year, this specification allows for different factor intensities in different industries. The TFP can be interpreted as the efficiency measure of a plant relative to other plants in that same industry in a given year.

Because the estimation of TFP measure requires a particular functional form, I also examine two additional measures of performance: profit margin (used in Maksimovic, Phillips, and Prabhala, 2010) and return to capital (used in Bertrand and Mullainathan, 2003). I divide the gross profit by the value of shipments to construct profit margin and by capital stock to derive return to capital. The gross profit is calculated as the value of shipments net of total payroll and material costs.

\subsubsection{Descriptive statistics}

Table 2.2 reports summary statistics for several key variables for the target firms and plants across seven years around the merger. The top panel presents the firm-level characteristics. A substantial sample attrition can be seen from the second column of the table. For instance, for the year immediately prior to the merger, denoted as T-1, I am able to match 1,430 target firms; however, only 1,305 of these firms exist the year when the merger is completed $(\mathrm{T})$ and 1,275 exist one year after that $(\mathrm{T}+1)$. This means that for 155 mergers, I cannot find any plant left in ASM/CMF at $\mathrm{T}+1$ that was originally owned by the target firm. The plant counts shown in column 2 in the bottom panel reflect this attrition. For example, of all 11,129 plants in T-1, less than $70 \%$ remain in the sample three years after the merger. On average, the acquired firms own about 8 plants prior to the merger and a little less than 7 three years after being acquired. This sample attrition confirms what Maksimovic, Phillips, and Prabhala (2010) find: Acquirers close many acquired plants within three years of acquisition.

Mean and standard deviation for the number of employees and value of output are

\footnotetext{
${ }^{9}$ Available at http://www.nber.org/nberces/
} 
also reported. Two opposing trends can be observed in employment and output levels. While the employment level gradually declines from $\mathrm{T}-3$ to $\mathrm{T}+3$, output experiences a steady increase during the same period, both at the firm and the plant level, which seems to suggest that labor productivity is rising. The sample mean of total factor productivity peaks at $\mathrm{T}-3$, but deteriorates in the three-year span until reaching the trough at $\mathrm{T}$. It then improves from $\mathrm{T}+1$ to $\mathrm{T}+2$, although the highest post-takeover level $\mathrm{T}+2$ is still slightly lower than T-3. This trend of productivity changes is consistent with Yang's (2008) finding that deterioration in productivity precipitates asset sales.

\subsubsection{Control group}

The first goal of this paper is to estimate the effect of takeovers on target plants' productive efficiency. Acquirers do not choose target firms at random, which leads to a selection bias problem. Changes between pre-merger and post-merger depend on a variety of economy and/or industry factors such technology/demand shocks, or on a continuation of firm-specific performance trend. When a target firm experiences a $5 \%$ productivity gain post-takeover, the interpretation depends on whether comparable firms grow by $3 \%$ or shrink by $10 \%$ during the same period. Therefore, it is important to select a control group close to the counterfactuals as benchmarks. My approach here is to choose a group of comparable plants for each target plant based on industry, size, and productivity one year prior to the takeover year. Once I identify the control plants, I use the permanent plant identifier to follow them before and after the merger year the same way that I track the "actual" target plants. The procedure I use is the following:

(1) I begin with all plants available in ASM/CMF and create three equally-sized groups according to the total number of employees (large, medium, and small plants) within each three-digit SIC industry.

(2) In the year immediately before the takeover (T-1), I sort TFP within each SIC-size cell. From the pool of plants that are not acquired the following year, I retain two plants immediately above and two immediately below in TFP than a target plant. By construction, each target plant has at most four control plants.

(3) After identifying all the control plants at T-1, I follow these control plants backward 
at $\mathrm{T}-3$ and $\mathrm{T}-2$, and forward at $\mathrm{T}, \mathrm{T}+1, \mathrm{~T}+2$, and $\mathrm{T}+3$.

Several observations lead me to adopt the above dimension-by-dimension matching method when constructing my control group. ${ }^{10}$ I choose to match on two plant-level characteristics (size and productivity) because later I focus on plant-level productivity and related outcomes. I first match on three-digit SIC industry. Mergers are clustered in industries undergoing exogenous shocks (Mitchell and Mulherin, 1996); thus, the industry-year distribution of the target firms is not random. It is more useful to compare productivity levels within a given industry. Previous studies on post-merger performance often choose industry median for convenient reasons. Harford (2005), however, discounts the validity of this approach. He asserts that due to changes an industry is undergoing and the endogeneity of the choice to merge, the contemporaneous performance of industry median firm is a problematic proxy. I next match plants by size. A plant chooses an optimal size given its productivity; hence, productivity distributions depend on size. I last select control plants that are closest to a target plant in terms of TFP within each SIC-size cell. This is similar to the spirit of Barber and Lyon (1996) on constructing control firms based on comparable pre-event performance. Matching the productivity level ${ }^{11}$ immediately before the merger allows me to compare productivity outcomes for targets relative to a group of most-similar non-target counterparts. This way, I am able to test hypotheses $\mathbf{H 1}$ versus H1a more stringently. To check the robustness of the results, In Section 2.4.4, I also experiment with another group of control plants matched by industry, age, and size. In Section 2.4.5, I use unsuccessful mergers as counterfactuals for how the successful takeovers would have affected productivity thereafter.

\footnotetext{
${ }^{10} \mathrm{An}$ alternative is to use propensity score matching. One issue is that model fit for target selection is poor. Jensen and Ruback (1983, p. 29) stated that "it is difficult, if not impossible, for the market to identify future target firms." See Li and Prabhala (2007) for a detailed treatment of the matching methods when the first stage model fit is poor.

${ }^{11} \mathrm{I}$ run a simple regression $\mathrm{TFP}_{\mathrm{T}-1}-\mathrm{TFP}_{\mathrm{T}-3}=\alpha+\beta$ Target + Industry $\mathrm{FE}+$ Year $\mathrm{FE}+\epsilon$ and find that $\beta$ is statistically indistinguishable from zero. This means that pre-takeover TFP growth was not systematically higher for target plants, thus dispelling the concern that pre-existing trends in TFP driving the results.
} 


\section{$2.4 \quad$ Real effects of takeovers}

\subsubsection{Effects on productive efficiency}

To compare the productivity outcomes of target plants relative to controls subsequent to a takeover, I perform a differences-in-differences analysis for target and control plants in an unbalanced six-year panel: ${ }^{12}$

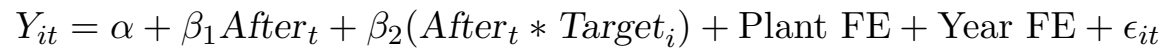

In the above equation, the dependent variable $\mathrm{Y}$ is either TFP, profit margin, or return to capital. After is a dummy variable equal to one for $\mathrm{T}+1, \mathrm{~T}+2$, and $\mathrm{T}+3$ and zero otherwise. Target is a dummy variable that equals one if the target plant's parent firm is acquired at T and zero for control plants. I also use plant size, measured by the total number of employees, as a control variable in some specifications as a robustness check. I only include plants that have at least one observation both before and after the event in the analysis. The above research design is similar to a program evaluation regression labor economists often use. The target plants belong to the "treatment" group; the comparable plants not acquired belong to the "control" group; and the "treatment" event is a "takeover." In essence, I am evaluating the effect of takeover by comparing the before-and-after outcome changes of the treatment group with that of the control group. The coefficient on the interaction term After* Target can be interpreted as the difference in productivity growth for targets relative to control plants between three years before and three years after the merger. The standard errors are clustered at the firm level to allow for group effects within a firm.

The resulting differences-in-differences estimates are presented in Table 2.3. As can be seen from the first two columns, the coefficient $\beta_{2}$ on the interaction term is positive and statistically significant at the $1 \%$ level. This indicates that target plants exhibit higher growth in TFP than similar plants. On average, three years after a merger, plants of the acquired firms achieve a 1.1 percentage points TFP growth premium. This figure is comparable to what the literature has found. For example, Schoar (2002) reports a 0.4\%

\footnotetext{
${ }^{12}$ I drop year T (the merger completion year) to have a more balanced sample for before-and-after analysis.
} 
increase and Maksimovic and Phillips (2001) report a 2\% increase in industry-adjusted TFP three years following a takeover. Columns 3 to 6 of Table 2.3 use Profit margin and Return to capital to examine the impact of the takeover on target plants' profitability. As they turn out, $\beta_{2}$ is positive for both dependent variables, indicating that an increase in productivity also improves a plant's profitability. Profit margin experiences a modest increase of 0.4 percentage points. Return to capital sees a substantial increase; the target plants experience a 25 percentage points higher growth rate relative to controls.

The negative coefficient on After indicates that productivity and profitability of the control plants decline after the target plants are acquired. Two conjectures are offered to explain this finding. First, Mitchell and Mulherin (1996) and Harford (2005) find that merger and restructuring activities clusters within industries in response to major deregulation or technological shocks. Such shocks might lead to worsening performance for plants that do not react accordingly. Second, TFP measures a plant's efficiency relative to its industry peers. If target plants experience improvements in TFP, controls plants in the same industry are more likely to experience performance declines due to competitive pressures.

\subsubsection{Effects on outputs and inputs}

I next explore the detailed mechanisms through which the acquiring firms improve the target plants' TFP. I do so by breaking down TFP into output and input components and estimate the impact of takeovers on these components separately within the same differences-in-differences framework.

Table 2.4 reports the estimation results. All the dependent variables shown are in logarithms. In the top panel, the coefficients on the interaction term are negative and statistically significant for all outcome variables except for output. These results suggest that, post-takeover, target plants produce $0.2 \%$ less output than the controls, but such a difference is statistically indistinguishable from zero. Target plants' investments, as measured by capital expenditures, experience steep declines. Three years following a takeover, a target plant's capital expenditures are about $13 \%$ less than those of controls. These cutbacks can potentially improve productive efficiency for two reasons. First, merging firms can eliminate duplicate investments and create a more efficient internal capital market. Second, previous 
investments may be wasted on unprofitable projects that destroy firm value. These two aspects give the acquiring firms an opportunity to scale back capital expenditures while enhancing efficiency. The material costs dip by $0.9 \%$ in comparison to the control group. Column 3 and 4 report results on wage and employment changes. Average annual wage per worker drops by about $0.5 \%$ and employment level by about $2.3 \%$ more than those of the controls. This finding is in disagreement with the hope that the acquiring firms could share some of the productivity gains with their new employees. ${ }^{13}$ Instead, target firm's employees are adversely affected by the takeovers.

I also look at wage and employment outcomes separately for two groups of workers: production-workers and non-production workers. Note that non-production workers in my context are those who work inside a plant. I do not have information regarding nonproduction workers employed at the headquarters or other non-manufacturing establishments such as sales or distribution centers. The real effects on non-production workers, therefore, are probably under-estimated. As seen in the bottom panel of Table 2.4, while average wages for the two groups experience minimal declines, the reduction in jobs is greater in target plants, especially among non-production workers. On average, production workers are cut by about $1 \%$ more while non-production workers are cut by almost $5 \%$ more compared with controls. This finding is consistent with Jensen and Ruback's (1983) view that the market for corporate control is an important component of the managerial labor market. Takeovers create competition for the right to manage resources and achieve efficiency by replacing the target firms' management teams.

The above results show that TFP improvements result from the acquiring firm's more efficient use of various production inputs. Post-takeover, target plants are able to produce the same level of output relative to control plants, but do so with less investment and material, lower wages, and fewer workers. These results offer support for $\mathbf{H 2}$, that is, acquirers improve targets' productive efficiency through restructuring and downsizing.

\footnotetext{
${ }^{13}$ For instance, Schoar (2002) shows that diversified firms have higher productivity but lower equity value because they dissipate rents by offering higher wages.
} 


\subsubsection{Effects on plant closure}

The above estimations rely on information from continuing plants. The target firm's overall efficiency can be improved upon mainly through two channels. First, the acquiring firms can revamp existing plants' operations to make them perform better. Second, they can selectively shut down underperforming plants. To shed light on this selection channel, I compare the plant exit probability between target plants and control plants each year at $\mathrm{T}$, $\mathrm{T}+1, \mathrm{~T}+2, \mathrm{~T}+3$, and then cumulatively from $\mathrm{T}$ to $\mathrm{T}+3$. Plants may exit the ASM sample over time, however, through panel rotation. To accurately characterize plant death, I draw information from the Longitudinal Business Database (LBD), also maintained at the Census Bureau. The LBD covers all U.S. establishments and firms with at least one paid employee from 1976 to 2005. It is constructed from the Business Register and enhanced with various survey data collections. ${ }^{14}$ In recent years, it has contained more than 6 million establishment records and almost 5 million firm records per year. The LBD contains basic establishment level information including payroll, employment, and first/last year of operation. I use the LBDNUM to match ASM/CMF plants with establishments in LBD to obtain their last year of operation. I code the exit year for all the target and control plants at $\mathrm{T}-1$, and define an indicator variable that equals one if the last year of operation of that particular plant is recorded at $\mathrm{T}, \mathrm{T}+1, \mathrm{~T}+2$, or $\mathrm{T}+3$ and zero otherwise. For example, in 1987, a plant that was to be acquired in 1988, had the last year recoded in LBD as 1990, then the exit dummy variable equals one for period $\mathrm{T}+2$.

I estimate an exit probability model for a pooled sample of the target and control plants at $\mathrm{T}, \mathrm{T}+1, \mathrm{~T}+2$, and $\mathrm{T}+3$, respectively, and then cumulatively from $\mathrm{T}$ to $\mathrm{T}+3$. I control for a plant's initial size and TFP as well as industry and year fixed effects:

$$
\operatorname{EXIT}_{i t}=\alpha+\beta_{1} \text { Target }_{i}+\beta_{2} \text { TFP }_{i}+\beta_{3}\left(\text { TFP }^{*} \text { Target }_{i}\right)+\text { Industry FE }+ \text { Year FE }+\epsilon_{i t}
$$

Due to the presence of a large number of fixed effects, I mainly use linear probability model to estimate Equation (2.7) but use probit model to estimate the cumulative exit probability between $\mathrm{T}$ and $\mathrm{T}+3$. Results in Table 2.5 show that the target plants are

\footnotetext{
${ }^{14}$ See Jarmin and Miranda (2002) for a detailed description of the LBD.
} 
more likely than controls to be shut down each year following the merger. The coefficient on Target captures the difference in exit probability between a target plant and a control plant. At the year when the merger is completed, a target plant is 0.5 percentage points more likely to cease operation. This difference jumps to 2.2 in the first two years and then drops to 1.6 percentage points the third year following the takeover. The last column reports the marginal effects from a probit model. Cumulatively, three years following a takeover, a target plant is 6.9 percentage points more likely to be close than control plants. Not surprisingly, smaller plants and plants with lower productivity are more likely to be shut down.

To examine further whether the acquiring firms are more likely to close the less productive plants of acquired firms, I interact the dummy variable Target with TFP. Except for year $\mathrm{T}+3$, the coefficient on this interaction term is negative and statistically significant. This implies that acquiring firms are not only more aggressive in shutting down plants, but also in shutting down inefficient plants. My results complement the conclusions in Maksimovic, Phillips, and Prabhala (2010) who show that acquirers tend to discard the target's assets in their peripheral divisions. Here, I show that acquirers shed less-efficient target plants more expediently.

As one can see from results in Section 4.2 and Section 4.3, target plants undergo more intense restructuring than otherwise-similar plants. The acquiring firm restructures the target by cutting back investments and labor within continuing plants and by shutting down more inefficient plants. Therefore, $\mathbf{H 2}$ is supported: The acquiring firm achieves productive efficiency improvements through restructuring the target firm. The restructuring activities include employee layoffs, wage reductions, investment cutbacks, and plant closures.

\subsubsection{Robustness checks}

In this section, I check the robustness of the above results by performing two additional tests. First, I use a different control sample to mitigate the concern that the above results are an artifact of a particular control sample. Second, I utilize a small sample of mergers that are ultimately withdrawn by acquirers to conduct a placebo test. 


\subsubsection{A different control group}

I construct a different sample of control plants by matching on industry, age cohorts, and total number of employees pre-takeover following Davis et al. (2008). Specifically, I create three equally-sized age groups (young, middle-aged, and old) within each three-digit SIC industry. In the year prior to the takeover, I sort the total number of employees with each SIC-age cell and retain two plants immediately larger and two immediately smaller than the targeted plant to form my control groups. The number of observations in this alternate control group is slightly greater than the previous control sample because more values are missing for TFP than for the total number of employees.

I perform the same differences-in-differences estimations using this new group of control plants. Results in Table 2.6 are generally consistent with those shown in Table 2.3. The TFP growth premium of target plants over this new sample of control plants is about 1 percentage points, compared with the 1.1 percentage points in Table 2.3 ; Profit margin grows by onetenth of a percentage point faster than the controls, but this figure is not significantly different from zero at a conventional statistical level; Return to capital undergoes substantial improvement by about 17 percentage points, compared to the point estimate of 25 in Table 2.3. The results for other variables in Table 2.6 are similar to those reported in Table 2.3.

Table 2.7 presents the differences-in-differences estimates for all the output and input components. Similarly, all inputs decline relative to controls. Capital expenditures decline by about $11 \%$ more than the controls; Wage rate drops by nearly $1 \%$ and employment level by about $2 \%$ more than controls. When I break down wage and employment outcomes for production and non-production worker groups, the only variable that drops significantly more relative to the controls is the non-production workers' employment level. As one can see, point estimates and standard errors are very similar between Table 2.4 and Table 2.7. This result confirms that the previous estimates are robust to the control sample selections.

\subsubsection{A placebo test with unsuccessful mergers}

Several recent studies (e.g., Pavel and Lu, 2009; Seru, 2010) use mergers that fail to consummate to identify the treatment effect of takeovers. I follow their approach and identify 
236 target firms that bidders ultimately withdraw from acquiring. The sample of unsuccessful mergers allows me to perform two tests. First, I use these unsuccessful targets as counterfactuals for how the successful targets would have affected productivity after mergers. In particular, I perform a differences-in-differences regression using these unsuccessful target firms as a new control sample. The results (unreported) show that relative to these unsuccessful targets, target plants exhibit a 1.5 percentage points gain in TFP post-takeover. In addition, I conduct a "placebo" test to examine whether these unsuccessful takeovers improve their potential target plants' TFP. The results (unreported) show that unsuccessful takeovers fail to increase their potential target plants' productivity relative to comparable control plants. This finding further supports that takeover improve productivity through the actual change of ownership rather than potential threats by announcements.

In summary, these results consistently show that target plants experience about 1 to 1.5 percentage points net productivity gains over control plants. Capital expenditures experience significant decline, by about 10 to $12 \%$, compared with controls. Employees seem to fare worse after takeovers. Average wage and employment are lowered by about 1 to $2 \%$ relative to controls, respectively. The employment cuts are mostly concentrated among non-production workers whereas production workers are largely unaffected.

\subsubsection{Acquirers' incumbent plants}

While the focus of this paper is target plants after a takeover, a related question is how the acquisition affects acquirers' incumbent plant. Only a small portion of the acquiring firms can be matched to ASM/CMF. Of the 1,430 targeted firms, 770 of them are acquired by another U.S. publicly-listed firm. Among these acquiring firms, only less than 500 of them can be matched to ASM/CMF. Some of these acquiring firms are repeated acquirers within a few years, which creates difficulty for me to assign "before" and "after" based on an acquisition event. Solely examining first-time acquirers or acquisitions made some distant apart over time might not provide a complete picture of how acquisitions affect the acquiring firms' incumbent plants. Nevertheless, based on a restricted sample, I find that acquisitions seem to have negligible effects on the acquirers' incumbent plants, either on productivity or on various types of inputs. I do not report the results here in order to 
conserve space.

\subsection{Determinants of announcement returns}

The above results show that target plants exhibit net improvements in total factor productivity and net losses in wages and employment. In this section, I analyze the relation between what happens within the target firm and what happens in the stock market when the merger is announced. In particular, I explore the cross-sectional differences in merger announcement returns from the perspective of the target firm's gains in productivity and losses in wages and employment. To pursue this, I augment the standard regressions of announcement returns with the target firm's change in TFP and payroll between T-1 and $\mathrm{T}+1$. The specification is as follows:

$$
\text { Combined } \mathrm{CAR}_{(-1,+1)}=\alpha+\beta_{1} \Delta \mathrm{TFP}+\beta_{2} \Delta \text { Payroll }+X \gamma+\epsilon
$$

In Equation (2.8), the dependent variable is the three-day combined cumulative abnormal return (CAR) for the target and the acquiring firm. CAR is estimated using a market model estimated over the $(-205,-6)$ interval. Combined CAR is calculated as the equity weighted sum of target CAR and acquirer CAR following the method suggested by Bradley, Desai, and Kim (1988). The combined announcement returns measure the total surplus to shareholders generated by the merger. Later, I also consider offer premiums to the target and the returns to acquirer separately using the same specification.

$\triangle \mathrm{TFP}$ is calculated by subtracting the target firm's TFP at $\mathrm{T}-1$ from TFP at $\mathrm{T}+1$. $\Delta$ Payroll measures the target firm's percentage change in total payroll. I calculate $\Delta$ Payroll by subtracting the logarithm of Payroll at $\mathrm{T}-1$ from the logarithm of Payroll at $\mathrm{T}+1$. The firm's TFP and Payroll are formed as the employment-weighted average of all the active plants' TFP and payroll, respectively. This method of construction is designed to capture two aspects of changes: The improvement effects over the continuing plants and the selection effects of closing failing plants. Note that only target firms with at least one plant active at both $\mathrm{T}-1$ and $\mathrm{T}+1$ are included in the sample. Table 2.8 reports the mean, standard deviation, and pairwise correlation for some variables of interest. Among the 1,430 merger 
transactions, 1,226 target firms have non-missing values on $\triangle \mathrm{TFP}$ and $\Delta$ Payroll; and 659 target firms are acquired by another publicly-listed firms with information available from CRSP. $\triangle \mathrm{TFP}$ and $\triangle$ Payroll are negatively correlated with each other. According to the pairwise correlation, $\triangle \mathrm{TFP}$ is positively correlated with combined CAR and offer premiums but negatively correlated with acquirer CAR, while $\triangle$ Payroll is positively correlated with all three return variables.

Several choices of variables are worthy of further explanation. First of all, one would also want to incorporate changes for the plants of the acquiring firm into consideration. I focus solely on changes to the target firm's plants for two reasons. On the one hand, prior literature and my results both reveal that target firm's plants undergo much more restructuring than the acquiring firms' incumbent plants following an acquisition. The unreported results referenced in Section 2.4.5 show that the acquiring firm's incumbents plant are generally unaffected by the acquisition. On the other, as also stated in section 2.4.5, only a small subset of the targets are acquired by another firm that can be matched to $\mathrm{ASM} / \mathrm{CMF}$, and CRSP and many of these matches are repeated acquirers (within a few years). Incorporating the changes to the acquiring firm's incumbent plants would reduce the sample too much. Second, I only consider the changes that occurred between T-1 and $\mathrm{T}+1$. This is likely conservative because some of the changes in productivity and payroll may appear later. Yet changes between these three years still capture much of the action due to the merger. Last, the announcement returns reflect expectations of future economic gains or losses; hence, all the analysis hinges on the assumption that the market expectation is eventually realized.

To explore other determinants of announcement returns, I mainly consider two groups of factors: Target/acquirer firm characteristics and deal characteristics. The firm characteristics include firm size and the market-to-book ratio. Both variable are measured at the fiscal year prior to the takeover announcement. I also create a relative size measure for the target, calculated as the share of the target firm's market value to the sum of the target and the acquirer's market value, as in Hoberg and Phillips (2010).

Deal characteristics include offer premium, method of payment, target-acquirer industry 
relatedness, and acquirer's listing status ${ }^{15}$. I calculate the premium as the ratio of deal value to the target's market value 30 days before the merger announcement. I create two variables All Cash and Some Stock to distinguish between mergers financed by cash versus stock. I measure target-acquirer relatedness using a dummy variable that equals one if the target and the acquirer share the same primary two-digit SIC industry. I also consider the listing status of the acquiring firm. I create an indicator variable Private Acquirer which equals one if the acquiring firm is not publicly-listed, and zero otherwise. A detailed description of the variables is provided in Appendix A.

I estimate Equation (2.8) to test the efficiency creation hypothesis and the employee wealth redistribution hypothesis. The hypothesis that the total gains to shareholders reflect efficiency improvements implies $\beta_{1}$ is positive. Alternatively, if the total gains represent wealth redistribution from the target firm's employees, $\beta_{2}$ should be negative.

\subsubsection{Effects of changes in productivity and payroll on combined CAR}

Table 2.9 reports estimates from cross-sectional OLS regression of the combined CAR. The first two columns report uni-variate regression results when I only include $\triangle \mathrm{TFP}$ and $\Delta$ Payroll, respectively. Columns 3 to column 5 estimate equation (2.8) with full set of controls. The results are strengthened when I include other determinants of announcement returns. The coefficients on $\triangle \mathrm{TFP}$ are positive and statistically significant, which suggests that improvements in productivity are associated with higher combined CAR. In terms of economic significance, the coefficient of 0.039 in column 3 implies that acquiring a target firm with $\triangle \mathrm{TFP}$ at the 25 th percentile yields 1 percentage points lower combined announcement returns than acquiring a target with $\triangle \mathrm{TFP}$ at the 75 th percentile in my sample. This amount is considerable given that the sample median of the combined CAR is less than $3.5 \%$. Results in columns 2 and 4 show that changes in the target firm's total payroll are not significantly related to the combined CAR. When I control for both $\Delta \mathrm{TFP}$ and $\Delta$ Payroll in columns 5 , the results on $\triangle \mathrm{TFP}$ remain similar to those in column 3 , and the coefficients on $\Delta$ Payroll are again statistically indistinguishable from zero. These results provide support

\footnotetext{
${ }^{15}$ Many papers also include deal attitude (Schwert, 2000), but in SDC only $5 \%$ of deals have an attitude classfied as "hostile".
} 
for $\mathbf{H 3}$ rather than $\mathbf{H 4}$ : improvements in productivity rather than wealth redistribution from employees are associated with higher announcement returns to the combined firm. In columns 6 , I further add the interaction terms of relative size of target (RelaSize) with $\Delta \mathrm{TFP}$ and $\triangle$ Payroll. The idea is that some of the improvements in TFP or labor costs savings in the target firm might not affect the combined returns because the targets are very small relative to the acquiring firm. The results show that both the coefficients on RelaSize and the interaction terms between $\triangle \mathrm{TFP}$ and RelaSize are positive and statistically significant at the $1 \%$ level. This indicates that the positive effect of $\Delta \mathrm{TFP}$ on combined CAR is more pronounced when target is relatively larger compared with acquirer. Ceteris paribus, if the target's pre-takeover market value is half of the acquirer's, an acquisition of a target firm with $\triangle \mathrm{TFP}$ at the 25 th percentile yields about 2.5 percentage points lower combined announcement returns than a target with $\triangle \mathrm{TFP}$ at the 75 th percentile. Also worth noting is the fact that the $\mathrm{R}^{2}$ in these two specifications increases from about 0.10 to 0.32 in the last column.

Results on other control variables are generally consistent with findings in prior literature. Related mergers generate about 2 percentage points higher combined returns than unrelated mergers. If the acquirer uses some stocks to pay for the target, the combined returns are lowered by about 3 to 4 percentage points. Large acquiring firms tend to make value-destroying acquisitions, as shown in Moeller, Schlingemann, and Stulz (2004, 2005). Prior studies find that the Tobin's Q (the close surrogate of market-to-book ratio) has an ambiguous effect on merging firms' announcement returns. For instance, Lang, Stulz, and Walkling (1989) and Servaes (1991) find that combined CAR are positively related to the acquirer's Q, while Moeller, Schlingemann, and Stulz (2004) show the contrary. In my sample, I find that the acquirers with higher market-to-book ratio are associated with negative announcement returns for the combined firm.

\subsubsection{Effects of changes in productivity and payroll on premium}

I next estimate the same regression of offer premium on improvements in TFP to test H5, that is, whether offer premiums can be explained by post-takeover productivity improvements. The results are presented in Table 2.10. The coefficient on $\Delta$ TFP is positive 
and statistically significant, which suggests that the acquiring firm does pay a higher premium to a target with greater post-takeover improvements in productivity. Point estimates on $\triangle$ TFP range from 0.25 to 0.38 depending on different sets of control variables. To interpret the economic magnitude, other things being equal, a target at the 25th percentile of $\triangle \mathrm{TFP}$ receives about 6 to 9.5 percentage points lower premium than a target at the 75th percentile. Such a change is substantial considering that the median value of the offer premium in my sample is about $50 \%$. The statistical insignificance of the coefficient on $\Delta$ Payroll suggests that changes in payroll do not explain offer premiums. Hence, $\mathbf{H 5}$ is supported: Cross-sectionally, target firms with greater post-takeover improvements in productivity receive higher offer premiums from the acquirer. These results are consistent with insights from Rhodes-Kropf and Robinson (2008) who posit that the bargaining outcome of merger depends on merging firms' expected gains from waiting. To the extent that targets with greater productivity improvements are also expected to gain more from merging with other firms, they are in a stronger bargain position to demand for higher premiums from acquirers. Column 6 in Table 2.10 reports results when I control for the interaction terms of target's relative size with changes in productivity and payroll. In contrast to the results shown in Table 2.9 , the effect of $\Delta \mathrm{TFP}$ on offer premium is not contingent upon target's relative size.

Baker, Pan, and Wurgler (2010) recently advance a "reference point" explanation arguing that acquirer's offer prices are benchmarked against target's previous 52-week highest price. I confirm their findings and show that target's 52-W High Price has a positive and statistically significant effect on offer premiums. Much of the explanatory power comes from a few variables related to the deal's characteristics. A target that shares the same primary industry with the acquiring firm receives a 30 percentage points higher premium from an acquirer; the target is willing to trade for a significantly lower premium for cash payment. In untabulated results, I show that a private acquiring firm pays a lower premium than a public acquirer, Consistent with the finding in Bargeon, Schlingemann, Stulz, and Zutter (2008). Regression results using target's CAR are generally similar to results on offer premiums ${ }^{16}$. For space considerations, I do not report those results here.

\footnotetext{
${ }^{16}$ Schwert (1996) provides insights on the relation between premiums and target CAR.
} 


\subsubsection{Effects of changes in productivity and payroll on acquirer CAR}

Last, I look at the acquiring firm's announcement returns. The results are reported in Table 2.11. $\triangle$ TFP has a positive effect on the acquirer's CAR although the point estimate is not statistically significant at a conventional level. In fact, very few regressors have significant explanatory power for the acquirer's CAR. The two exceptions are variables for stock mergers and acquirer's size. Both variables are negatively associated with acquirer's CAR, which are consistent with the stylized facts documented in Moeller, Schlingemann, and Stulz (2004, 2005). Mergers undertaken by large acquirer and mergers financed using stocks are generally associated with negative announcement returns for acquiring firms.

Except for acquirer size and method of payments, prior literature has yet to find any variables that can explain variations in acquirer's announcement returns. Houston, James, and Ryngaert (2001) conjecture that improvements over the target firms might not lead to discernable gains to the acquiring firms themselves because acquirers are usually much larger than targets. In the last column, I control for the interaction terms between target's relative size and $\triangle \mathrm{TFP}$ and $\triangle$ Payroll. Results show that Relasize* $\Delta \mathrm{TFP}$ is positively associated with acquirer CAR and Relasize* $\Delta$ Payroll is not significantly related with acquirer CAR. The point estimate on Relasize* $\Delta \mathrm{TFP}$ is 0.116 and is statistically significant at the $5 \%$ level. It implies that improvements in target's productivity exert a positive and significant effect only when target is relatively larger compared with acquirer. Other things equal, if the target is half the size of the acquirer, acquiring a target at the 25 th percentile of $\triangle \mathrm{TFP}$ generates about 2 percentage points higher than acquiring a target at the 75 th percentile.

The magnitude of the increase is economically significant as the sample median of the acquirer CAR is merely zero. Remember that I previously show that Relasize* $\Delta$ TFP has a positive effect on combined CAR but no effect on offer premiums. This finding reveals that the effect of $\triangle \mathrm{TFP}$ on combined CAR is mainly manifested through $\triangle \mathrm{TFP}$ 's effect on acquirer CAR. This finding further supports that the announcement returns are driven by post-takeover improvements in target's productivity. 


\subsubsection{Further tests of employee wealth redistribution hypothesis}

Though prior results consistently show that labor cost cuts in employees' total payroll are not associated with merging firms' announcement returns, it is still premature to dismiss wealth redistribution from employees as a possible explanation for shareholder gains. The empirical challenge is that wage and employment reductions are probably part of the productivity-increasing process; therefore, one cannot separately identify the effect of employee redistribution on shareholders value gains. In this section, I conduct two additional tests to disentangle the efficiency creation hypothesis from the employee wealth redistribution hypothesis.

First, I regress dollar value gains to shareholders (based on premiums and combined CAR) on dollar value savings from employee payroll. The results are reported in Table 2.12. The first three columns report results where I use Dollar Premium as measures for gains to the target firm's shareholders. The point estimates of $\Delta$ Dollar Payroll are less than -1 and are statistically significant. The coefficient implies that a $\$ 1$ cut to employee payroll translates to $\$ 1.97$ to $\$ 5.80$ dollar gain to the target firm's shareholders. ${ }^{17}$ This result is partly consistent with the stakeholder view of the firm: Shareholders hold the residual claim value of the firm, whereas the employees receive contractual compensation for their services. Abowd (1989) finds that unexpected increases in collectively bargained labor costs lead to a dollar-for-dollar decrease in a firm's equity values. My finding that the point estimate is greater than one seems to suggest savings from labor costs not only transfer the saved amount but also entail additional value transfers — possibly through productivity gains - to shareholders. Columns 4 through 6 report estimates when I use dollar gains to the combined firm as dependent variables. Point estimates of coefficients on $\Delta$ Dollar Payroll are negative although statistically indistinguishable from zero. However, point estimates on the regressors are fluctuating possibly because both the dependent variables and $\Delta$ Dollar Payroll vary widely from large positive numbers to large negative numbers. On average, a target firm cuts about $\$ 15$ million while gains about $\$ 400$ million in premiums. These numbers indicate that the savings on labor costs can explain at most

\footnotetext{
${ }^{17}$ The dollar gains to shareholders are significantly greater than dollar savings in payroll in absolute amount. This might explain why I do not find significant relation between $\Delta$ Payroll and combined CAR.
} 
a limited extent of wealth gains to shareholders.

Second, I examine the employee wealth redistribution hypothesis from the perspective of changes in fringe benefits. Employees' fringe benefits include pension plans, health insurance, and unemployment benefits etc. Different from Payroll, which is directly factored into construction of the TFP measure (see Equation (2.5)), the costs of fringe benefits are not. I re-estimate the Equation (2.8) adding percentage change in target's cost of fringe benefits $\Delta$ Fringe Benefits. Regression results are reported in columns 1, 3, and 5 of Table 2.13. Point estimates on $\Delta$ Fringe Benefits indicate that changes in the cost of fringe benefits are not associated with combined CAR, offer premium, or the acquirer CAR. Furthermore, a firm's payroll is a product of the average employee wage and the total number of employees. I then investigate whether employee wealth redistribution can arise separately from reductions in wage and/or employment. Employee wealth redistribution can nonetheless occur at individual level (through employee layoff), or at the group level (through wage reduction). Columns 2, 4, and 6 report estimates when I regress announcement returns on $\Delta$ Wage Rate and $\Delta$ Employment. Neither of these two variables, however, are statistically significantly related to the merging firms' announcement returns. These results show that cuts in employees' fringe benefits, average employee wage, and total employment level cannot explain gains to shareholders. Again, these findings do not support the employee wealth redistribution hypothesis.

In summary, these two additional tests provide further evidence that the extent of employee wealth redistribution is relatively small. They reinforce the conclusion that improvements in productivity, rather than wealth redistribution from employees, underpin the wealth gains to the shareholders of the merging firms.

\subsection{Conclusions}

In this paper, I attempt to uncover the underlying sources of gains from takeovers. I tackle this question in two steps. First, by examining changes to output, input, and plant closures after a takeover, I identify the detailed channels through which the acquiring firm enhances the target firm's productivity. Second, by establishing a direct relation between 
a target firm's underlying gains and losses and takeover announcement stock returns, I provide some micro-foundations to understand the stock market revaluation of the merging firms.

I analyze a sample of 1,430 mergers using plant-level data from the U.S. Census Bureau. To evaluate the real effects of takeovers, I construct a group of control plants that are comparable to target plants in terms of industry, size, and productivity as benchmarks. Using a differences-in-differences regression approach, I find that target plants exhibit net gains in total factor productivity, profit margin, and return to capital, relative to comparable plants. These improvements are accomplished mainly through two avenues. First, the acquiring firm is able to deploy the resources more efficiently. In particular, while the target plants undergo significant cutbacks in capital expenditure, wages, and employment, the level of output remains largely unaffected, relative to controls. Second, the acquiring firms are more aggressive in shutting down the target plants, especially those that are less efficient.

These micro-level changes help explain the cross-sectional differences in merging firms' announcement returns. I consider the impact of the target firm's gains in productivity and savings in labor costs on announcement returns of the merging firms. I show that improvements in productivity, rather than savings on labor costs, are associated with higher combined announcement return for the target and acquiring firms. The effect of increase in productivity on combined announcement return is statistically robust and economically significant. This evidence provides support for the hypothesis that efficiency creation, rather than wealth redistribution from employees, underlies the total wealth gains to the shareholders.

When I examine the gains to the target and the acquirer separately, I find that the target firms with greater future improvements in productivity receive higher offer premiums from the acquiring firms. Neither improvements in productivity nor savings from labor costs, however, are significantly associated with the acquirer's own announcement returns. Targets' improvements in productivity have a positive acquirers' announcement returns only when the target is relatively large compared with acquirer. It remains an open question why many acquirers lose value upon merger announcement. A detailed examination of this 
question is left for future research.

The potential for wealth redistribution from employees in the target firm has generated considerable controversy in public policy debates over mergers. My results provide strong support for the efficiency-enhancing aspect rather than the wealth redistribution aspect of mergers. Overall, my study shows that takeovers are an efficient mechanism to reallocate productive assets to management that can better use them. This study also highlights the interconnections between product market, labor market, and the stock market, in the context of mergers and acquisitions. 
Table 2.1: Number of Deals and Basic Deal Characteristics

The table describes the basic characteristics of the takeover sample in this study. The sample consists of mergers from the SDC M\&As database in which the announcement date is between 1981 and 2002, the completion date is within 360 days of the announcement, and the target is a publicly-listed firm that can be matched to the ASM/CMF, maintained at U.S. Census Bureau. Column 2 reports the number of mergers completed each year. Column 3 and 4 report the mean and standard deviation of deal value (reported in SDC). Column 5 through 8 report the mean and standard deviation of the three-day Cumulative Abnormal Return (CAR) around deal announcements, for the target and the acquirer, respectively. CAR is estimated using a market model adjusted for CRSP value-weighted market index.

\begin{tabular}{ccrrrrrr}
\hline & & \multicolumn{3}{c}{ Deal Value } & \multicolumn{2}{c}{ Target CAR $_{(-1,+1)}$} & \multicolumn{2}{c}{ Acquirer CAR $_{(-1,+1)}$} \\
\hline Year & $\mathrm{N}$ & \multicolumn{1}{c}{ Mean } & \multicolumn{1}{c}{ SD } & Mean & SD & Mean & SD \\
\hline 1981 & 15 & 322.8 & 457.9 & 0.251 & 0.332 & -0.004 & 0.052 \\
1982 & 19 & 219.4 & 285.8 & 0.162 & 0.148 & -0.013 & 0.047 \\
1983 & 34 & 157.1 & 239.3 & 0.110 & 0.149 & 0.016 & 0.122 \\
1984 & 48 & 285.3 & 415.3 & 0.138 & 0.171 & -0.009 & 0.059 \\
1985 & 60 & 747.6 & 1297.6 & 0.186 & 0.176 & -0.014 & 0.052 \\
1986 & 103 & 524.3 & 1163.8 & 0.167 & 0.177 & 0.004 & 0.051 \\
1987 & 76 & 468.6 & 733.9 & 0.216 & 0.187 & 0.019 & 0.058 \\
1988 & 124 & 504.3 & 1392.5 & 0.228 & 0.235 & -0.009 & 0.087 \\
1989 & 85 & 969.3 & 3662.5 & 0.213 & 0.209 & -0.007 & 0.070 \\
1990 & 53 & 506.4 & 917.9 & 0.272 & 0.269 & -0.020 & 0.047 \\
1991 & 24 & 1178.1 & 2385.8 & 0.345 & 0.385 & 0.018 & 0.087 \\
1992 & 16 & 195.4 & 262.1 & 0.292 & 0.202 & 0.035 & 0.081 \\
1993 & 40 & 312.0 & 666.6 & 0.287 & 0.213 & -0.007 & 0.056 \\
1994 & 42 & 984.9 & 2209.5 & 0.208 & 0.160 & -0.005 & 0.066 \\
1995 & 60 & 790.3 & 1646.6 & 0.224 & 0.177 & -0.012 & 0.058 \\
1996 & 83 & 1053.8 & 2754.4 & 0.226 & 0.237 & -0.001 & 0.069 \\
1997 & 85 & 746.4 & 1625.6 & 0.236 & 0.202 & 0.016 & 0.068 \\
1998 & 126 & 2226.3 & 7936.6 & 0.265 & 0.230 & 0.010 & 0.078 \\
1999 & 128 & 1444.3 & 3009.8 & 0.262 & 0.212 & 0.003 & 0.086 \\
2000 & 112 & 3095.4 & 10260.4 & 0.302 & 0.286 & -0.015 & 0.087 \\
2001 & 62 & 2239.3 & 5782.7 & 0.345 & 0.534 & -0.031 & 0.097 \\
2002 & 35 & 1919.5 & 5049.8 & 0.152 & 0.225 & -0.023 & 0.094 \\
\hline Total & 1430 & 949.6 & 4480.34 & 0.233 & 0.248 & -0.002 & 0.074 \\
\hline
\end{tabular}


Table 2.2: Descriptive Statistics for Target Firm/Plant Output and Employment

The table reports summary statistics for some variables at the target firm and plant level. The sample consists of mergers from the SDC M\&As database in which the announcement date is between 1981 and 2002, the completion date is within 360 days of the announcement, and the target is a publiclylisted firm that can be matched to the ASM/CMF, maintained at U.S. Census Bureau. T is the year when the merger is completed. Output is the total value of shipment, expressed in millions of dollars. Total factor productivity (TFP) is the residual from estimating a log linear Cobb-Douglas production function at the plant level, where one regresses the value of output on total payroll, capital stock, and material cost separately for each 3-digit SIC industry and year. Employment is the total number of employees.

\begin{tabular}{lccccccc}
\hline \multicolumn{7}{c}{ Panel A: Firm level } \\
\hline \multirow{2}{*}{ Timing } & $\mathrm{N}$ & Mean & SD & Mean & SD & Mean & SD \\
\hline $\mathrm{T}-3$ & 1272 & 7.38 & 14.46 & 2729.4 & 6629.7 & 631.5 & 3223.8 \\
$\mathrm{~T}-2$ & 1305 & 7.54 & 15.25 & 2700.5 & 6530.7 & 645.1 & 3277.5 \\
$\mathrm{~T}-1$ & 1430 & 8.09 & 16.21 & 2531.7 & 6276.8 & 635.1 & 3367.6 \\
$\mathrm{~T}$ & 1275 & 7.51 & 15.25 & 2588.6 & 6365.9 & 664.6 & 3065.0 \\
$\mathrm{~T}+1$ & 1228 & 7.44 & 14.87 & 2540.7 & 6221.8 & 673.9 & 2928.2 \\
$\mathrm{~T}+2$ & 1169 & 7.22 & 14.42 & 2539.2 & 6347.1 & 711.2 & 3024.8 \\
$\mathrm{~T}+3$ & 1139 & 6.92 & 13.60 & 2427.7 & 5797.9 & 739.2 & 3139.6 \\
\hline
\end{tabular}

Panel B: Plant level

\begin{tabular}{lccccccc}
\hline & \multicolumn{2}{c}{ TFP } & \multicolumn{2}{c}{ Employment } & \multicolumn{2}{c}{ Output } \\
Timing & $\mathrm{N}$ & Mean & SD & Mean & SD & Mean & SD \\
\hline $\mathrm{T}-3$ & 9045 & 0.039 & 0.33 & 371.9 & 719.9 & 75.9 & 295.7 \\
$\mathrm{~T}-2$ & 9465 & 0.031 & 0.32 & 358.3 & 711.0 & 75.7 & 299.7 \\
$\mathrm{~T}-1$ & 11129 & 0.031 & 0.34 & 315.5 & 671.0 & 70.9 & 301.1 \\
$\mathrm{~T}$ & 9201 & 0.029 & 0.34 & 346.1 & 691.1 & 78.2 & 261.1 \\
$\mathrm{~T}+1$ & 8742 & 0.031 & 0.33 & 343.0 & 684.9 & 80.6 & 258.3 \\
$\mathrm{~T}+2$ & 8129 & 0.039 & 0.35 & 350.0 & 690.9 & 86.6 & 279.8 \\
$\mathrm{~T}+3$ & 7591 & 0.037 & 0.35 & 351.3 & 651.4 & 96.2 & 331.7 \\
\hline
\end{tabular}


Table 2.3: The Effect of Takeovers on Efficiency

The table reports estimates of a plant-level differences-in-differences regression of $Y_{i t}=\alpha+\beta_{1}$ After $_{t}+$ $\beta_{2}\left(\right.$ After $_{t} *$ Target $\left._{i}\right)+$ Plant \& Year FE $+\epsilon_{i t}$. The sample consists of mergers from the SDC M\&As database in which the announcement date is between 1981 and 2002, the completion date is within 360 days of the announcement, and the target is a publicly-listed firm that can be matched to the ASM/CMF, maintained at U.S. Census Bureau. Total factor productivity (TFP) is the residual from estimating a log linear Cobb-Douglas production function at the plant level, where one regresses the value of output on total payroll, capital stock, and material cost separately for each 3-digit SIC and year. Profit margin is the ratio of profit (sales minus material cost and labor cost) to sales. Return to capital is the ratio of profit to capital stock. The data are an unbalanced six-period panel $(\mathrm{T}-3$, $\mathrm{T}-2, \mathrm{~T}-1, \mathrm{~T}+1, \mathrm{~T}+2$, and $\mathrm{T}+3)$ for target plants and control plants. $\mathrm{T}$, the year when the merger is completed, is dropped out from the analysis. After is a dummy variable that equals one for $\mathrm{T}+1$, $\mathrm{T}+2$ and $\mathrm{T}+3$, and zero for $\mathrm{T}-1, \mathrm{~T}-2$ and $\mathrm{T}-3$. Target is a dummy variable that equals one if a plant's parent firm is acquired at year $\mathrm{T}$, and zero if a plant is a control plant. The control sample is constructed by selecting plants that are comparable to target plants in terms of industry, size, and TFP prior to the takeover. Heteroskedastic-robust standard errors clustered at the firm level are in parentheses. The symbols $* * *, * *$, and $*$ indicate statistical significance at the 1,5 , and 10 percent levels, respectively.

\begin{tabular}{lcccccc}
\hline & \multicolumn{2}{c}{ TFP } & \multicolumn{2}{c}{ Profit Margin } & \multicolumn{2}{c}{ Return to Capital } \\
& $(1)$ & $(2)$ & $(3)$ & $(4)$ & $(5)$ & $(6)$ \\
\hline After & $-0.013^{* * *}$ & $-0.013^{* * *}$ & $-0.006^{* * *}$ & $-0.007^{* * *}$ & $-0.111^{* * *}$ & $-0.110^{* * *}$ \\
& $(0.003)$ & $(0.003)$ & $(0.001)$ & $(0.001)$ & $(0.032)$ & $(0.032)$ \\
After*Target & $0.012^{* * *}$ & $0.011^{* * *}$ & 0.004 & $0.004^{* *}$ & $0.253^{* * *}$ & $0.254^{* * *}$ \\
& $(0.004)$ & $(0.004)$ & $(0.003)$ & $(0.002)$ & $(0.048)$ & $(0.048)$ \\
Log(employment) & & $-0.014^{* * *}$ & & $-0.015^{* * *}$ & & 0.043 \\
& & $(0.003)$ & & $(0.002)$ & & $(0.039)$ \\
Constant & $0.051^{* * *}$ & $0.126^{* * *}$ & $0.284^{* * *}$ & $0.365^{* * *}$ & $1.330^{* * *}$ & $1.106^{* * *}$ \\
& $(0.014)$ & $(0.020)$ & $(0.008)$ & $(0.012)$ & $(0.083)$ & $(0.222)$ \\
Plant FE & Yes & Yes & Yes & Yes & Yes & Yes \\
Year FE & Yes & Yes & Yes & Yes & Yes & Yes \\
Observations & 173,505 & 173,505 & 173,505 & 173,505 & 173,505 & 173,505 \\
$\mathrm{R}^{2}$ & 0.53 & 0.53 & 0.58 & 0.58 & 0.39 & 0.40 \\
\hline
\end{tabular}


Table 2.4: The Effect of Takeovers on Outputs and Inputs

The table reports estimates of a plant-level differences-in-differences regression of $\log \left(Y_{i t}\right)=\alpha+$

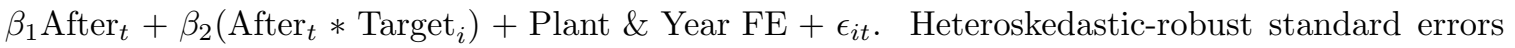
clustered at firm level are in parentheses. The symbols $* * *, * *$, and $*$ indicate statistical significance at the 1,5 , and 10 percent levels, respectively.

\begin{tabular}{|c|c|c|c|c|c|}
\hline & $\begin{array}{l}\text { Output } \\
\text { (1) }\end{array}$ & $\begin{array}{c}\text { Investment } \\
(2)\end{array}$ & $\begin{array}{l}\text { Materials } \\
\text { (3) }\end{array}$ & $\begin{array}{l}\text { Wage } \\
(4)\end{array}$ & $\begin{array}{c}\text { Employment } \\
(5)\end{array}$ \\
\hline After & $\begin{array}{c}-0.023^{* * *} \\
(0.004)\end{array}$ & $\begin{array}{c}-0.101^{* * *} \\
(0.014)\end{array}$ & $\begin{array}{c}-0.017^{* * *} \\
(0.005)\end{array}$ & $\begin{array}{c}0.003 \\
(0.002)\end{array}$ & $\begin{array}{c}-0.013^{* * *} \\
(0.004)\end{array}$ \\
\hline After*Target & $\begin{array}{c}-0.002 \\
(0.006)\end{array}$ & $\begin{array}{c}-0.128^{* * *} \\
(0.029)\end{array}$ & $\begin{array}{r}-0.009^{*} \\
(0.005)\end{array}$ & $\begin{array}{r}-0.005^{*} \\
(0.003)\end{array}$ & $\begin{array}{c}-0.023^{* * *} \\
(0.007)\end{array}$ \\
\hline Log(employment) & $\begin{array}{l}0.802^{* * *} \\
(0.008)\end{array}$ & $\begin{array}{l}1.105^{\text {*** }} \\
(0.019)\end{array}$ & $\begin{array}{l}0.802^{* * *} \\
(0.009)\end{array}$ & $\begin{array}{c}-0.089^{* * *} \\
(0.004)\end{array}$ & \\
\hline Constant & $\begin{array}{l}5.366^{* * *} \\
(0.044)\end{array}$ & $\begin{array}{l}0.066^{* * *} \\
(0.130)\end{array}$ & $\begin{array}{l}4.614^{* * *} \\
(0.052)\end{array}$ & $\begin{array}{l}11.052^{* * *} \\
(0.021)\end{array}$ & $\begin{array}{l}5.238^{* * *} \\
(0.025)\end{array}$ \\
\hline Plant FE & Yes & Yes & Yes & Yes & Yes \\
\hline Year FE & Yes & Yes & Yes & Yes & Yes \\
\hline Observations & 173.505 & 173,505 & 173,505 & 173,505 & 173,505 \\
\hline \multirow[t]{3}{*}{$\mathrm{R}^{2}$} & 0.96 & 0.70 & 0.94 & 0.83 & 0.94 \\
\hline & & \multicolumn{2}{|c|}{ Production Worker } & \multicolumn{2}{|c|}{ Non-production Worker } \\
\hline & & $\begin{array}{l}\text { Wage } \\
(1)\end{array}$ & $\begin{array}{c}\text { Employment } \\
(2)\end{array}$ & $\begin{array}{c}\text { Wage } \\
(3)\end{array}$ & $\begin{array}{c}\text { Employment } \\
\text { (4) }\end{array}$ \\
\hline After & & $\begin{array}{l}0.006^{* * *} \\
(0.002)\end{array}$ & $\begin{array}{c}-0.018^{* * *} \\
(0.004)\end{array}$ & $\begin{array}{r}-0.024^{*} \\
(0.013)\end{array}$ & $\begin{array}{c}-0.001 \\
(0.006)\end{array}$ \\
\hline After*Target & & $\begin{array}{c}-0.002 \\
(0.004)\end{array}$ & $\begin{array}{r}-0.012^{*} \\
(0.007)\end{array}$ & $\begin{array}{c}-0.001 \\
(0.026)\end{array}$ & $\begin{array}{c}-0.048^{* * *} \\
(0.011)\end{array}$ \\
\hline Log(employment) & & $\begin{array}{c}-0.075^{* * *} \\
(0.004)\end{array}$ & & $\begin{array}{l}0.415^{* * *} \\
(0.028)\end{array}$ & \\
\hline Constant & & $\begin{array}{l}10.839^{* * *} \\
(0.023)\end{array}$ & $\begin{array}{l}4.936^{* * *} \\
(0.027)\end{array}$ & $\begin{array}{l}8.508^{* * *} \\
(0.158)\end{array}$ & $\begin{array}{l}3.677^{* * *} \\
(0.034)\end{array}$ \\
\hline Plant FE & & Yes & Yes & Yes & Yes \\
\hline Year FE & & Yes & Yes & Yes & Yes \\
\hline Observations & & 173,505 & 173,505 & 173,505 & 173,505 \\
\hline $\mathrm{R}^{2}$ & & 0.78 & 0.93 & 0.55 & 0.88 \\
\hline
\end{tabular}


Table 2.5: The Effect of Takeovers on Plant Closure

The table reports estimates of a plant-level regression of Exit $i t=\alpha+\beta_{1} \operatorname{Target}_{i}+\beta_{2} \operatorname{TFP}_{i}+\beta_{3}\left(\mathrm{TFP}_{i} *\right.$ Target $\left._{i}\right)+\epsilon_{i t}$, where $\mathrm{t}=\mathrm{T}, \mathrm{T}+1, \mathrm{~T}+2, \mathrm{~T}+3$, and cumulatively from $\mathrm{T}$ to $\mathrm{T}+3$. The sample consists of mergers from the SDC M\&As database in which the announcement date is between 1981 and 2002, the completion date is within 360 days of the announcement, and the target is a publicly-listed firm that can be matched to the ASM/CMF, maintained at U.S. Census Bureau. The dependent variable Exit is a dummy variable that equals one if a plant is closed at time $t$ and zero otherwise. Target is a dummy variable that equals one if the plant's parent firm is acquired at year $\mathrm{T}$ and zero if a plant is a control plant. The control sample is constructed by selecting plants that are comparable to target plants in terms of industry, size, and TFP prior to the takeover. Total factor productivity (TFP) is the residual from estimating a log linear Cobb-Douglas production function at plant level, where one regresses the value of output on total payroll, capital stock, and material cost separately for each 3-digit SIC and year. The regression also controls for industry and year fixed effects as well as the number of employees (in logs). Columns 1 through 5 report OLS regression results and column 6 reports marginal effect from a probit estimation. Heteroskedastic-robust standard errors are in parentheses. The symbols ${ }^{* * *},{ }^{* *}$, and ${ }^{*}$ indicate statistical significance at the 1,5 , and 10 percent levels, respectively.

\begin{tabular}{lcccccc}
\hline & \multicolumn{5}{c}{ Dependent Variable: Exit $=1 / 0$ at period t } \\
& $\mathrm{T}$ & $\mathrm{T}+1$ & $\mathrm{~T}+2$ & $\mathrm{~T}+3$ & $\mathrm{~T}-\mathrm{T}+3$ \\
& OLS & OLS & OLS & OLS & OLS & Probit \\
& $(1)$ & $(2)$ & $(3)$ & $(4)$ & $(5)$ & $(6)$ \\
\hline Target & $0.005^{* * *}$ & $0.022^{* * *}$ & $0.022^{* * *}$ & $0.014^{* * *}$ & $0.064^{* * *}$ & $0.069^{* * *}$ \\
& $(0.002)$ & $(0.002)$ & $(0.002)$ & $(0.002)$ & $(0.004)$ & $(0.005)$ \\
Log(employment) & $-0.013^{* * *}$ & $-0.013^{* * *}$ & $-0.010^{* * *}$ & $-0.008^{* * *}$ & $-0.046^{* * *}$ & $-0.046^{* * *}$ \\
& $(0.001)$ & $(0.001)$ & $(0.001)$ & $(0.001)$ & $(0.001)$ & $(0.001)$ \\
TFP & $-0.006^{* * *}$ & $-0.009^{* * *}$ & -0.004 & $-0.011^{* * *}$ & $-0.028^{* * *}$ & $-0.033^{* * *}$ \\
& $(0.002)$ & $(0.003)$ & $(0.003)$ & $(0.003)$ & $(0.006)$ & $(0.006)$ \\
Target*TFP & $-0.009^{*}$ & $-0.013^{* *}$ & $-0.016^{* * *}$ & 0.009 & $-0.03^{* * *}$ & $-0.021^{* *}$ \\
& $(0.005)$ & $(0.006)$ & $(0.006)$ & $(0.006)$ & $(0.011)$ & $(0.010)$ \\
Industry FE & Yes & Yes & Yes & Yes & Yes & Yes \\
Year FE & Yes & Yes & Yes & Yes & Yes & Yes \\
Observations & 49,679 & 49,679 & 49,679 & 49,679 & 49,679 & 49,679 \\
$\mathrm{R}^{2}$ & 0.02 & 0.02 & 0.02 & 0.30 & 0.19 & 0.22 \\
\hline
\end{tabular}


Table 2.6: The Effect of Takeovers on Efficiency with a Different Control Sample

The table reports estimates of a plant-level differences-in-differences regression of $Y_{i t}=\alpha+\beta_{1}$ After $_{t}+$ $\beta_{2}\left(\right.$ After $_{t} *$ Target $\left._{i}\right)+$ Plant \& Year FE $+\epsilon_{i t}$. The sample consists of mergers from the SDC M\&As database in which the announcement date is between 1981 and 2002, the completion date is within 360 days of the announcement, and the target firm is a publicly-listed firm that can be matched to the ASM/CMF, maintained at U.S. Census Bureau. Total factor productivity (TFP) is the residual from estimating a log linear Cobb-Douglas production function at the plant level, where one regresses the value of output on total payroll, capital stock, and material cost separately for each 3-digit SIC and year. Profit margin is the ratio of profit (sales minus material cost and labor cost) to sales. Return to capital is the ratio of profit to capital stock. The data are an unbalanced six-period panel $(\mathrm{T}-3, \mathrm{~T}-2, \mathrm{~T}-1, \mathrm{~T}+1, \mathrm{~T}+2$, and $\mathrm{T}+3)$ for target plants and control plants. $\mathrm{T}$, the year when the merger is completed, is dropped out from the analysis. After is a dummy variable that equals one for $\mathrm{T}+1, \mathrm{~T}+2$ and $\mathrm{T}+3$, and zero for $\mathrm{T}-1, \mathrm{~T}-2$ and $\mathrm{T}-3$. Target is a dummy variable that equals one if a plant's parent firm is acquired at year $\mathrm{T}$, and zero if a plant is a control plant. The control sample is constructed by selecting plants that are comparable to targeted plants in terms of industry, age, and employment prior to the takeover. Heteroskedastic-robust standard errors clustered at the firm level are in parentheses. The symbols ${ }^{* * *},{ }^{* *}$, and ${ }^{*}$ indicate statistical significance at the 1 , 5 , and 10 percent levels, respectively.

\begin{tabular}{lcccccc}
\hline & \multicolumn{2}{c}{ TFP } & \multicolumn{2}{c}{ Profit Margin } & \multicolumn{2}{c}{ Return to Capital } \\
& $(1)$ & $(2)$ & $(3)$ & $(4)$ & $(5)$ & $(6)$ \\
\hline After & $-0.006^{* *}$ & $-0.006^{* *}$ & -0.002 & -0.002 & $-0.056^{*}$ & $-0.054^{*}$ \\
& $(0.002)$ & $(0.003)$ & $(0.001)$ & $(0.001)$ & $(0.031)$ & $(0.031)$ \\
After*Target & $0.009^{*}$ & $0.009^{* *}$ & 0.001 & 0.001 & $0.169^{* * *}$ & $0.170^{* * *}$ \\
& $(0.005)$ & $(0.004)$ & $(0.003)$ & $(0.003)$ & $(0.048)$ & $(0.048)$ \\
Log(employment) & & $-0.021^{* * *}$ & & $-0.020^{* * *}$ & & $0.067^{*}$ \\
& & $(0.005)$ & & $(0.002)$ & & $(0.037)$ \\
Constant & $0.037^{* * *}$ & $0.146^{* * *}$ & $0.278^{* * *}$ & $0.380^{* * *}$ & $1.274^{* * *}$ & $0.923^{* * *}$ \\
& $(0.010)$ & $(0.028)$ & $(0.006)$ & $(0.012)$ & $(0.081)$ & $(0.210)$ \\
Plant FE & Yes & Yes & Yes & Yes & Yes & Yes \\
Year FE & Yes & Yes & Yes & Yes & Yes & Yes \\
Observations & 177,953 & 177,953 & 177,953 & 177,953 & 177,953 & 177,953 \\
$\mathrm{R}^{2}$ & 0.53 & 0.53 & 0.57 & 0.57 & 0.40 & 0.40 \\
\hline
\end{tabular}


Table 2.7: The Effect of Takeovers on Outputs and Inputs with a Different Control Sample

The table reports estimates of a plant-level differences-in-differences regression of $\log \left(Y_{i t}\right)=\alpha+$

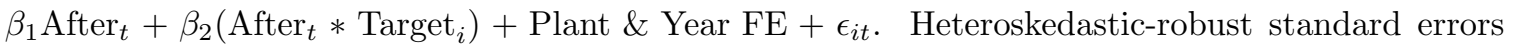
clustered at firm level are in parentheses. The symbols $* * *, * *$, and $*$ indicate statistical significance at the 1,5 , and 10 percent levels, respectively.

\begin{tabular}{|c|c|c|c|c|c|}
\hline & $\begin{array}{l}\text { Output } \\
\text { (1) }\end{array}$ & $\begin{array}{c}\text { Investment } \\
(2)\end{array}$ & $\begin{array}{l}\text { Materials } \\
\text { (3) }\end{array}$ & $\begin{array}{l}\text { Wage } \\
(4)\end{array}$ & $\begin{array}{c}\text { Employment } \\
(5)\end{array}$ \\
\hline After & $\begin{array}{c}-0.015^{* * *} \\
(0.003)\end{array}$ & $\begin{array}{c}-0.109^{* * *} \\
(0.013)\end{array}$ & $\begin{array}{c}-0.013^{* * *} \\
(0.005)\end{array}$ & $\begin{array}{c}0.001 \\
(0.002)\end{array}$ & $\begin{array}{c}-0.021^{* * *} \\
(0.004)\end{array}$ \\
\hline After*Target & $\begin{array}{c}-0.004 \\
(0.007)\end{array}$ & $\begin{array}{c}-0.110^{* * *} \\
(0.030)\end{array}$ & $\begin{array}{c}-0.010 \\
(0.009)\end{array}$ & $\begin{array}{c}-0.007^{* * *} \\
(0.003)\end{array}$ & $\begin{array}{c}-0.016^{* *} \\
(0.007)\end{array}$ \\
\hline Log(employment) & $\begin{array}{l}0.801^{* * *} \\
(0.008)\end{array}$ & $\begin{array}{l}1.095^{* * *} \\
(0.018)\end{array}$ & $\begin{array}{l}0.804^{* * *} \\
(0.009)\end{array}$ & $\begin{array}{c}-0.085^{* * *} \\
(0.004)\end{array}$ & \\
\hline Constant & $\begin{array}{l}5.357^{* * *} \\
(0.047)\end{array}$ & $\begin{array}{c}0.087 \\
(0.120)\end{array}$ & $\begin{array}{l}4.581^{* * *} \\
(0.050)\end{array}$ & $\begin{array}{l}11.012^{* * *} \\
(0.020)\end{array}$ & $\begin{array}{l}5.255^{\text {*** }} \\
(0.023)\end{array}$ \\
\hline Plant FE & Yes & Yes & Yes & Yes & Yes \\
\hline Year FE & Yes & Yes & Yes & Yes & Yes \\
\hline Observations & 177,953 & 177,953 & 177,953 & 177,953 & 177,953 \\
\hline $\mathrm{R}^{2}$ & 0.96 & 0.70 & 0.94 & 0.83 & 0.94 \\
\hline & & \multicolumn{2}{|c|}{ Production Worker } & \multicolumn{2}{|c|}{ Non-production Worker } \\
\hline & & $\begin{array}{l}\text { Wage } \\
(1)\end{array}$ & $\begin{array}{c}\text { Employment } \\
(2)\end{array}$ & $\begin{array}{c}\text { Wage } \\
(3)\end{array}$ & $\begin{array}{c}\text { Employment } \\
\text { (4) }\end{array}$ \\
\hline After & & $\begin{array}{l}0.006^{* * *} \\
(0.002)\end{array}$ & $\begin{array}{c}-0.025^{* * *} \\
(0.004)\end{array}$ & $\begin{array}{r}-0.021^{*} \\
(0.013)\end{array}$ & $\begin{array}{c}-0.007 \\
(0.006)\end{array}$ \\
\hline After*Target & & $\begin{array}{c}-0.004 \\
(0.004)\end{array}$ & $\begin{array}{c}-0.006 \\
(0.007)\end{array}$ & $\begin{array}{c}-0.017 \\
(0.027)\end{array}$ & $\begin{array}{c}-0.046^{* * *} \\
(0.012)\end{array}$ \\
\hline Log(employment) & & $\begin{array}{c}-0.073^{* * *} \\
(0.004)\end{array}$ & & $\begin{array}{l}0.377^{* * *} \\
(0.027)\end{array}$ & \\
\hline Constant & & $\begin{array}{l}10.808 \\
(0.023)\end{array}$ & $\begin{array}{c}4.966 \\
(0.023)\end{array}$ & $\begin{array}{c}8.634 \\
(0.152)\end{array}$ & $\begin{array}{c}3.639 \\
(0.030)\end{array}$ \\
\hline Plant FE & & Yes & Yes & Yes & Yes \\
\hline Year FE & & Yes & Yes & Yes & Yes \\
\hline Observations & & 177,953 & 177,953 & 177,953 & 177,953 \\
\hline $\mathrm{R}^{2}$ & & 0.78 & 0.93 & 0.55 & 0.88 \\
\hline
\end{tabular}




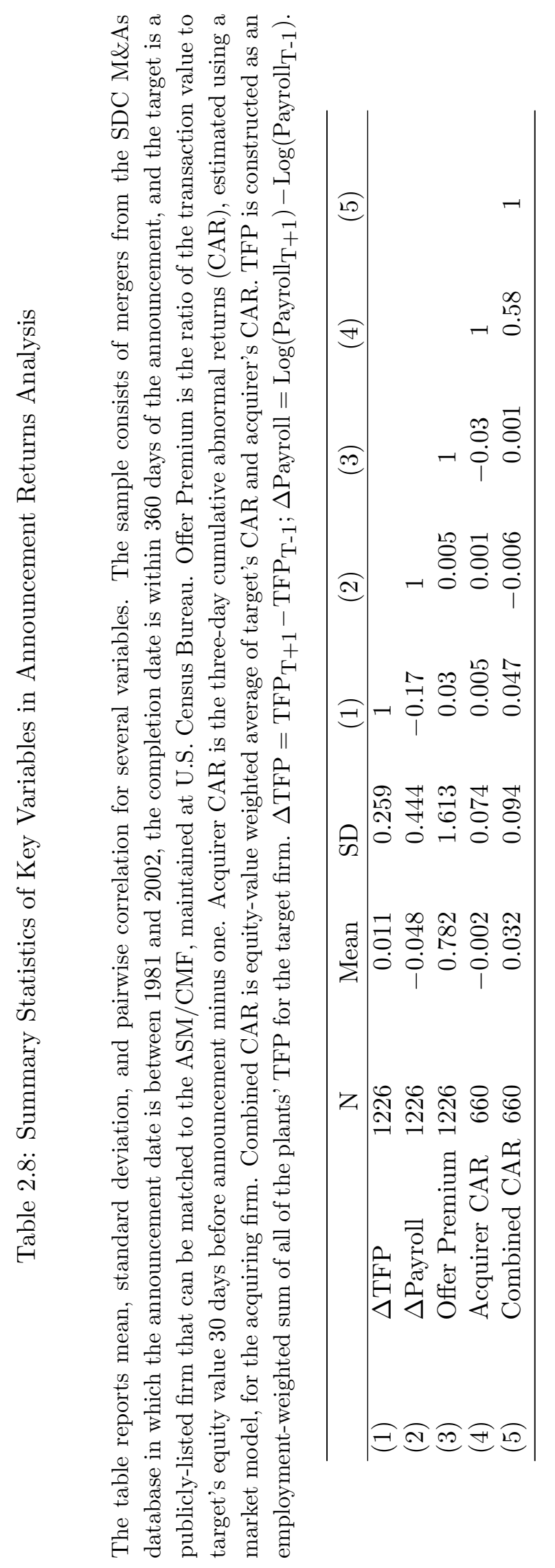


Table 2.9: Determinants of Combined CAR

The table reports estimates of a firm-level OLS regression explaining the combined CAR. Heteroskedastic-robust standard errors are in parentheses. The symbols ${ }^{* * *},{ }^{* *}$, and $*$ indicate statistical significance at the 1,5 , and 10 percent levels, respectively.

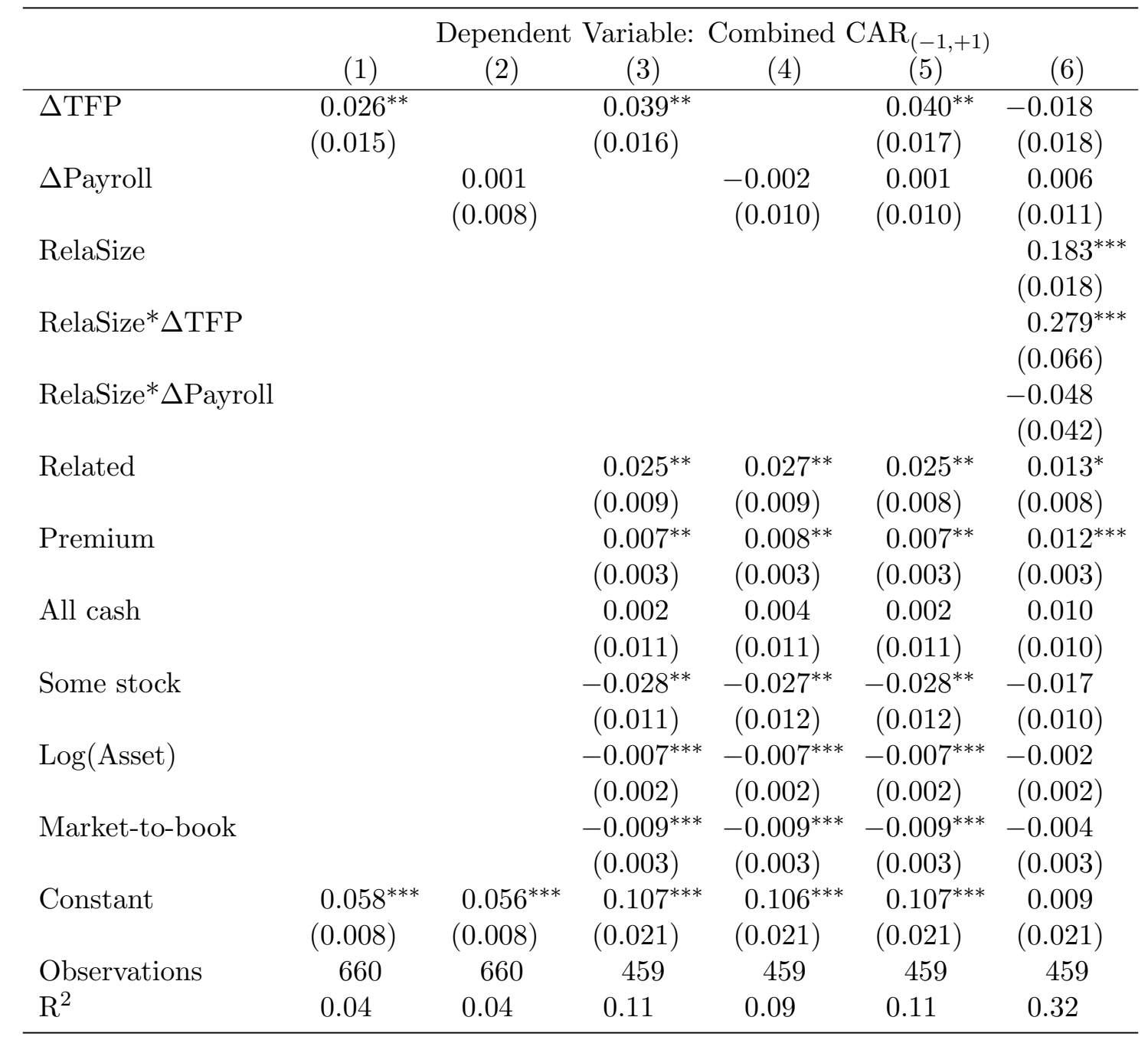


Table 2.10: Determinants of Offer Premium

The table reports estimates of firm-level OLS regression explaining the target's offer premium. The sample consists of mergers from the SDC M\&As database in which the announcement date is between 1981 and 2002, the completion date is within 360 days of the announcement, and the target is a publicly-listed firm that can be matched to the ASM/CMF, maintained at U.S. Census Bureau. Offer premium is the ratio of transaction value to target's market value 30 trading days before announcement. TFP is constructed as an employment-weighted sum of all of the plants' TFP for the target firm. $\Delta \mathrm{TFP}=\mathrm{TFP}_{\mathrm{T}+1}-\mathrm{TFP}_{\mathrm{T}-1} ; \Delta$ Payroll $=\mathrm{Log}\left(\right.$ Payroll $\left._{\mathrm{T}+1}\right)-\log \left(\right.$ Payroll $\left._{\mathrm{T}-1}\right)$. All Cash is a dummy variable that equals one if the entire transaction value was paid by cash and zero otherwise. Some Stock is a dummy variable that equals one if at least some portion of the transaction was paid by stock and zero otherwise. Private Acquirer is a dummy variable that equals one if the acquirer is not a publicly-listed firm and zero otherwise. Related is a dummy variable that equals one if target and acquirer share the same primary 2-digit SIC industry. 52-W High Price is the ratio of target's highest price in the previous 52 weeks to target's price 30 days before announcement. $\log$ (Assets) is the logarithm of the target's book assets. Market-to-book is the ratio of market value to the book value of assets for the target. All specifications control for target/acquirer industry (2-digit SIC) and year fixed effects. Heteroskedastic-robust standard errors are in parentheses. The symbols ${ }^{* *}, * *$, and $*$ indicate statistical significance at the 1,5 , and 10 percent levels, respectively.

\begin{tabular}{|c|c|c|c|c|c|c|}
\hline \multirow{3}{*}{$\Delta \mathrm{TFP}$} & \multicolumn{6}{|c|}{ Dependent Variable: Offer Premium } \\
\hline & $0.247^{* * *}$ & & $0.319^{* *}$ & & $0.379^{* *}$ & $0.455^{*}$ \\
\hline & $(0.109)$ & & $(0.122)$ & & $(0.122)$ & $(0.273)$ \\
\hline \multirow[t]{2}{*}{$\Delta$ Payroll } & & 0.039 & & 0.173 & 0.212 & 0.373 \\
\hline & & $(0.108)$ & & $(0.134)$ & $(0.136)$ & $(0.277)$ \\
\hline \multirow[t]{2}{*}{ RelaSize } & & & & & & $-1.565^{* * *}$ \\
\hline & & & & & & $(0.541)$ \\
\hline \multirow[t]{2}{*}{ RelaSize* $\Delta \mathrm{TFP}$} & & & & & & 0.071 \\
\hline & & & & & & $(0.618)$ \\
\hline \multirow[t]{2}{*}{ RelaSize* $\Delta$ Payroll } & & & & & & 0.048 \\
\hline & & & & & & $(0.443)$ \\
\hline \multirow[t]{2}{*}{ Related } & & & $0.287^{* *}$ & $0.305^{* *}$ & $0.303^{* *}$ & $0.355^{*}$ \\
\hline & & & $(0.142)$ & $(0.147)$ & $(0.147)$ & $(0.203)$ \\
\hline \multirow[t]{2}{*}{ All cash } & & & $-0.570^{* * *}$ & $-0.545^{* * *}$ & $-0.562^{* * *}$ & $-0.607^{* * *}$ \\
\hline & & & $(0.111)$ & $(0.110)$ & $(0.112)$ & $(0.178)$ \\
\hline \multirow[t]{2}{*}{ Some stock } & & & $-0.336^{* *}$ & $-0.314^{* *}$ & $-0.338^{* *}$ & $-0.485^{*}$ \\
\hline & & & $(0.184)$ & $(0.183)$ & $(0.184)$ & $(0.253)$ \\
\hline \multirow[t]{2}{*}{ 52-W High Price } & & & $0.520^{* *}$ & $0.528^{* * *}$ & $0.536^{* * *}$ & $0.745^{* * *}$ \\
\hline & & & $(0.157)$ & $(0.158)$ & $(0.159)$ & $(0.250)$ \\
\hline \multirow[t]{2}{*}{ Log(Asset) } & & & $0.071^{* *}$ & $0.074^{* *}$ & $0.076^{* *}$ & $0.187^{* *}$ \\
\hline & & & $(0.035)$ & $(0.037)$ & $(0.037)$ & $(0.084)$ \\
\hline \multirow[t]{2}{*}{ Market-to-book } & & & $-0.138^{* * *}$ & $-0.147^{* * *}$ & $-0.146^{* * *}$ & $-0.159^{* * *}$ \\
\hline & & & $(0.046)$ & $(0.045)$ & $(0.045)$ & $(0.059)$ \\
\hline \multirow[t]{2}{*}{ Constant } & $1.061^{* * *}$ & $1.049^{* * *}$ & $0.670^{* * *}$ & $0.670^{* * *}$ & $0.651^{* * *}$ & 0.445 \\
\hline & $(0.098)$ & $(0.098)$ & $(0.240)$ & $(0.240)$ & $(0.248)$ & $(0.401)$ \\
\hline Observations & 1226 & 1226 & 1004 & 1004 & 1004 & 561 \\
\hline $\mathrm{R}^{2}$ & 0.04 & 0.03 & 0.09 & 0.09 & 0.09 & 0.13 \\
\hline
\end{tabular}


Table 2.11: Determinants of Acquirer CAR

The table reports estimates of a firm-level OLS regression explaining the acquirer's CAR. Heteroskedastic-robust standard errors are in parentheses. All specifications control for target/acquirer industry (2-digit SIC) and year fixed effects. The symbols ***, **, and * indicate statistical significance at the 1,5 , and 10 percent levels, respectively.

\begin{tabular}{|c|c|c|c|c|c|c|}
\hline & (1) & $\begin{array}{c}\text { Depende } \\
(2)\end{array}$ & $\begin{array}{c}\text { t Variable: } \\
(3)\end{array}$ & $\begin{array}{c}\text { Acquirer } \\
(4)\end{array}$ & $\operatorname{AR}_{(-1,+1)}$ & $(6)$ \\
\hline$\Delta \mathrm{TFP}$ & $\begin{array}{c}0.010 \\
(0.012)\end{array}$ & & $\begin{array}{c}0.020 \\
(0.012)\end{array}$ & & $\begin{array}{c}0.019 \\
(0.012)\end{array}$ & $\begin{array}{c}0.001 \\
(0.016)\end{array}$ \\
\hline$\Delta$ Payroll & & $\begin{array}{c}0.001 \\
(0.007)\end{array}$ & & $\begin{array}{c}-0.004 \\
(0.007)\end{array}$ & $\begin{array}{c}-0.002 \\
(0.007)\end{array}$ & $\begin{array}{c}-0.005 \\
(0.009)\end{array}$ \\
\hline RelaSize & & & & & & $\begin{array}{c}-0.034^{* *} \\
(0.015)\end{array}$ \\
\hline RelaSize* $\Delta \mathrm{TFP}$ & & & & & & $\begin{array}{c}0.116^{* *} \\
(0.057)\end{array}$ \\
\hline RelaSize* $\Delta$ Payroll & & & & & & $\begin{array}{c}0.023 \\
(0.036)\end{array}$ \\
\hline Related & & & $\begin{array}{c}0.004 \\
(0.007)\end{array}$ & $\begin{array}{c}0.005 \\
(0.007)\end{array}$ & $\begin{array}{c}0.004 \\
(0.007)\end{array}$ & $\begin{array}{c}0.006 \\
(0.007)\end{array}$ \\
\hline Premium & & & $\begin{array}{c}0.004 \\
(0.003)\end{array}$ & $\begin{array}{c}0.004 \\
(0.003)\end{array}$ & $\begin{array}{c}0.004 \\
(0.003)\end{array}$ & $\begin{array}{c}0.003 \\
(0.003)\end{array}$ \\
\hline All cash & & & $\begin{array}{c}0.006 \\
(0.008)\end{array}$ & $\begin{array}{c}0.007 \\
(0.008)\end{array}$ & $\begin{array}{c}0.006 \\
(0.008)\end{array}$ & $\begin{array}{c}0.003 \\
(0.008)\end{array}$ \\
\hline Some stock & & & $\begin{array}{r}-0.015^{*} \\
(0.009)\end{array}$ & $\begin{array}{r}-0.015^{*} \\
(0.009)\end{array}$ & $\begin{array}{r}-0.015^{*} \\
(0.009)\end{array}$ & $\begin{array}{c}-0.017^{* *} \\
(0.009)\end{array}$ \\
\hline Log(Asset) & & & $\begin{array}{c}-0.005^{* *} \\
(0.002)\end{array}$ & $\begin{array}{c}-0.005^{* *} \\
(0.002)\end{array}$ & $\begin{array}{c}-0.005^{* *} \\
(0.002)\end{array}$ & $\begin{array}{c}-0.006^{* * *} \\
(0.002)\end{array}$ \\
\hline Market-to-book & & & $\begin{array}{c}-0.004^{* *} \\
(0.002)\end{array}$ & $\begin{array}{r}-0.004^{*} \\
(0.002)\end{array}$ & $\begin{array}{r}-0.004^{*} \\
(0.002)\end{array}$ & $\begin{array}{c}-0.005^{* *} \\
(0.002)\end{array}$ \\
\hline Constant & $\begin{array}{c}0.006 \\
(0.010)\end{array}$ & $\begin{array}{c}0.005 \\
(0.005)\end{array}$ & $\begin{array}{c}0.033^{* *} \\
(0.015)\end{array}$ & $\begin{array}{c}0.032^{* *} \\
(0.015)\end{array}$ & $\begin{array}{c}0.033^{* *} \\
(0.015)\end{array}$ & $\begin{array}{l}0.053^{* * *} \\
(0.018)\end{array}$ \\
\hline Observations & 660 & 660 & 459 & 459 & 459 & 459 \\
\hline $\mathrm{R}^{2}$ & 0.02 & 0.02 & 0.06 & 0.06 & 0.06 & 0.08 \\
\hline
\end{tabular}


Table 2.12: Wealth Redistribution between Employees and Shareholders in Dollars

The table reports estimates of a firm-level OLS regression explaining announcement returns in dollar amount. The sample consists of mergers from the SDC M\&As database in which the announcement date is between 1981 and 2002, the completion date is within 360 days of the announcement, and the target is a publicly-listed firm that can be matched to the ASM/CMF, maintained at U.S. Census Bureau. Dollar Combined $\mathrm{CAR}_{(-1,+1)}$ is the sum of target's Dollar $\mathrm{CAR}_{(-1,+1)}$ (calculated as the product of target's $\mathrm{CAR}_{(-1,+1)}$ and target's market value) and acquirer's Dollar $\mathrm{CAR}_{(-1,+1)}$ (calculated as the product of acquirer's $\mathrm{CAR}_{(-1,+1)}$ and acquirer's market value). $\Delta$ Dollar Payroll $=$ Dollar Payroll ${ }_{\mathrm{T}+1}-$ Dollar Payroll $_{\mathrm{T}-1}$ where the total payroll is expressed in 2005 dollars. All Cash is a dummy variable that equals one if the entire transaction was paid by cash and zero otherwise. Some Stock is a dummy variable that equals one if at least some portion of the transaction was paid by stock and zero otherwise. Private Acquirer is a dummy variable that equals one if the acquirer is not a publicly-listed firm and zero otherwise. Premium is the ratio of transaction value to target's market value 30 trading days before announcement. Related is a dummy variable that equals one if target and acquirer share the same primary 2-digit SIC industry. Log(Assets) is the logarithm of the target's book assets. Market-to-book is the ratio of market value to the book value of assets for the target. $\log$ (AssetsAcquirer) is the logarithm of acquirer's book assets. Market-to-bookAcquirer is the ratio of market value to the book value of assets for the acquirer. All specifications control for target/acquirer industry (2-digit SIC) and year fixed effects. Heteroskedastic-robust standard errors are in parentheses. The symbols ${ }^{* * *},{ }^{* *}$, and ${ }^{*}$ indicate statistical significance at the 1,5 , and 10 percent levels, respectively.

\begin{tabular}{|c|c|c|c|c|c|c|}
\hline & \multicolumn{3}{|c|}{ Dollar Premium } & \multicolumn{3}{|c|}{ Dollar Combined CAR } \\
\hline & $(1)$ & $(2)$ & $(3)$ & $(4)$ & $(5)$ & $(6)$ \\
\hline$\Delta$ Dollar Payroll & $\begin{array}{c}-5.46^{* * *} \\
(1.14)\end{array}$ & $\begin{array}{c}-1.972^{*} \\
(1.20)\end{array}$ & $\begin{array}{c}-5.80^{* * *} \\
(1.73)\end{array}$ & $\begin{array}{c}-1.16 \\
(1.00)\end{array}$ & $\begin{array}{c}-1.62 \\
(1.23)\end{array}$ & $\begin{array}{c}-0.75 \\
(1.13)\end{array}$ \\
\hline Related & $\begin{array}{l}215.66^{* * *} \\
(68.06)\end{array}$ & $\begin{array}{l}159.97^{* * *} \\
(57.28)\end{array}$ & $\begin{array}{l}123.41 \\
(81.75)\end{array}$ & $\begin{array}{c}84.51 \\
(74.91)\end{array}$ & $\begin{array}{c}69.06 \\
(72.44)\end{array}$ & $\begin{array}{c}71.58 \\
(76.29)\end{array}$ \\
\hline All Cash & $\begin{array}{c}-115.52^{* *} \\
(47.72)\end{array}$ & $\begin{array}{l}-9.98 \\
(40.77)\end{array}$ & $\begin{array}{c}-242.80^{* *} \\
(78.83)\end{array}$ & $\begin{array}{c}-190.67^{* *} \\
(79.64)\end{array}$ & $\begin{array}{r}-66.56 \\
(77.53)\end{array}$ & $\begin{array}{c}-194.66^{* *} \\
(95.09)\end{array}$ \\
\hline Some Stock & $\begin{array}{l}408.57^{* * *} \\
(85.38)\end{array}$ & $\begin{array}{c}192.03^{*} \\
(69.31)\end{array}$ & $\begin{array}{c}156.13 \\
(106.86)\end{array}$ & $\begin{array}{c}-184.47^{* *} \\
(86.11)\end{array}$ & $\begin{array}{c}-205.68^{* *} \\
(85.55)\end{array}$ & $\begin{array}{r}-170.25^{*} \\
(100.54)\end{array}$ \\
\hline $\log ($ Asset $)$ & & $\begin{array}{l}293.88^{* * *} \\
(29.14)\end{array}$ & & & $\begin{array}{l}155.42^{* *} \\
(39.89)\end{array}$ & \\
\hline Market-to-book & & $\begin{array}{l}141.29^{\text {*** }} \\
(46.86)\end{array}$ & & & $\begin{array}{c}-18.86 \\
(52.83)\end{array}$ & \\
\hline Log(AssetAcquirer) & & & $\begin{array}{l}178.96^{\text {*** }} \\
(23.72)\end{array}$ & & & $\begin{array}{l}67.28^{* *} \\
(30.19)\end{array}$ \\
\hline Market-to-bookAcquirer & & & $\begin{array}{l}91.94^{* * *} \\
(36.67)\end{array}$ & & & $\begin{array}{c}-107.21^{* * *} \\
\quad(39.23)\end{array}$ \\
\hline Constant & $\begin{array}{l}181.16^{* * *} \\
(36.97)\end{array}$ & $\begin{array}{c}1577.9^{* * *} \\
(169.24)\end{array}$ & $\begin{array}{c}-1143.91^{* * *} \\
(178.33)\end{array}$ & $\begin{array}{l}313.94 \\
(71.41)\end{array}$ & $\begin{array}{c}-538.94^{* *} \\
(233.76)\end{array}$ & $\begin{array}{l}-34.61 \\
(218.44)\end{array}$ \\
\hline Observations & 1226 & 1004 & 513 & 660 & 562 & 459 \\
\hline $\mathrm{R}^{2}$ & 0.14 & 0.40 & 0.29 & 0.02 & 0.10 & 0.07 \\
\hline
\end{tabular}


Table 2.13: Redistribution between Employees and Shareholders from Fringe Benefits

The table reports estimates of a firm-level OLS regression explaining announcement returns. The sample consists of mergers from the SDC M\&As database in which the announcement date is between 1981 and 2002, the completion date is within 360 days of the announcement, and the target is a publicly-listed firm that can be matched to the ASM/CMF, maintained at U.S. Census Bureau. $\mathrm{CAR}_{(-1,+1)}$ is the three-day cumulative abnormal return estimated using a market model adjusted for CRSP value-weighted market index. TFP is constructed as an employment-weighted sum of all of the plants' TFP for the target firm. $\Delta \mathrm{X}=\log \left(\mathrm{X}_{\mathrm{T}+1}\right)-\log \left(\mathrm{X}_{\mathrm{T}-1}\right)$ where $\mathrm{X}$ includes Fringe Benefits, Total Employment, and Wage rate. All Cash is a dummy variable that equals one if the entire transaction was paid by cash and zero otherwise. Some Stock is a dummy variable that equals one if at least some portion of the transaction was paid by stock and zero otherwise. Private Acquirer is a dummy variable that equals one if the acquirer is not a publicly-listed firm and zero otherwise. Premium is the ratio of transaction value to target's market value of 30 trading days before announcement. Related is a dummy variable that equals one if target and acquirer share the same primary 2-digit SIC industry. 52-W High Price is the ratio of target's highest price in the previous 52 weeks to target's price 30 days before announcement. $\log$ (Assets) is the logarithm of the acquirer's book assets. Market-to-book is the ratio of market value to the book value of assets for the acquirer. All specifications control for target/acquirer industry (2-digit SIC) and year fixed effects. Heteroskedastic-robust standard errors are in parentheses. The symbols ${ }^{* * *},{ }^{* *}$, and * indicate statistical significance at the 1,5 , and 10 percent levels, respectively.

\begin{tabular}{|c|c|c|c|c|c|c|}
\hline & \multicolumn{2}{|c|}{ Premium } & \multicolumn{2}{|c|}{ Acquirer CAR } & \multicolumn{2}{|c|}{ Combined CAR } \\
\hline & (1) & $(2)$ & $(3)$ & $(4)$ & $(5)$ & $(6)$ \\
\hline$\Delta$ Fringe Benefits & $\begin{array}{c}0.126 \\
(0.102)\end{array}$ & & $\begin{array}{c}0.003 \\
(0.006)\end{array}$ & & $\begin{array}{c}-0.003 \\
(0.008)\end{array}$ & \\
\hline$\Delta$ Employment & & $\begin{array}{c}0.241^{*} \\
(0.126)\end{array}$ & & $\begin{array}{c}-0.002 \\
(0.007)\end{array}$ & & $\begin{array}{c}-0.002 \\
(0.010)\end{array}$ \\
\hline$\Delta$ Wage Rate & & $\begin{array}{c}0.064 \\
(0.245)\end{array}$ & & $\begin{array}{c}-0.008 \\
(0.015)\end{array}$ & & $\begin{array}{c}0.015 \\
(0.021)\end{array}$ \\
\hline Related & $\begin{array}{c}0.295^{* *} \\
(0.121)\end{array}$ & $\begin{array}{c}0.306^{* *} \\
(0.121)\end{array}$ & $\begin{array}{c}0.006 \\
(0.007)\end{array}$ & $\begin{array}{c}0.006 \\
(0.007)\end{array}$ & $\begin{array}{l}0.027^{* * *} \\
(0.009)\end{array}$ & $\begin{array}{l}0.027^{* * *} \\
(0.009)\end{array}$ \\
\hline All cash & $\begin{array}{c}-0.570^{* * *} \\
(0.130)\end{array}$ & $\begin{array}{c}-0.557^{* * *} \\
(0.130)\end{array}$ & $\begin{array}{c}0.004 \\
(0.008)\end{array}$ & $\begin{array}{c}0.004 \\
(0.008)\end{array}$ & $\begin{array}{c}-0.002 \\
(0.011)\end{array}$ & $\begin{array}{c}-0.002 \\
(0.011)\end{array}$ \\
\hline Some stock & $\begin{array}{c}-0.337^{* *} \\
(0.153)\end{array}$ & $\begin{array}{c}-0.336^{* *} \\
(0.153)\end{array}$ & $\begin{array}{r}-0.016^{*} \\
(0.008)\end{array}$ & $\begin{array}{r}-0.016^{*} \\
(0.009)\end{array}$ & $\begin{array}{c}-0.03^{* * *} \\
(0.011)\end{array}$ & $\begin{array}{c}-0.03^{* * *} \\
(0.011)\end{array}$ \\
\hline Log(Asset) & $\begin{array}{c}0.074^{* *} \\
(0.033)\end{array}$ & $\begin{array}{c}0.078^{* *} \\
(0.032)\end{array}$ & $\begin{array}{c}-0.005^{* *} \\
(0.002)\end{array}$ & $\begin{array}{c}-0.005^{* *} \\
(0.002)\end{array}$ & $\begin{array}{c}-0.007^{* * *} \\
(0.002)\end{array}$ & $\begin{array}{c}-0.007^{* * *} \\
(0.002)\end{array}$ \\
\hline Market-to-book & $\begin{array}{c}-0.145^{* *} \\
(0.054)\end{array}$ & $\begin{array}{c}-0.153^{* * *} \\
(0.054)\end{array}$ & $\begin{array}{r}-0.004^{*} \\
(0.002)\end{array}$ & $\begin{array}{r}-0.004^{*} \\
(0.002)\end{array}$ & $\begin{array}{c}-0.008^{* * *} \\
(0.003)\end{array}$ & $\begin{array}{c}-0.008^{* * *} \\
(0.003)\end{array}$ \\
\hline 52-W High Price & $\begin{array}{l}0.531^{* * *} \\
(0.075)\end{array}$ & $\begin{array}{l}0.538^{* * *} \\
(0.075)\end{array}$ & $\begin{array}{r}-0.009^{*} \\
(0.005)\end{array}$ & $\begin{array}{r}-0.009^{*} \\
(0.005)\end{array}$ & $\begin{array}{c}-0.009 \\
(0.007)\end{array}$ & $\begin{array}{c}-0.009 \\
(0.007)\end{array}$ \\
\hline Constant & $\begin{array}{l}0.645^{\text {*** }} \\
(0.232)\end{array}$ & $\begin{array}{l}0.658^{* * *} \\
(0.231)\end{array}$ & $\begin{array}{l}0.042^{* * *} \\
(0.015)\end{array}$ & $\begin{array}{l}0.043^{* * *} \\
(0.015)\end{array}$ & $\begin{array}{l}0.119^{* * *} \\
(0.021)\end{array}$ & $\begin{array}{l}0.118^{* * *} \\
(0.021)\end{array}$ \\
\hline Observations & 1004 & 1004 & 459 & 459 & 459 & 459 \\
\hline $\mathrm{R}^{2}$ & 0.09 & 0.09 & 0.06 & 0.06 & 0.10 & 0.10 \\
\hline
\end{tabular}




\section{CHAPTER III}

\section{Unions, Workers, and Takeovers}

\subsection{Introduction}

Economists have long recognized that labor unions introduce an important friction that can impose costs on firms' operations. ${ }^{1}$ In an influential critique of the literature, Freeman and Medoff (1984) remarked, "Everyone 'knows' that unions raise wages. The questions are how much, under what conditions, and with what effects on the overall performance of the economy." Indeed, recent papers by DiNardo and Lee (2004) and Lee and Mas (2009) find that the average effects of labor unions on productivity and market value are perhaps overstated. In this paper, I depart from the previous literature by analyzing the effect of labor unions in the context of takeovers. This context is particularly interesting because takeovers present a shock that could negatively affect target firm's workers and undermine the strength of labor unions. Therefore, workers and their unions have a vital interest in protecting their interests during takeovers. For instance, during the merger negotiation between Delta Airlines and Northwest Airlines, Stephen Gordon, Chair of the International Association of Machinists (IAM) ${ }^{2}$ unit that covers Northwest Airlines, stated, ${ }^{3}$

If the merger does go through, it inevitably is going to result in massive job

\footnotetext{
${ }^{1}$ Research to date has examined the effect of labor unions on wages and employment (Dinardo and Lee (2004) and references therein), leverage and financing choice (Bronars and Deere, 1991; Matsa, 2010), cash holdings (Klasa, Maxwell, and Ortiz-Molina, 2009), and cost of equity (Chen, Kacperczyk, and Ortiz-Molina, 2009), among others.

${ }^{2}$ The IAM is the airline's largest union, representing about 12,500 baggage handlers, reservation agents and other ground workers.

${ }^{3}$ Except from Ho, David, (2008, September 26). "Northwest Investors Approve Delta Merger Amid Union Unrest". Cox News Service. Available from http://www.ajc.com/ajccars/content/shared/money/stories/2008/09/NORTHWEST26_COX_F6493.html
} 
loss, dislocation, consolidation and closures, which will have a devastating affect on airline employees, their families. No one is going to trade their future for a couple of extra dollars... Delta, with its roots in the deep south, maintains a plantation style of management... We will fight until we are recognized.

In this paper, I consider the effect of labor unions from two perspectives. First, I examine whether union strength affects merger gains to shareholders during the announcement period, and the division of such gains between target and acquirer. Second, I focus on whether target firm's union power mitigates the impact of a takeover on the target's employees' wages and job security.

The first part of the analysis uses information for target firm's union power and targetacquirer union power difference to explain the cross-sectional variations in gains to shareholders. Target firm's union power can affect merger gains in several ways. Heavilyunionized firms tend to have sticky wages and rigid employment contracts. This may make such firms unattractive targets. One may argue that acquiring a heavily-unionized firm may create low synergy benefits. Alternatively, because the target firm's union is at a disadvantaged position after the takeover, one can also argue that the acquirers can unlock greater efficiency gains by reducing the target's union power and constraints on the firm's operation. Thus, the effect of union power on merger gains becomes an empirical question. In addition, the difference in union strength between the target and the acquirer can play an important role. The realization of synergy gains hinges on post-merger integration, during which target and acquirer's respective unions may have to cooperate. It might be more difficult for two firms with distinct union influences to integrate and bring forward synergy benefits.

I analyze the relation between union power and shareholder gains empirically using a sample of 1,940 completed mergers between publicly-listed firms between 1984 and 2009 . I examine the effects of target's union power and target-acquirer union power difference on gains to shareholders of the merging firms (the offer premium to target, and the 3day announcement abnormal returns to the acquirer and to the combined firm). I use firms' industry labor force unionization rate (the fraction of workers in a industry that 
are covered by union contract) to proxy for union power. ${ }^{4}$ The results show that target firm's pre-merger union power is positively associated with gains to shareholders for the combined firm as well for the target and the acquirer separately. Other things equal, a change from the 25 th to the 75 th percentile of target's union membership leads to about 1 percentage points higher 3-day announcement returns to the combined firm. This amount is considerable, compared with the median value of the combined announcement returns of 1.3\%. Furthermore, such a change is associated with a 25 percentage points higher offer premium to target and a 1 percentage points higher announcement returns to the acquirer. I also find that the larger the target's union power relative to the acquirer's, the lower the offer premium to the target.

I investigate also the impact of the union power on the division of merger gains. Following Ahern (2010), I define a target's abnormal gain relative to the acquirer's as the difference in dollar abnormal returns between the target and the acquirer, scaled by the sum of the merging firms' equity value. I find that a target's gains relative to the acquirer is negatively associated with the target's union power but positively associated with the difference in union power between targets and acquirers.

The above results suggest that stock market perceives target's high union power as beneficial to the merger. This is consistent with the argument that takeovers are expected to reduce the target firm's union power and to help unlock the value previously captured by the union. Yet stock prices reacts negatively when the difference between target's and acquirer's union strength is large. This finding supports the hypothesis that relatively comparable union strength between target and acquirer can ease post-merger firm integration and thereby facilitate the realization of the synergy benefits.

To shed light on the underlying mechanisms that affect the relation between announcement returns and union power, I provide empirical evidence on the effect of target's union strength on employee's wages and employment subsequent to mergers. Previous studies demonstrate that labor union help boost wages for union members. This result, however, might not hold in the context of mergers. Shleifer and Summers (1988) first propose a

\footnotetext{
${ }^{4}$ Firm level union information is very difficult to obtain, therefore existing studies mostly use industry level unionization information as proxies.
} 
view of takeovers as breaching implicit labor contracts between incumbent managers and workers. Pagano and Volpin (2005) advance that often times incumbent management form alliances with employees by offering them higher wages to fend against takeover threat. These two arguments imply that target's union strength can potentially exert a negative effect on the employees' wages and job security.

To empirically investigate how labor union strength affects target's wage and employment during a merger, I analyze a data set that consists of a large sample of firms involved in takeovers. I use establishment-level data from the Longitudinal Business Database (LBD), maintained at the U.S. Census Bureau. The LBD covers the entire non-farm private sector and includes annual data on employment and payroll for about 5 million firms and 6 million establishments - i.e., specific factories, offices, retail outlets, and other distinct physical locations where business takes place.

I link the LBD with information from Securities Data Company's (SDC) M\&As database. I perform the analysis on a sample of 4,149 publicly-listed target firms that were acquired between 1981 and 2002. These target firms owned more than 240,000 establishments immediately before the merger. I follow wage and employment dynamics at the establishment level of the target firms, prior to and subsequent to a takeover. I find that three years following the takeover, wage and wage growth rate are lowered by 2 to 3 percentage points, while employment and employment growth rate are lowered by about 2 percentage points, relative to a sample of control establishments that are comparable in terms of industry, age, and size. In sum, workers in the target firm are adversely affected following a takeover.

I then analyze how the target's labor union can potentially mitigate these effects. A fundamental obstacle to estimating the effect of unionization on labor outcomes is selection bias: wage/employment within unionized plants may differ for (possibly unobservable) reasons other than the fact that workers there are represented by a union. To identify the impact of unionization, I compare the effects of union in different bargaining environments. I differentiate states with "Right-to-work" (RTW) laws" and states without such laws where the bargaining environment is less favorable to unions. I explore whether union's effect on

\footnotetext{
${ }^{5}$ Essentially, a state with a RTW law prohibits agreements between labor unions and employers making membership or payment of union dues or fees a condition of employment, either before or after hiring.
} 
post-takeover labor outcome is more pronounced when the establishment is located in a state without RTW laws. This identification strategy relies on a triple interaction term with three variables: (1) Before versus after takeover, (2) RTW states versus non-RTW states, and (3) union membership. This interaction term intends to compare the effect of union power on labor between establishments in the RTW states versus in non-RTW states after merger. My results show that the post-merger negative effects of union on wages, wage growth and employment are more pronounced for those establishments located in states with RTW laws. Thus, the effects of labor unions on wages and employment are particularly weak in places where the union faces a less favorable bargaining environment and especially after the takeover when the labor union is disadvantaged. If one assumes that these labor restructuring activities create synergy benefits, takeovers can bring gains to shareholders by easing the constraints previously imposed upon by labor unions.

The current study makes several contributions to the literature on mergers and acquisitions. It adds to a limited number of studies that attempt to explain the shareholder wealth gains from the perspective of employee wealth redistributions (see, e.g., Rosett, 1990; Pontiff, Shleifer, and Weisbach, 1990; Becker, 1995). My study differs from these in several important aspects. First, these studies focus on gains to target firm's shareholder, while I consider the impact of labor union on shareholders wealth changes not only for the target firm, but also for the acquiring firm and combined firm. These two aspects are important metrics to evaluate a merger. Gains to target and acquirer combined determines whether a merger creates value and gains to acquirers can inform whether a merger benefits its ultimate owner. Second, I take into account the effect of the difference between target's and acquirer's union strength, whereas previous studies focus exclusively on labor union in one firm. My results highlight the interaction effect between target and acquirer labor unions. Last, prior studies focus on hostile takeovers and leverage buyouts in the 1980s. Considering that most recent mergers are friendly negotiated mergers, the current study provides evidence of this form of merger. My study is also related to a voluminous literature on the effect of labor unions (see, e.g., Freeman and Medoff, 1984; DiNardo and Lee, 2004). I extend this literature by providing some of the first empirical evidence on the role of labor unions in the unique context of mergers and acquisitions. 
The paper proceeds as follows. Section 3.2 briefly reviews prior literature. I analyze the relation between union power and merging firms' announcement returns in Section 3.3. Section 3.4 investigates the impact of union power on target firm's wage and employment outcomes following a takeover. Section 3.5 concludes and discusses future work.

\subsection{Literature review}

Economists have long been interested in the effect of union on wages, employment, and performance. Conventional estimates suggest that there still exists a sizable union wage premium: demographically similar union workers are paid 15 percent or more than their nonunion counterparts. To the extent that employers are sensitive to the price of labor, this may lead to large reductions in employment. This textbook result, however, is much under debate. LaLonde, Marschke, and Troske (1996) combine information on union organizing activity from the U.S. National Labor Relations (NLRB) Board Representation Case files with information on a wide range of economic variables form the LRD and find successful organization is associated with significant declines in subsequent employment and output, but not so much in wages. Using the same data sets in a regression discontinuity framework, DiNardo and Lee (2004) conclude that the impacts of union on wage and employment are extremely small.

Existing studies also consider the effect of unions on firms' financial decisions. Bronars and Deere (1991) document a positive correlation between leverage and the degree of unionization. Chen, Kacperczyk, and Ortiz-Molina (2009) find that labor union imposes restrictions on firms' operational flexibility. Klasa, Maxwell, and Ortiz-Molina (2009) document that labor union power induces firms to hold less cash. Matsa (2010) posits that firms strategically use debt financing to improve a firm's bargaining position with union. However, none of these studies examine whether labor unions relate to firm valuation. I make the first attempt to investigate how labor unions impact firms' value in the context of takeovers.

This paper is also related to the literature on merger and labor. Rosett (1990) and Becker (1995) both reach the conclusion that only a small portion of the gains from a 
takeover can be attributed to a reduction in wages. Brown and Medoff (1988) is the first paper devoted to analyzing the impact of acquisitions on labor. They examine a sample of mostly small firms in the state of Michigan and found that, depending on the type of takeover, wage effects range from $5 \%$ reductions to $5 \%$ increases, and employment effects from $5 \%$ reductions to $9 \%$ increases. Most of the firms in their sample are small. Kaplan (1989) focuses on 76 public-to-private leveraged buyouts (LBOs) during the 1980s. He finds that the median firm lost $12 \%$ of its employment on an industry-adjusted basis from the end of the fiscal year prior to the private equity transaction to the end of the fiscal year after the transaction. Bhagat, Shleifer, and Vishny (1990) examine layoffs for a sample of 62 hostile takeover attempts, finding that layoffs are an important but not a dominant source of hostile takeover gains, accounting perhaps for $11 \%$ to $26 \%$ of the premium on average. Layoffs are disproportionately targeted at white-collar employees in the course of consolidation of headquarters. Lichtenberg (1992) uses a sample of large manufacturing plants from the Census Bureau's Longitudinal Research Database (LRD), finds that ownership change associated with reductions in both employment and wages at central offices, but not at establishments engaged in production. McGuckin and Nguyen (2001) use plant-level data for the entire manufacturing sector for the period between 1977 and 1987 to examine the effects of ownership changes on employment, wages and plant closing and find that ownership changes are associated with positive outcomes in terms of jobs, wages and the survival probability. A recent study by Ouimet and Zarutskie (2009) documents that employee wages increase in a two-year period around a merger.

The recent work by Davis et al. (2009) is closest in spirit to this paper. They use Census Bureau's LBD to follow employment at all private equity-backed companies in before and after private equity transactions and show that targeted establishments exhibit net employment contraction, higher job destruction, and establishment exit relative to controls. My study differs from theirs in three dimensions. First, I focus on merger and acquisitions rather than private equity transactions, which only constitute a small portion of total takeover transactions. Second, I consider the effect of takeovers on wages in addition to employment. Third, I incorporate labor unions into my analysis. 


\subsection{Effect of union strength on shareholder gains}

The first objective of the study is to analyze the relation between merging firms' union strength and announcement returns. To pursue this, I construct a sample of mergers with available information on stock prices around announcement and on firm's union strength.

\subsubsection{Identifying mergers and acquisitions}

The data on mergers and acquisitions is from the SDC's U.S. Mergers and Acquisitions database. Only deals completed between January 1st, 1984 and December 31st, 2009 and completed within 1000 days of the announcement are included. The transaction value of the deal is restricted to be at least $\$ 1$ million. Both the targets and the acquirers must be publicly-traded with stock prices available from the Center for Research in Security Prices (CRSP). Acquirers must own less than $50 \%$ of the target's shares before and $100 \%$ after the merger.

\subsubsection{Union membership}

A typical problem in studies on labor unions is the lack of large-sample firm-level unionization data ${ }^{6}$ Following previous studies, I measure union power as the percentage of employed workers covered by unions in the collective bargaining with the employers in a firm's primary industry. ${ }^{7}$

I obtain industry level unionization data for the period 1983 to 2009 from the Union Membership and Coverage Database at www.unionstats.com, maintained by Barry Hirsch and David Macpherson. The data are compiled from the Current Population Survey based on the method of the Bureau of Labor Statistics. ${ }^{8}$

I document the source and amount of variation in union membership in Figure 1. In the time series figure, there is a decreasing trend in unionization rates over time nationally,

\footnotetext{
${ }^{6}$ Prior studies using firm-level unionization information usually have a small sample size. LaLonde, Marschke, and Troske (1996), DiNardo and Lee (2004) both use a matched data base between NLRB and LRD. They identify union power from union representation election outcome.

${ }^{7}$ Current Population Survey uses Census Industry Classification (CIC) to classify industries. A CIC corresponds roughly to a 3-digit SIC industry.

${ }^{8}$ For a detailed description on the construction of this database, please refer to Hirsch and Macpherson (2003).
} 
with the aggregate union coverage decreasing from $17 \%$ in 1983 to $7 \%$ in 2008 . In the industry figure, I show the mean value of unionization rates for the ten most and the ten least unionized industries in the manufacturing sector in addition to that of air transportation industry. Paper, metals, and transportation equipment are among the most unionized industries, with average rates above $40 \%$ during the period 1983-2009. In contrast, apparel and instrument industries have an average unionization rate of about $6 \%$. Chen, Kacperczyk, and Ortiz-Molina (2009) shows that the primary source of variation in union density in the cross-sectional differences is the industry unionization rates. In my sample, a typical firm operates in an industry in which about $10 \%$ of the workers are unionized. This number ranges from 0 to as high as $65 \%$ for some industry/year.

\subsubsection{Variables and specifications}

I combine information on firm's announcement returns and data on union membership. The resulting sample contains 1939 merger transactions completed between 1984 and 2009 . To estimate the effect of union strength on announcement returns, I augment the standard regressions of announcement returns with the target firm's union power and the targetacquirer union power difference. The specification is as follows:

$$
\left.Y=\alpha+\beta_{1} \text { (Target's Union }\right)+\beta_{2}(\text { Target-Acquirer Union })+X \gamma+\epsilon
$$

In Equation (3.1), the dependent variable $Y$ includes target's offer premium, acquirer' 3-day cumulative abnormal returns (CAR), the 3-day CAR for the target and the acquiring firm combined. I measure offer premiums as the ratio of the transaction value to target's market value 30 days before announcement. CAR is estimated using a market model estimated over the $(-205,-6)$ interval. The combined announcement returns measure the total surplus to shareholders generated by the merger. Later, I also consider the target's gains relative to the acquirer's as a dependent variable using the same specification. Target's abnormal gains relative to acquirer's is calculated as the difference of dollar abnormal returns between the target and the acquirer, scaled by the sum of the merging firms' equity value. Target's Union is the fraction of labor force that is covered by union contract of 
the industry in which the target firm operates (recorded in CRSP). Target-Acquirer Union is calculated by subtracting acquirer's union density from target's union density. On average, Target's Union is about $9.6 \%$ and Target-Acquirer Union is about $1.1 \%$, which is statistically different from zero at $1 \%$ significance level.

The vector $X$ mainly includes two groups of control variables: Target/acquirer firm size and deal characteristics. Deal characteristics include method of payment, merger types, and target-acquirer industry relatedness. Following the existing literature, I create two variables All Cash and Some Stock to distinguish between transactions entirely financed by cash and stock, respectively. I include an indicator variable that equals one if the merger is a tender

offer. I measure target-acquirer relatedness using a dummy variable that equals one if the target and the acquirer share the same primary two-digit SIC industry.

\subsubsection{Results}

Table 3.1 presents results from estimating Equation (3.1) for determinants of offer premium and acquirer' CAR. The coefficients on Target Union are positive across different specifications for both dependent variables. Column (1) and (4) report univariate regression results. The results are very similar after controlling for industry and year fixed effects. This result indicates that target's union strength has a positive effect on both target and acquirer's shareholder wealth gains. The point estimate of 2.232 in the first column implies that a 10 percentage points increase in target's union membership (equivalent to moving from the 25 th to the 75 th percentile of Target Union) is associated with 22 percentage points increase in target's offer premium. This effect is considerable given that the median of Offer Premium is 52\%. As for gains to the acquiring firm's shareholders, a 10 percentage points increase in target's union membership leads to almost 1 percentage points increase in acquirer' 3-day abnormal returns. This is a substantial amount, compared with the median value of -0.01 . I then turn attention to the results on the difference between union power between target and acquirer. The results show that Target-Acquirer Union has a negative effect on offer premium and the point estimate is statistically significant at $5 \%$ level. The point estimate of -1.562 indicates that a target with union membership 10 percentage points higher than the acquirer receives a premium that is 16 percentage points lower compared 
with a target with union membership about the same as the acquirer. Target-Acquirer Union is also negatively associated with Acquirer CAR, although the point estimate is not statistically different from zero at a conventional confidence level.

I next examine the effect of union power on the total synergy gains and the target's share of gains relative to acquirer's. The results in Table 3.2 reveal that mergers produce more synergy gains when the target firm operates in a more heavily unionized industry. Holding other things constant, compared The point estimate of 0.115 in the first column implies that a 10 percentage points increase in target's union membership (equivalent to moving from the 25th to the 75th percentile of Target Union) is associated with 1.15 percentage points increase in target's offer premium. This is a substantial amount as the median for Combined CAR is about $1.3 \%$. On the contrary, Target Union is negatively associated with target's abnormal gains relative to the acquirer. The point estimate of -0.067 implies that a 10 percentage points increase in target's union membership leads to a target capturing an additional 0.67 percentage points of combined target and acquirer pre-merger market value. In dollar terms, this additional gain is about $\$ 8.6$ million for median-sized targets and acquirers. Target-Acquirer Union does not seem to have a significant impact on neither total synergy gains nor target's abnormal share of gains relative to acquirer.

The results on other control variables from the two tables are mostly consistent with findings in the prior literature. Offer premium is lower if the transaction is financed by cash and also lower if the acquirer entirely uses stocks as payment. Cash mergers generate more synergy gains while stock mergers generate negative amounts of synergies. The acquiring firm's shareholders gain more from the transaction if it pays for the target solely using cash. Small target firms receive higher premiums and large acquirers tend to offer higher premiums. Mergers that involve large firms acquiring large targets are most detrimental to the acquiring firm's shareholder value. In cases when relatively smaller firms acquiring relatively large target firms create more total synergies with more of the synergy benefits being captured by the target firm.

In sum, the results indicate that the target firm's union strength and to a lesser extent, target-acquirer union strength difference help explain the merging firm's announcement returns. A statistically robust and economically significant finding is that target's union 
strength has a positive impact on target's premium, on gains to acquirer, and on the total synergy benefits that the merger creates. The difference between target's and acquirer's union strength has a negative effect on target's offer premiums. These results are consistent with the hypothesis that takeovers can potentially unlock the economic rents previously captured by the target firm's labor union.

\subsection{Effect of union strength on labor outcomes}

\subsubsection{Matching mergers to census establishment data}

The above findings establish a direct relation between firms' union strength and gains to shareholders. In this section, I focus on the impact of union on firm's operations following takeovers. In particular, I focus the analysis on labor outcomes because the primary function of union is to bargain with employers. To do so, I use information on wages and employment at the establishment-level from the Longitudinal Business Database (LBD), maintained at the U.S. Census Bureau. This section describes the sample.

The LBD is a longitudinal database of U.S. establishments and firms with paid employees. It is constructed from the Census Bureau's Business Register and enhanced with survey data collections. ${ }^{9}$ The LBD covers all sectors of the economy and currently runs from 1976 to $2005 .{ }^{10}$ Basic data items in the LBD include employment, payroll, four-digit Standard Industrial Classification (SIC) industry code, and first/last year of operation etc. I divide total payroll by the total employment to obtain annual wage per employee at an establishment.

The LBD assigns each establishment a permanent establishment identifier (LBDNUM) and a firm identifier (FIRMID). The LBDNUM is invariant to firm ownership changes. All the establishments owned by the same parent firm share a single FIRMID. For each merger deal, I use the target's CUSIP to match the census' "FIMRID" through a "Compustat-SSEL Bridge" file created by the Census the year prior to the completion year. About $70 \%$ of deals are matched which left me with 4,138 deals. Table 3.3 shows the number of matched

\footnotetext{
${ }^{9}$ See Jarmin and Miranda (2002) for a detailed description of the LBD.

${ }^{10}$ Currently, the latest year in the LBD is 2005. Therefore, I focus on mergers completed by 2002 to have a three-window after a takeover.
} 
deals across time. The time period from 1981 to 2002 covers two cycles in M\&A waves. The number of transactions begins to increase in the 1980s, peaks in the late 1980s, and declines in the early 1990s before picking up again toward the end of the sample period.

Once I identify target firms, I use the firm-establishment links to identify all the establishments owned by target firms one year immediately before the merger. I rely on the LBDNUM to follow these establishments longitudinally. I choose a three-year window before and after the acquisition to track the wage and employment path of the target establishments.

\subsubsection{Descriptive statistics}

I report descriptives statistics for key variables at the target firm/plant level in Table 3.4. Immediately before a takeover, a typical target firm owns 63 establishments and employs about 3,244 employees. The average wage per worker is about 42,705 dollars (expressed in 2005 real dollars). A substantial sample attrition can be seen from the second column of the table. For instance, for the year immediately prior to the merger, denoted as T-1, I am able to match 4,149 target firms, however, only 3,187 of these firms still exist three years after the merger. Recall that I match firms by FIRMID at T-1, obtain the establishment identifier LBDNUM and follow these LBDNUMs over time. This means that for 962 deals, I cannot find any establishment left in the LBD at $\mathrm{T}+3$ that was originally owned by the targeted firm. For these remaining 3,187 firms, 58 out of the 63 establishments are left. They employ 3,187 workers and each worker earns a little less than 30,000 per year. The sample attrition is also evident from the plant counts shown in the second column in the bottom panel. Of all 246,616 establishments in T-1, less than 60 percent of them remain in the sample three years after the merger. The disappeared establishments are mostly likely being shut down.

At the firm level, average wage per worker experiences a gradual increase three years before reaching its peak at 48,159 at the time when the merger is completed. Wage level gradually declines post-takeover with a small dip in the first year and a big drop in the second year. Three years after the takeover, an average employee earns some 700 less than the year prior to the takeover. Average number of employees per firm, also sees steady increase in 
the periods leading up to the takeover before declining during the three-year course after the merger. Immediately before the takeover, a typical target firm employs 3,245 workers while at the third year after the takeover, the firm only employs 2,979 workers.

At the plant level, wage per worker first experiences slight increase preceding the takeover, it further decreases the first year post-takeover, it declines substantially the second year following the takeover, by more than $10 \%$. Three years after the takeover, an average employees makes about 3,000 dollars less than he or she used to make four years ago. The number of employees in a plants declines during the three-year period before the takeover, however, has picked up since the completion of the merger. The incongruence of firm and plant employment level mean values may be because relatively smaller establishments are being shut down within the target firms.

\subsubsection{Variables}

To capture the full spectrum of labor outcomes, I focus on four variables: Wage, employment, wage growth rate, and employment growth rate. I measure establishment-level wage and employment growth rates using the following formula:

$$
g(X)_{i t}=\frac{\left(X_{i t}-X_{i t-1}\right)}{\frac{1}{2}\left(X_{i t}+X_{i t-1}\right)}
$$

where $\mathrm{g}(\mathrm{X})$ is the growth rate of $\mathrm{X}$ from $\mathrm{t}-1$ to $\mathrm{t}$; $\mathrm{X}$ is wage or employment. This growth rate measure has become standard in the analysis of establishment and firm dynamics, because it shares some useful properties of log differences but also accommodates entry and exit (See Davis et al., 2009). By construction, this measure is bounded between -2 and +2 .

\subsubsection{Empirical methodology}

This section describes two key methodological choices in the empirical analysis.

\subsubsection{Control sample}

Before I analyze the impact of labor union on labor outcomes, I first estimate the effect of takeovers on target firm's labor outcomes. Acquirers do not choose target firms 
at random, however, which leads to a selection bias problem. When comparing the labor outcomes of acquired versus non-acquired establishments, it is important to select a control group closest to the counterfactuals. My basic approach is to choose a group of comparable establishments for each target establishment based on industry, age cohort, and the number of employees one year prior to the takeover year. Once I identify the control establishments, I use the LBDNUM to follow them before and after the merger year the same way that I keep track of the actual target establishments. The procedure is described below:

- I begin with all establishments that are owned by a public-listed firm and sort these establishments into three age cohorts: $0-4,5-9$ and $10+$ years old;

- In the year immediately before the takeover, I rank total number of employees with each three-digit-SIC-age group. From the pool of establishments that are not acquired the following year, I retain two immediately bigger and two immediately smaller than the targeted plant;

- After identifying all controls establishments, I follow them the same way I follow targeted plants before and after the merger as if they were targeted in an acquisition.

This approach enables me to compare the wage and employment paths for targets to comparable plants with the same observable characteristics in terms of industry, age, and size.

\subsubsection{Effect of takeover on wage and employment}

To quantify the effects of takeovers on wage and employment outcomes, I construct an unbalanced six-year panel and estimate a differences-in-differences model to compare changes between target and controls establishments. The specification is the following:

$$
Y_{i t}=\alpha+\beta_{1} \text { After }_{i t}+\beta_{2}\left(\text { Target* }^{*} \text { After }_{i t}\right)+\text { Plant FE } \text { Year FE }+\epsilon_{i t}
$$

In the above equation, the dependent variable $Y_{i t}$ includes annual wage per worker, wage growth rate, employment, and employment growth rate. After is a dummy variable equal to one for three periods after and equal to zero for the three periods prior to the merger. 
Target is a dummy variable equal to one if the establishment is acquired by another firm at $\mathrm{T}$, and zero for control plants.

Results are reported in Table 3.5. The coefficient on the interaction term between Target and After can be interpreted as the difference in labor outcomes between three years before the merger and three years after the merger for targets relative to control establishments. As can be seen across all four columns, $\beta_{2}$ is negative and statistically significant. This indicates the acquired plants not only exhibit lower wage and employment levels, but also grow less faster in wage and employment relative to control establishments. On average, three years after the merger, the acquired plants pay $0.7 \%$ lower to their workers and employ $1.8 \%$ fewer workers than control establishments. Furthermore, the grow rates in wage and employment are also lower, by about $0.3 \%$ and $0.4 \%$, respectively. I check the robustness of this results using an employment-weighted regression. Point estimates are very similar. These results suggest that the target firm's employees fare much worse following a takeover, both in terms of wage growth and job security. These results are consistent with the predictions in Shleifer and Summers (1988) and Pagano and Volpin (2005).

\subsubsection{Union and Right-to-work laws}

The above results suggest that workers in the target firms are adversely affected by takeovers. Labor unions represent its members in collective contract bargaining over wage and employment with firms' management teams. A related question is whether labor unions can mitigate these negative effects on workers. Simply adding unionization variable in the regression might not identify the true effect of union on wage and employment because firm's union status is not random. Unions could organize at highly profitable firm/plants that are more likely to grow and pay higher wages. In order to identify the effect of union, I exploit variations in bargaining environment that potentially matters for the strength of union power. I consider whether the plant is located in Right-to-Work (RTW) law state. States without such laws are generally considered a more favorable bargaining environment for labor unions. I briefly describe the institutional background of Right-to-work laws.

Essentially, a RTW law makes it illegal to force someone to join a union as a condition of employment at a workplace. The original intent of these laws was to weaken unions. 
Unions complain that this creates a free-rider problem since covered employees can enjoy the benefits of collective bargaining without paying the cost. Hence, if one lives in a state without RTW laws and one's employer is unionized, one would be required to join the union or at least pay union dues. The employee would also be represented by the union and bound by the union's contract. On the other hand, if one lives in a RTW state and ones workplace is unionized, one would still be represented by the union and bound by the union contract, but would not be required to join the union or pay union dues. Such laws are associated with significantly lower levels of union membership, which is why unions so strongly oppose them. As can be seen from the top panel in Figure 1, the unweighted mean union membership as a percentage of workers for the 50 states was about 4 percent for right-to-work states in 2005, less than one-half the 9 percent rate for states without such laws. Clearly, RTW states on average have much lower union presence and the gap between RTW and non-RTW states is not closing.

As of April, 2011, 22 states have Right-to-work laws and most of them adopted the law in the 1940's and 1950's after the passage of the Taft-Hartley Act of 1947. ${ }^{11}$ Figure 2 depicts the maps of these 22 states and Figure 3 lists the years these laws are enacted. Studies by Farber (1984) and by Ellwood and Fine (1987) have established both economic and psychological channels that RTW laws weaken the union's bargaining position, reduce the expected benefits of union membership, and ultimately diminish union membership by $5-10 \%$. Recent literature exploit the variation of RTW laws across states. For instance, Chen, Kacperczyk, and Ortiz-Molina (2009) use state's RTW laws to measure the toughness of bargaining environment. Matsa (2010) exploit state's adoption of RTW laws in the 1950s as an exogeous source of variations in union bargaining power.

These observations imply that in RTW states where labor unions face a less favorable bargaining environment, their roles are relatively limited compared with states without such laws. I therefore create an interaction term between union membership and an indicator variable for Right-to-work law. The interpretation of this interaction term is analogous to

\footnotetext{
${ }^{11}$ Section $14(\mathrm{~b})$ of this act gave states the legal power to pass right-to-work laws.After the Taft-Hartley Act, more states passed right-to-work laws, with most of the legislation enacted in the late 1940s and 1950s. The few exceptions are: Indiana, in 1965, repealed the right-to-work law it had passed in 1957; Louisiana passed its right-to-work law in 1976; Idaho passed its law in 1986 and Oklahoma passed its law in 2001.
} 
Rajan and Zingales (1998) $)^{12}$ and the identification strategy is to identify whether the effect of union on post-merger labor outcomes vary across establishments in RTW states from those in states without such laws.

\subsubsection{Impact of union}

In this section, I consider the role union plays in mitigating the negative effects in the following regression framework:

$$
\begin{aligned}
Y_{i j t} & =\alpha+X \gamma+\beta_{1} \text { After }_{i t}+\beta_{2} \text { Union }_{j t} \\
& +\beta_{3}\left(\text { After }_{i t} * \operatorname{Union}_{j t}\right)+\beta_{4}\left(\text { After }_{i t} * \mathrm{RTW}_{i}\right) \\
& +\beta_{5}\left(\mathrm{Union}_{j t} * \mathrm{RTW}_{i}\right)+\beta_{6}\left(\text { After }_{i t} * \mathrm{Union}_{j t} * \mathrm{RTW}_{i}\right) \\
& + \text { Plant FE }+ \text { Year FE }+\epsilon_{i j t}
\end{aligned}
$$

In the above equation, $Y_{i j t}$ is the labor outcome for establishment $\mathrm{i}$, in industry $\mathrm{j}$ at year t. After is a dummy variable equal to one for three periods after and equal to zero for the three periods prior to the merger. Union is the portion of workers who are union members in industry $\mathrm{j}$ at year t. $R T W$ is an indicator variable equal to one if the establishment $\mathrm{i}$ is in located in a state with Right-to-work laws. The triple interaction term between After, Union, and $R T W$ identifies the effect of union membership on the labor outcomes for establishments located in RTW state after a takeover. All the two-way interaction terms are included in the equation.

Table 3.6 presents results on the effects of labor union on wage and wage growth. Column (1) and (4) show that higher union power is associated with higher wage and wage growth rate. Other things equal, a $10 \%$ increase in union membership increases the wage level by nearly $0.9 \%$ and the wage growth rate by $1.2 \%$. Column (2) and (5) further add an interaction term between After and Union. In column (2), the coefficient on this variable is negative, and the point estimate is larger than the point estimate on Union itself. This implies that after the takeover, establishments with higher union power actually are

\footnotetext{
${ }^{12}$ The authors identify the effect of financial development on economic growth by examining whether industries need more external financing grow faster in countries with more developed financial markets which facilitate external financing.
} 
associated with lower wages. This variable is also negative for wage growth rate although not statistically significant at a conventional confidence level. Column (3) and (6) estimate the full model. The coefficients on the triple interaction term are both negative for wage and wage growth. Back-of-the-envelope calculation indicates that, other things equal, wage growth in an establishment located in a state with RTW law is slowed down by about $0.2 \%$ relative to an establishment located in a non-right-to-work law state, assuming the both establishments operate in an industry with $10 \%$ of its workers unionized; the comparable estimate for wage is about $1 \%$ lower. The negative sign on the triple term means that after the merger, the adverse effects of union on wage and wage growth are magnified in states where labor unions face a less favorable bargaining environment.

Table 3.7 reports estimation results using employment and employment growth as dependent variables. According to the results, union density is inversely associated with employment and employment growth. A 10\% increase in union membership is associated with $0.7 \%$ less employment and $0.5 \%$ slower employment growth rate. The triple interaction term is negative and statistically significant for employment level but positive and statistically insignificant for employment growth rate. In column (3), between two establishments in an industry with $10 \%$ unionized workers, an establishment located in a Right-to-work law state employs $5 \%$ fewer employees relative to an otherwise-same establishment in a state without such laws.

These results imply that effects of labor unions on wages and employment are particularly weakened in places where the union faces a less favorable bargaining environment and especially after the takeover when the labor union is disadvantaged. To some extent, this evidence is consistent with the view that takeovers undermine the power of labor union and reduce wages and employment. Combining this interpretation with prior results on shareholder values, my results suggest that acquirers unlock the prior rents captured by the union and therefore benefit the shareholders. 


\subsection{Conclusions and future research}

Labor unions play a critical role in affecting merger outcomes in practice but systematic academic evidence thus far is limited. In this study, I provide large-sample empirical evidence on the impact of labor union in takeovers. I consider the effect of labor union on two major groups of stakeholders in the merging firms: the shareholders and the average employees.

I find that the target firm's union strength and the target-acquirer union strength difference help explain the merging firm's announcement returns. According to my results, target's union strength has a positive impact on target's premium, gains to acquirer, and the total synergy benefits that the merger creates. The difference between target's and acquirer's union strength has a negative effect on target's offer premiums. These results are consistent with the hypothesis that takeovers can potentially unlock the economic rents previously captured by the target firm's labor union. The results are also consistent with the argument that target-acquirer union strength difference can affect the post-merger integration which helps to realize of merger gains.

To help understand the underlying mechanism that explain the connection between union power and merger gains, I consider the effect of target's union power on employees' wages and employment subsequent to mergers, using establishment-level data from the U.S. Census Bureau. I find that, in a three-year window after a takeover, the wages and employment level for the target establishments are lowered by $3.5 \%$ and $2 \%$, and the growth rates in wage and employment are reduced by about $2 \%$, compared with three years prior to the takeover. I further compare the wage and employment outcomes between the target establishments and comparable establishments with similar industry, age and employment characteristics. The results show that target establishments exhibit net decline in wage and employment relative to the control establishments.

I further show that higher union density is associated with worsened outcomes in wage growth and employment growth. I identify the effect of union on labor outcomes by considering the cross-sectional variation in union bargaining environment — whether a plant is located in a state with Right-to-work laws. The empirical results indicate that effects 
of labor unions on wages and employment are particularly weakened in places where the union faces a less favorable bargaining environment and especially after the takeover when the labor union is disadvantaged.

Putting all these pieces of evidence together, my results show that takeovers undermine the power of labor union and reduce wages and employment. The acquirers restructure the target firm, unlock the prior rents captured by the union, and ultimately benefit the shareholders. A related yet unexplored question is how labor unions affect productivity. As in Chapter 2, I show that shareholder gains are coming from productivity improvements instead of wealth transfers from employees. In the future, I plan to investigate whether labor unions affect gains from mergers through their impacts on productive efficiencies. 
Table 3.1: The Effect of Union Power on Target and Acquirer's shareholder gains

The table reports estimates of a firm-level OLS regression explaining the offer premium and acquirer CAR. The sample consists of mergers from the SDC M\&As database in which the announcement date is between 1984 and 2009, the completion date is within 1000 days of the announcement, and both the target and the acquirer are publicly-listed firms. Offer premium is the ratio of transaction value to the target's market value 30 trading days before announcement. Acquirer's CAR is the three-day cumulative abnormal returns which are estimated using a market model adjusting for CRSP value-weighted market index. Target Union is the fraction of unionized workers for the industry in which the target firm operates. Target-Acquirer Union is the difference between Target's Union and Acquirer's Union. Cash is a dummy variable that equals one if the entire transaction value was paid by cash and zero otherwise. Stock is a dummy variable that equals one if the entire transaction was paid by stock and zero otherwise. Related is a dummy variable that equals one if target and acquirer share the same primary 2-digit SIC industry. Target(Acquirer) size is the logarithm of target's (acquirer) market value two days before announcement. Heteroskedastic-robust standard errors are in parentheses. The symbols ***, **, and * indicate statistical significance at the 1, 5, and 10 percent levels, respectively.

\begin{tabular}{|c|c|c|c|c|c|c|}
\hline & \multicolumn{3}{|c|}{ Offer Premium } & \multicolumn{3}{|c|}{ Acquirer CAR } \\
\hline & (1) & $(2)$ & $(3)$ & $(4)$ & $(5)$ & (6) \\
\hline \multirow[t]{2}{*}{ Target Union } & $2.232^{* * *}$ & $2.586^{* * *}$ & $2.250^{* * *}$ & $0.091^{* * *}$ & $0.098^{* * *}$ & $0.114^{* * *}$ \\
\hline & $(0.519)$ & $(0.524)$ & $(0.900)$ & $(0.022)$ & $(0.022)$ & $(0.038)$ \\
\hline \multirow[t]{2}{*}{ Target-Acquirer Union } & $-1.562^{* *}$ & $-1.429^{* *}$ & $1.597^{* *}$ & -0.033 & -0.033 & -0.045 \\
\hline & $(0.639)$ & $(0.637)$ & $(0.716)$ & $(0.027)$ & $(0.027)$ & $(0.031)$ \\
\hline \multirow[t]{2}{*}{ Cash } & & $-0.676^{* * *}$ & $-0.559^{* * *}$ & & $0.018^{* * *}$ & $0.017^{* *}$ \\
\hline & & $(0.151)$ & $(0.158)$ & & $(0.006)$ & $(0.007)$ \\
\hline \multirow[t]{2}{*}{ Stock } & & $-0.573^{* * *}$ & $-0.534^{* * *}$ & & -0.006 & -0.002 \\
\hline & & $(0.131)$ & $(0.138)$ & & $(0.006)$ & $(0.006)$ \\
\hline \multirow[t]{2}{*}{ Related } & & -0.058 & -0.125 & & 0.003 & 0.002 \\
\hline & & $(0.119)$ & $(0.134)$ & & $(0.005)$ & $(0.006)$ \\
\hline \multirow[t]{2}{*}{ Tender offer } & & 0.012 & -0.082 & & 0.006 & 0.010 \\
\hline & & $(0.156)$ & $(0.171)$ & & $(0.007)$ & $(0.007)$ \\
\hline \multirow[t]{2}{*}{ Acquirer Size } & & $0.248^{* * *}$ & $0.224^{* * *}$ & & $-0.004^{* *}$ & $-0.004^{* *}$ \\
\hline & & $(0.039)$ & $(0.040)$ & & $(0.002)$ & $(0.002)$ \\
\hline \multirow[t]{2}{*}{ Target Size } & & $-0.392^{* * *}$ & $-0.393^{* * *}$ & & $-0.006^{* * *}$ & $-0.007^{* * *}$ \\
\hline & & $(0.042)$ & $(0.046)$ & & $(0.002)$ & $(0.002)$ \\
\hline Industry FE & & & Yes & & & Yes \\
\hline Year FE & & & Yes & & & Yes \\
\hline \multirow[t]{2}{*}{ Constant } & $0.668^{* * *}$ & $2.356^{* * *}$ & $2.355^{* * *}$ & $-0.023^{* * *}$ & $0.102^{* * *}$ & $0.061^{* *}$ \\
\hline & $(0.075)$ & $(0.412)$ & $(0.657)$ & $(0.003)$ & $(0.018)$ & $(0.028)$ \\
\hline Observations & 1937 & 1932 & 1932 & 1939 & 1933 & 1933 \\
\hline $\mathrm{R}^{2}$ & 0.01 & 0.07 & 0.11 & 0.01 & 0.05 & 0.09 \\
\hline
\end{tabular}


Table 3.2: The Effect of Union Power on Combined CAR and Target's Share of Gains

The table reports estimates of a firm-level OLS regression explaining the combined CAR and target's gains relative to the acquirer's. The sample consists of mergers from the SDC M\&As database in which the announcement date is between 1984 and 2009, the completion date is within 1000 days of the announcement, and both the target and the acquirer are publiclylisted firms. Combined CAR is the market-value weighted average of target's CAR and acquirer's CAR. The three-day cumulative abnormal returns are estimated using a market model adjusting for CRSP value-weighted market index. Target's Gains - Acquirer's Gains is the difference of dollar abnormal returns between target and acquirer, scaled by the sum of tow firms' market value. Target Union is the fraction of unionized workers for the industry in which the target firm operates. Target-Acquirer Union is the difference between Target's Union and Acquirer's Union. Cash is a dummy variable that equals one if the entire transaction value was paid by cash and zero otherwise. Stock is a dummy variable that equals one if the entire transaction was paid by stock and zero otherwise. Related is a dummy variable that equals one if target and acquirer share the same primary 2-digit SIC industry. Target(Acquirer) size is the logarithm of target's (acquirer) market value two days before announcement. Heteroskedastic-robust standard errors are in parentheses. The symbols ${ }^{* * *}, * *$, and $*$ indicate statistical significance at the 1, 5, and 10 percent levels, respectively.

\begin{tabular}{|c|c|c|c|c|c|c|}
\hline & \multicolumn{3}{|c|}{ Combined CAR } & \multicolumn{3}{|c|}{ Target - Acquirer Gains } \\
\hline & (1) & $(2)$ & $(3)$ & (4) & $(5)$ & $(6)$ \\
\hline \multirow[t]{2}{*}{ Target Union } & $0.115^{* * *}$ & $0.074^{* * *}$ & $0.098^{* * *}$ & -0.025 & $-0.067^{* * *}$ & $-0.067^{* * *}$ \\
\hline & $(0.021)$ & $(0.021)$ & $(0.035)$ & $(0.018)$ & $(0.017)$ & $(0.030)$ \\
\hline \multirow[t]{2}{*}{ Target-Acquirer Union } & 0.002 & -0.004 & -0.019 & $0.049^{* *}$ & 0.036 & 0.036 \\
\hline & $(0.026)$ & $(0.025)$ & $(0.028)$ & $(0.022)$ & $(0.021)$ & $(0.023)$ \\
\hline \multirow[t]{2}{*}{ Cash } & & $0.015^{* *}$ & $0.013^{* *}$ & & $-0.011^{* *}$ & $-0.013^{* *}$ \\
\hline & & $(0.006)$ & $(0.006)$ & & $(0.005)$ & $(0.005)$ \\
\hline \multirow[t]{2}{*}{ Stock } & & $-0.019^{* * *}$ & $-0.016^{* * *}$ & & -0.004 & -0.006 \\
\hline & & $(0.005)$ & $(0.005)$ & & $(0.004)$ & $(0.005)$ \\
\hline \multirow[t]{2}{*}{ Related } & & 0.007 & 0.007 & & 0.004 & 0.004 \\
\hline & & $(0.005)$ & $(0.005)$ & & $(0.004)$ & $(0.004)$ \\
\hline \multirow[t]{2}{*}{ Tender offer } & & $0.023^{* * *}$ & $0.027^{* * *}$ & & $0.015^{* * *}$ & $0.012^{* *}$ \\
\hline & & $(0.006)$ & $(0.007)$ & & $(0.005)$ & $(0.006)$ \\
\hline \multirow[t]{2}{*}{ Acquirer Size } & & $-0.021^{* * *}$ & $-0.021^{* * *}$ & & $-0.016^{* * *}$ & $-0.016^{* * *}$ \\
\hline & & $(0.002)$ & $(0.002)$ & & $(0.001)$ & $(0.001)$ \\
\hline \multirow[t]{2}{*}{ Target Size } & & $0.012^{* * *}$ & $0.012^{* * *}$ & & $0.020^{* * *}$ & $0.020^{* * *}$ \\
\hline & & $(0.002)$ & $(0.002)$ & & $(0.001)$ & $(0.001)$ \\
\hline Industry FE & & & Yes & & & Yes \\
\hline Year FE & & & Yes & & & Yes \\
\hline \multirow[t]{2}{*}{ Constant } & $0.012^{* * *}$ & $0.149^{* * *}$ & $0.104^{* * *}$ & $0.049^{* * *}$ & $0.031^{* *}$ & $0.045^{* *}$ \\
\hline & $(0.003)$ & $(0.016)$ & $(0.026)$ & $(0.003)$ & $(0.014)$ & $(0.022)$ \\
\hline Observations & 1933 & 1933 & 1933 & 1933 & 1933 & 1933 \\
\hline $\mathrm{R}^{2}$ & 0.02 & 0.13 & 0.17 & 0.01 & 0.11 & 0.16 \\
\hline
\end{tabular}


Table 3.3: Number of Takeovers Matched to LBD

This table reports the number of mergers in my study. I obtain from the SDC M\&A database a sample of acquisitions in which the announcement date is between 1981 and 2002, the completion date is within 360 days of the announcement, and the acquisition target is a domestic U.S. firm. Column 2 reports the number of transactions in the SDC Platinum that meet all criteria. Column 3 reports the number of these transactions that were able to be matched to the Longitudinal Business Database (LBD) maintained at the U.S. Census Bureau.

\begin{tabular}{ccc}
\hline Year & Deals in SDC & Deals matched to LBD \\
\hline 1981 & 37 & 29 \\
1982 & 63 & 38 \\
1983 & 77 & 56 \\
1984 & 143 & 104 \\
1985 & 144 & 112 \\
1986 & 226 & 181 \\
1987 & 204 & 158 \\
1988 & 271 & 217 \\
1989 & 224 & 167 \\
1990 & 159 & 125 \\
1991 & 96 & 70 \\
1992 & 117 & 79 \\
1993 & 156 & 107 \\
1994 & 215 & 174 \\
1995 & 287 & 228 \\
1996 & 378 & 281 \\
1997 & 438 & 333 \\
1998 & 506 & 378 \\
1999 & 539 & 443 \\
2000 & 500 & 388 \\
2001 & 395 & 319 \\
2002 & 205 & 162 \\
\hline Total & 5380 & 4149 \\
\hline
\end{tabular}


Table 3.4: Descriptive Statistics

The table reports summary statistics for some variables at the target firm and plant level. The sample consists of mergers from the SDC M\&As database in which the announcement date is between 1981 and 2002, the completion date is within 360 days of the announcement, and the target is a publicly-listed firm that can be matched to the LBD, maintained at U.S. Census Bureau. $\mathrm{T}$ is the year when the merger is completed. Average Wage is calculated as total annual payroll divided by total number of employees, expressed in 2005 US dollars. Employment is the total number of employees.

\begin{tabular}{|c|c|c|c|c|c|c|c|}
\hline \multirow[b]{2}{*}{ Timing } & \multirow[b]{2}{*}{$\mathrm{N}$} & \multicolumn{2}{|c|}{ Average Wage } & \multicolumn{2}{|c|}{ Total Employment } & \multicolumn{2}{|c|}{ Plants per firm } \\
\hline & & Mean & $\mathrm{SD}$ & Mean & $\mathrm{SD}$ & Mean & $\mathrm{SD}$ \\
\hline $\mathrm{T}-3$ & 4042 & 38201.7 & 27784.5 & 2944.7 & 10723.9 & 52.7 & 197.7 \\
\hline $\mathrm{T}-2$ & 4089 & 40816.4 & 31645.4 & 3105.0 & 11357.6 & 57.6 & 217.1 \\
\hline $\mathrm{T}-1$ & 4149 & 42704.9 & 34039.3 & 3244.5 & 11982.6 & 62.8 & 238.8 \\
\hline $\mathrm{T}$ & 4142 & 48159.1 & 49504.4 & 3124.6 & 11082.3 & 63.1 & 239.4 \\
\hline $\mathrm{T}+1$ & 3960 & 46398.9 & 44090.8 & 2972.3 & 10618.9 & 61.0 & 224.3 \\
\hline $\mathrm{T}+2$ & 3406 & 41873.4 & 33064.7 & 3084.1 & 10802.2 & 61.0 & 216.5 \\
\hline $\mathrm{T}+3$ & 3187 & 42001.2 & 31483.4 & 2979.2 & 10650.5 & 57.2 & 207.0 \\
\hline \multicolumn{8}{|c|}{ Plant Level } \\
\hline & \multicolumn{3}{|c|}{ Average Wage } & \multicolumn{2}{|c|}{ Employment } & & \\
\hline Timing & $\mathrm{N}$ & Mean & $\mathrm{SD}$ & Mean & SD & & \\
\hline $\mathrm{T}-3$ & 201480 & 34531.4 & 26486.9 & 55.7 & 241.6 & & \\
\hline $\mathrm{T}-2$ & 223351 & 35275.9 & 27971.0 & 53.5 & 230.3 & & \\
\hline $\mathrm{T}-1$ & 246616 & 35971.4 & 29633.5 & 51.1 & 223.4 & & \\
\hline $\mathrm{T}$ & 223402 & 35651.9 & 30773.0 & 53.6 & 232.0 & & \\
\hline $\mathrm{T}+1$ & 192351 & 35327.3 & 29815.4 & 54.9 & 228.4 & & \\
\hline $\mathrm{T}+2$ & 170614 & 31667.7 & 28155.2 & 56.5 & 237.2 & & \\
\hline $\mathrm{T}+3$ & 149803 & 32815.9 & 27621.8 & 58.1 & 234.5 & & \\
\hline
\end{tabular}


Table 3.5: The Effect of Takeovers on Wage and Employment

The table reports estimates of a plant-level differences-in-differences regression of $\log \left(Y_{i t}\right)=$ $\alpha+\beta_{1}$ After $_{t}+\beta_{2}\left(\right.$ After $_{t} *$ Target $\left._{i}\right)+$ Plant \& Year FE $+\epsilon_{i t}$. The sample consists of mergers from the SDC M\&As database in which the announcement date is between 1981 and 2002, the completion date is within 360 days of the announcement, and the target is a publiclylisted firm that can be matched to the LBD, maintained at U.S. Census Bureau. Wage is calculated as total payroll divided by total number of employees. Employment is the total number of employees. All these two variables are in logs. Wage Growth (Employment Growth) is the change in wage (employment) over the previous year, scaled by the sum of this year and last year's wage (employment). The data are an unbalanced six-year panel $(\mathrm{T}-3, \mathrm{~T}-2, \mathrm{~T}-1, \mathrm{~T}+1, \mathrm{~T}+2$, and $\mathrm{T}+3)$ for target and control plants. $\mathrm{T}$, the year when the merger is completed, is dropped out from the analysis. After is a dummy variable that equals one for year $\mathrm{T}+1, \mathrm{~T}+2$, and $\mathrm{T}+3$, and zero for $\mathrm{T}-1, \mathrm{~T}-2$, and $\mathrm{T}-3$. Target is a dummy variable that equals one if an establishment's parent firm is acquired at year $\mathrm{T}$ and zero if an establishment is a control establishment. The control sample is constructed by selecting plants that are comparable to target establishments in terms of industry, age cohorts, and size prior to the takeover. Heteroskedastic-robust standard errors clustered at firm level are in parentheses. The symbols ${ }^{* * *},{ }^{* *}$, and ${ }^{*}$ indicate statistical significance at the 1,5 , and 10 percent levels, respectively.

\begin{tabular}{|c|c|c|c|c|}
\hline & $\begin{array}{l}\text { Wage } \\
(1)\end{array}$ & $\begin{array}{l}\text { Wage Growth } \\
\qquad(2)\end{array}$ & $\begin{array}{c}\text { Employment } \\
(3)\end{array}$ & $\begin{array}{c}\text { Employment Growth } \\
(4)\end{array}$ \\
\hline After & $\begin{array}{c}-0.026^{* * *} \\
(0.001)\end{array}$ & $\begin{array}{c}-0.014^{* * *} \\
(0.001)\end{array}$ & $\begin{array}{c}-0.001 \\
(0.001)\end{array}$ & $\begin{array}{l}-0.013 \\
(0.001)^{* * *}\end{array}$ \\
\hline Target*After & $\begin{array}{c}-0.007^{* * *} \\
(0.001)\end{array}$ & $\begin{array}{c}-0.003^{* * *} \\
(0.001)\end{array}$ & $\begin{array}{c}-0.018^{* * *} \\
(0.001)\end{array}$ & $\begin{array}{c}-0.004^{* * *} \\
(0.001)\end{array}$ \\
\hline Log(employment) & $\begin{array}{c}-0.182^{* * *} \\
(0.001)\end{array}$ & $\begin{array}{c}-0.177^{* * *} \\
(0.001)\end{array}$ & & $\begin{array}{l}0.432^{* * *} \\
(0.001)\end{array}$ \\
\hline Constant & $\begin{array}{l}10.873^{* * *} \\
(0.005)\end{array}$ & $\begin{array}{l}0.562^{* * *} \\
(0.005)\end{array}$ & $\begin{array}{l}2.819^{* * *} \\
(0.007)\end{array}$ & $\begin{array}{c}-1.166^{* * *} \\
(0.005)\end{array}$ \\
\hline Year FE & Yes & Yes & Yes & Yes \\
\hline Plant FE & Yes & Yes & Yes & Yes \\
\hline Observations & 4536928 & 4317349 & 4536928 & 4317349 \\
\hline $\mathrm{R}^{2}$ & 0.85 & 0.55 & 0.90 & 0.36 \\
\hline
\end{tabular}


Table 3.6: The Effect of Union on Wage and Wage Growth

The table reports estimates of Equation (3.4) in the main text. The sample consists of mergers from the SDC M\&As database in which the announcement date is between 1981 and 2002, the completion date is within 360 days of the announcement, and the target is a publicly-listed firm that can be matched to the LBD, maintained at U.S. Census Bureau. Wage is calculated as total payroll divided by total number of employees. Employment is the total number of employees. All these two variables are in logs. Wage Growth is the change in wage over the last year, scaled by the sum of this year and previous year's wage. The data are an unbalanced six-year panel $(\mathrm{T}-3, \mathrm{~T}-2, \mathrm{~T}-1, \mathrm{~T}+1, \mathrm{~T}+2$, and $\mathrm{T}+3)$ for target and control plants. $\mathrm{T}$, the year when the merger is completed, is dropped out from the analysis. After is a dummy variable that equals one for year $\mathrm{T}+1, \mathrm{~T}+2$, and $\mathrm{T}+3$, and zero for $\mathrm{T}-1, \mathrm{~T}-2$, and $\mathrm{T}-3$. Target is a dummy variable that equals one if an establishment's parent firm is acquired at year $\mathrm{T}$ and zero if an establishment is a control establishment. Union is the percent of unionized workers in the industry in which the target plant operates. RTW is a dummy variable equal to one if the target plant is located in state with Right-to-work laws and zero otherwise. The control sample is constructed by selecting plants that are comparable to target establishments in terms of industry, age cohorts, and size prior to the takeover. Heteroskedastic-robust standard errors clustered at firm level are in parentheses. The symbols ${ }^{* * *},{ }^{* *}$, and ${ }^{*}$ indicate statistical significance at the 1,5 , and 10 percent levels, respectively.

\begin{tabular}{|c|c|c|c|c|c|c|}
\hline & \multicolumn{3}{|c|}{ Wage } & \multicolumn{3}{|c|}{ Wage Growth } \\
\hline & (1) & $(2)$ & $(3)$ & $(4)$ & $(5)$ & $(6)$ \\
\hline \multirow[t]{2}{*}{ After } & $-0.012^{* * *}$ & $-0.006^{* * *}$ & $-0.011^{* * *}$ & $0.001^{* * *}$ & 0.001 & $-0.005^{* *}$ \\
\hline & $(0.002)$ & $(0.002)$ & $(0.003)$ & $(0.002)$ & $(0.002)$ & $(0.002)$ \\
\hline \multirow[t]{2}{*}{ Log(Employment) } & $-0.220^{* * *}$ & $-0.220^{* * *}$ & $-0.215^{* * *}$ & $-0.208^{* * *}$ & $-0.208^{* * *}$ & $-0.208^{* * *}$ \\
\hline & $(0.003)$ & $(0.003)$ & $(0.003)$ & $(0.002)$ & $(0.002)$ & $(0.002)$ \\
\hline \multirow[t]{2}{*}{ Union } & $0.085^{* * *}$ & $0.075^{* *}$ & -0.033 & $0.117^{* * *}$ & $0.116^{* *}$ & $0.055^{*}$ \\
\hline & $(0.025)$ & $(0.025)$ & $(0.038)$ & $(0.023)$ & $(0.023)$ & $(0.034)$ \\
\hline \multirow[t]{2}{*}{ After*Union } & & $-0.100^{* * *}$ & -0.018 & & -0.009 & $0.050^{* * *}$ \\
\hline & & $(0.013)$ & $(0.016)$ & & $(0.010)$ & $(0.014)$ \\
\hline \multirow[t]{2}{*}{ RTW*Union } & & & $0.089^{*}$ & & & $0.136^{* * *}$ \\
\hline & & & $(0.050)$ & & & $(0.043)$ \\
\hline \multirow[t]{2}{*}{ After*RTW } & & & 0.004 & & & $0.015^{* * *}$ \\
\hline & & & $(0.003)$ & & & $(0.003)$ \\
\hline \multirow[t]{2}{*}{ After*RTW*union } & & & -0.102 & & & $-0.153^{* * *}$ \\
\hline & & & $(0.026)$ & & & $(0.021)$ \\
\hline \multirow[t]{2}{*}{ Constant } & $10.758^{* * *}$ & $10.756^{* * *}$ & $9.757^{* * *}$ & $12.1829^{* * *}$ & $10.206^{* * *}$ & $0.093^{* * *}$ \\
\hline & $(0.012)$ & $(0.012)$ & $(0.035)$ & $(0.088)$ & $(0.009)$ & $(0.012)$ \\
\hline Year FE & Yes & Yes & Yes & Yes & Yes & Yes \\
\hline Plant FE & Yes & Yes & Yes & Yes & Yes & Yes \\
\hline Observations & 717502 & 717502 & 717502 & 690471 & 690471 & 690471 \\
\hline $\mathrm{R}^{2}$ & 0.84 & 0.84 & 0.85 & 0.59 & 0.59 & 0.59 \\
\hline
\end{tabular}


Table 3.7: The Effect of Union on Employment and Employment Growth

The table reports estimates of Equation (3.4) in the main text.. The sample consists of mergers from the SDC M\&As database in which the announcement date is between 1981 and 2002, the completion date is within 360 days of the announcement, and the target is a publicly-listed firm that can be matched to the LBD, maintained at U.S. Census Bureau. Wage is calculated as total payroll divided by total number of employees. Employment is the total number of employees. All these two variables are in logs. Employment Growth is the change in employment over the last year, scaled by the sum of this year and previous year's employment. The data are an unbalanced six-year panel $(\mathrm{T}-3, \mathrm{~T}-2, \mathrm{~T}-1, \mathrm{~T}+1$, $\mathrm{T}+2$, and $\mathrm{T}+3$ ) for target and control plants. $\mathrm{T}$, the year when the merger is completed, is dropped out from the analysis. After is a dummy variable that equals one for year $\mathrm{T}+1$, $\mathrm{T}+2$, and $\mathrm{T}+3$, and zero for $\mathrm{T}-1, \mathrm{~T}-2$, and $\mathrm{T}-3$. Target is a dummy variable that equals one if an establishment's parent firm is acquired at year $\mathrm{T}$ and zero if an establishment is a control establishment. Union is the percent of unionized workers in the industry in which the target plant operates. RTW is a dummy variable equal to one if the target plant is located in state with Right-to-work laws and zero otherwise. The control sample is constructed by selecting plants that are comparable to target establishments in terms of industry, age cohorts, and size prior to the takeover. Heteroskedastic-robust standard errors clustered at firm level are in parentheses. The symbols ***,**, and * indicate statistical significance at the 1, 5, and 10 percent levels, respectively.

\begin{tabular}{|c|c|c|c|c|c|c|}
\hline & \multicolumn{3}{|c|}{ Employment } & \multicolumn{3}{|c|}{ Employment Growth } \\
\hline & (1) & $(2)$ & $(3)$ & (4) & $(5)$ & $(6)$ \\
\hline After & $\begin{array}{c}-0.013^{\text {*** }} \\
(0.004)\end{array}$ & $\begin{array}{c}-0.023^{* * *} \\
(0.004)\end{array}$ & $\begin{array}{c}-0.023^{\text {*** }} \\
(0.005)\end{array}$ & $\begin{array}{c}-0.038^{* * *} \\
(0.002)\end{array}$ & $\begin{array}{c}-0.035^{\text {*** }} \\
(0.002)\end{array}$ & $\begin{array}{c}-0.031^{\text {*** }} \\
(0.003)\end{array}$ \\
\hline Log(Employment) & & & & $\begin{array}{l}0.501^{* * *} \\
(0.003)\end{array}$ & $\begin{array}{l}0.501^{* * *} \\
(0.003)\end{array}$ & $\begin{array}{c}0.501^{* * *} \\
(0.003)\end{array}$ \\
\hline Union & $\begin{array}{r}-0.067 \\
(0.043)\end{array}$ & $\begin{array}{c}-0.052^{* *} \\
(0.025)\end{array}$ & $\begin{array}{c}-0.541^{* * *} \\
(0.065)\end{array}$ & $\begin{array}{c}-0.051^{* *} \\
(0.025)\end{array}$ & $\begin{array}{c}-0.055^{* *} \\
(0.025)\end{array}$ & $\begin{array}{c}-0.049 \\
(0.037)\end{array}$ \\
\hline After*Union & & $\begin{array}{l}0.142^{* * *} \\
(0.023)\end{array}$ & $\begin{array}{l}0.103^{* * *} \\
(0.029)\end{array}$ & & $\begin{array}{c}-0.051^{* * *} \\
(0.013)\end{array}$ & $\begin{array}{c}-0.059^{* * *} \\
(0.017)\end{array}$ \\
\hline RTW*Union & & & $\begin{array}{c}-0.367^{* * *} \\
(0.085)\end{array}$ & & & $\begin{array}{c}-0.025 \\
(0.049)\end{array}$ \\
\hline After*Union & & & $\begin{array}{l}0.028^{* * *} \\
(0.005)\end{array}$ & & & $\begin{array}{c}-0.012^{* * *} \\
(0.003)\end{array}$ \\
\hline After*Union*RTW & & & $\begin{array}{c}-0.157^{* * *} \\
(0.046)\end{array}$ & & & $\begin{array}{c}0.021 \\
(0.026)\end{array}$ \\
\hline Constant & $\begin{array}{l}2.667^{\text {*** }} \\
(0.018)\end{array}$ & $\begin{array}{l}2.669^{* * *} \\
(0.082)\end{array}$ & $\begin{array}{l}2.081^{* * *} \\
(0.020)\end{array}$ & $\begin{array}{c}-1.325^{* * *} \\
(0.012)\end{array}$ & $\begin{array}{c}-1.326^{* * *} \\
(0.012)\end{array}$ & $\begin{array}{c}-1.327^{* * *} \\
(0.012)\end{array}$ \\
\hline Year FE & Yes & Yes & Yes & Yes & Yes & Yes \\
\hline Plant FE & Yes & Yes & Yes & Yes & Yes & Yes \\
\hline Observations & 717502 & 717502 & 717502 & 690471 & 690471 & 690471 \\
\hline $\mathrm{R}^{2}$ & 0.91 & 0.91 & 0.91 & 0.46 & 0.46 & 0.46 \\
\hline
\end{tabular}




\section{CHAPTER IV}

\section{Career Concerns and the Busy Life of Young CEOs}

\subsection{Introduction}

In this paper, we empirically examine how career concerns affect the investment activities of younger Chief Executive Officers (CEOs) compared to older CEOs. Career concerns matter because managers are expected to adjust their investment behavior to influence the labor market's perception of their abilities, and hence their reputation and future prospects. Indeed, the theoretical literature has long recognized that a firm's investment decisions are contaminated by its managers' career concerns (see, e.g., Holmstrom and Ricart i Costa, 1986; Prendergast and Stole, 1996; and Holmstrom, 1999). Yet, the limited available empirical evidence on career concerns is mostly about specialized labor markets, such as mutual fund managers (Chevalier and Ellison, 1999) security analysts (Hong, Kubik, and Solomon, 2000), and macroeconomists (Lamont, 2002). All of these studies find that younger decisionmakers avoid bold decisions, preferring to "herd" rather than stand out and risk a negative outcome that could adversely affect their careers. The effect of career concerns on CEOs making corporate real investment decisions has not been examined so far, and there is reason to question if they too will behave conservatively.

The serious downside, forced terminations, are relatively infrequent for CEOs compared to executives in the specialized labor markets (Weisbach, 1988; Huson, Parrino, and Starks, 2001; Jenter and Kanaan, 2010; Kaplan and Minton, 2010, and Taylor, 2010), even while there is significant upside potential for younger CEOs who successfully signal superior ability. For example, Gudell (2010) reports that there is a sizeable market for serial CEOs, along 
with large increases in compensation across jobs. Also, with their long career horizons to reap benefits, younger CEOs have strong incentives to boldly signal ability. Using comprehensive data from the U.S. Census Bureau, we study real investment activities across all sectors of the economy and address questions dealing with the impact of career concerns on three salient aspects of investment behavior: the extent and type of investments activities, the associated productive efficiency, and the favored internal capital allocations made by CEOs of different ages. This helps us better understand the investment distortions that arise out of career concerns, and ultimately the fundamental issue in corporate finance - what impedes capital from being allocated to its most efficient investment opportunity (Stein, 2003).

We start our analysis by examining the two main contrasting positions offered in the literature regarding how career concerns affect the investment behaviors of the younger versus older CEOs. In one position, a manager's career concerns may result in conservatism and underinvestment, as was first pointed out by Holmstrom (1982). The younger CEO, who does not have a track record to back him up, faces higher risks when making investment decisions and is likely to be perceived as incompetent if the investments turn out to be bad. Consequently, the younger CEO may shy away from making bold investments. Similarly, Scharfstein and Stein (1990) suggest that managers' career concerns, particularly for the younger CEOs, may lead them to avoid radical actions and to "herd" instead. We refer to these models as the Market Learning Models, since the driving force in these models is what the labor market can learn about CEO ability from the outcomes of their decisions.

In a contrasting position, modeled by Prendergast and Stole (1996), the younger CEO purposely adopts a more active investment strategy because of a difference in investment incentives in early and later periods. The young CEO tends to exaggerate his reactions to new information and act boldly on it in order to signal a superior ability to decipher information about the investment opportunity. The older CEO, however, is more conservative in his response to new information in order to signal that he has been in possession of precise information in the past, and that a change of course will reflect poorly on his past decisions and consequently on his abilities. In this view, a younger CEO who wants to establish a reputation for being talented is prone to taking riskier actions. We refer to 
this model as the Managerial Signaling Model. To test the predictions of these two types of models, we follow extant studies (e.g., Gibbons and Murphy (1992) and Chevalier and Ellison (1999)) and measure the extent of a manager's career concerns using his age. Given the age-related difference in incentives, we focus on whether the firm's investment decisions can be explained in part by its CEO's age.

As we employ micro-level data from the U.S. Census Bureau to carry out the analysis, we are able to characterize investments very generally to include all firm activities that increase or decrease or alter the composition of a firm's asset base, which comprises of the firm's business segments and establishments within each segment. We begin by using establishment-level information from the Longitudinal Business Database (LBD), which covers every U.S. private non-farm sector establishment, to construct a complete picture of all the plants and industry segments a firm operates in. We then construct real investment variables based on the year-to-year change in the composition of the firm's asset portfolio. This way, we can identify those substantial investment decisions, like entry and exit into new lines of business, in which the CEO is expected to play an important role. We match the LBD with COMPUSTAT to obtain accounting variables for publicly listed firms. From Compact Disclosure we extract the CEO's age, his tenure, and corporate governance variables. The matched sample leaves us with a sizeable sample of 62,414 firm-year observations (9,344 unique firms) from 1988 to 2005 with complete information on CEO age, selected accounting variables, and real investment information.

We show that CEO's age has first order effects on a firm's investment decisions. In particular, we find that younger CEOs lead a "busy life". Driven by their desire to establish their reputations, younger CEOs are more likely to alter a firm's existing asset base by both entering new business segments and simultaneously withdrawing entirely from other existing business segments. In contrast, as CEOs get older, they seem to prefer a "quiet life" by refraining from churning their firms' existing business portfolios. Other things equal, firms with CEOs under 50 years of age are 6 percentage points less likely to keep the firm's complete business profile the same as that of the previous year, compared to firms with CEOs aged 60 and above. In contrast, firms with CEOs younger than 50 are 3 percentage points more likely to enter a new business segment and 4 percentage points more 
likely to exit from an existing business segment, relative to firms with CEOs aged 60 and above. These findings are statistically significant and economically relevant, even against a backdrop of fairly dynamic ongoing restructuring among our firms. In our sample, one quarter of the firms either enter a new segment or exit from an existing segment in any given year. Therefore, relative to the unconditional probability of restructuring, a young CEO increases the probability of restructuring by $10 \%$ to $15 \%$.

Younger CEOs not only restructure more, they take on bigger and bolder projects consistent with the Managerial Signaling Model. A younger CEO is also more likely to undertake larger restructuring activity as proxied by the relative number of employees affected by the restructuring. In addition, these segment churning activities of younger CEOs are associated with faster asset and employment growth. Younger CEOs are also associated with increased investment in research and development expenditures, a type of investment that is often considered more risky. Between the two ways of initiating a plant, younger CEOs favor acquiring a plant from another firm over building a plant from scratch. We perform additional analyses to ensure that the effect of CEO age on firm restructuring activities is not due to other confounding factors. One might argue that such effects are due to the fact that younger CEOs tend to manage different types of firms from older CEOs. We address this concern in several ways. First, younger CEOs tend to be associated with smaller, single-segment firms. If smaller and single-segment firms are more likely to restructure, the relation we find may be spurious. However, our results continue to hold in sub-samples of firms of different sizes and for single- versus multi-segment firms. Second, our results are robust to controlling for firm fixed effects which control for unobservable firm characteristics. Third, the CEO age effect may simply reflect the selection of young CEOs by firms that need more restructuring. But, when we delete observations belonging to newlyhired CEOs, the results continue to hold in the remaining sample of long-tenured CEOs where the matching is less perfect. Finally, we also make use of a propensity score matching approach to ensure that our results are not driven by the nonlinear effects of certain firm characteristics on a firm's restructuring propensity. Therefore, our results are not driven by confounding firm characteristics. The relation between CEO age and investment activities may result from CEOs' other traits than career concerns. We find that the effects of age 
on investments are robust to the inclusion of CEO fixed effects and variables that proxy for CEO overconfidence and CEO compensation incentives.

Since we find that investments depend on CEO age, this raises questions about the distortive effects of career concerns in terms of firm performance. The Market Learning and Managerial Signaling models yield distinct contrasting predictions regarding the effect of career concerns on investment activities. Yet, both types of models imply that career concerns could distort the efficiency of corporate investments because CEOs' career concerns are not aligned with shareholders' best interests. However, Holmstrom (1999) shows that younger CEOs may exert more effort, as effort and talent may be substitutes in the production function. Hence, younger CEOs may actually make relatively better investment decisions. Consequently, the net difference in productive efficiency between younger and older CEOs is an empirical issue. We examine the impact of CEOs' investment activities on plant-level efficiency using detailed plant-level input and output data from the Annual Survey of Manufactures (ASM) and the Census of Manufactures (CMF). ${ }^{1}$ Using total factor productivity (TFP) and value-added per worker as metrics, we show that, on average, younger CEOs are associated with plants of equal efficiency as older CEOs. In a second test, we examine changes to a plant's productivity after an acquisition. In particular, we compare the outcomes of acquisitions made by CEOs of different ages. We do not find any evidence that younger CEOs are associated with a decrease in productivity in the post-acquisition period. Acquisitions made by younger CEOs experience at least as great an improvement as those made by older CEOs.

We further analyze the impact of career concerns on the allocation of capital in plants within a firm. To this end, we distinguish between plants that are "inherited" by the CEO, versus plants that are not. A "not-inherited" plant is either built from scratch or acquired from other firms during the current CEO's tenure. We find that managers tilt incremental capital expenditures towards plants that they themselves initiated. This type of managerial favoritism is, however, not affected by CEO career concerns as older CEOs and younger

\footnotetext{
${ }^{1}$ The plants in the ASM and CMF are a subsample of those in the LBD, The LBD contains all plants from all industries while the ASM and CMF only contains plants manufacturing products in SIC codes 2011-3999. Our result that younger CEOs engage in more restructuring continues to hold in the ASM and CMF subsample.
} 
CEOs are equally prone to such favoritism. This paper highlights the important role that a CEO's career concerns plays in shaping corporate investment policies. A younger CEO is more likely to take bolder investment actions altering a firm's existing business portfolio. An older CEO prefers to maintain the status quo, consistent with Bertrand and Mullainathan's "quiet life" view of what CEOs want. More importantly, the investment churning behavior of the young $\mathrm{CEO}$ is not necessarily efficiency-destroying relative to older CEOs. This pattern of behavior is also consistent with the claims that young people have higher energy levels (Roberts and Rosenberg, 2006), are more confident (Taylor, 1975), and are more combative due to the presence of a hormone effect (Levi, Li, and Zhang, 2010).

Our paper is part of a growing body of research that shows that there is heterogeneity in CEO characteristics, and that these differences indeed matter for corporate policies. In particular, recent empirical work has shown that CEO characteristics matter for firm investments: e.g., firm investment and acquisition decisions are affected by CEO styles (Bertrand and Schoar, 2003), CEO overconfidence (Malmendier and Tate, 2005, 2008), managerial miscalibration (Ben-David, Graham, and Harvey (2010)), and CEO age (Yim, 2010). Our paper is most closely related to Yim (2010). She finds that younger CEOs are more likely to undertake acquisitions and she argues that this is partly because of the compensation benefits derived from managing bigger firms. However, our paper shows that not only do younger CEOs make more investments, but that they also make more divestitures. Our measures of investment activities are also more comprehensive as we examine not only acquisitions of whole firms, but more generally any activities that affect a firm's asset base. Finally, because of the use of detailed plant-level data, we are also able to examine how CEO age affects the productivity of plants acquired by young and old CEOs.

The rest of the paper is structured as follows: In section 4.2, we review the theoretical and empirical literature on how career concerns distort the behavior of decision makers and propose several testable hypotheses. We describe our data and key variables in section 4.3. We conduct the empirical analysis in section 4.4. Section 4.5 concludes. 


\subsection{Literature review and hypotheses development}

Fama (1980) is the seminal work advancing the notion that career concerns can influence corporate performance. He argues that managers are disciplined by an efficient managerial labor market where poor performance by a manager will prompt the market to revise its beliefs about the manager's ability. Poor performance can thus lead to lower future wages and early dismissal; this disciplinary effect helps curb managerial agency problems. However, Holmstrom (1999) points out that there are circumstances where reputation effects cannot overcome agency problems. In his model, Holmstrom analyzes the nature of career concerns where the market is learning about the ability of the manager based on previous performance. Therefore, investment decisions and their subsequent performance provide information on managerial talent and ability. Perceptions about talent not only affect future wages but also affect whether the manager is fired or not. Therefore, from the manager's perspective, investment decisions can become especially risky. In a related learning model, Holmstrom and Ricart i Costa (1986) show that risk-averse managers are generally less likely to undertake new investment projects since performance about the new project will reveal information about the manager's ability. Our Market Learning Hypothesis implies that younger CEOs are more likely to act conservatively.

Alternatively, younger CEOs are more willing to undertake new projects as signals of their ability to the executive labor market. Prendergast and Stole (1996) examine the investment incentives of a manager over his career life cycle. They stress that young managers are more prone to taking bolder actions to signal that they have more precise information.

In their model, talent is related to the ability to receive precise signals; therefore, a young manager who wants to establish a reputation for being talented is prone to taking risky actions. Older managers, in contrast, shy away from changing the course of action frequently, because such changes might reveal that their previous decisions were wrong. Similarly, Bebchuk and Stole (1993) point out that a manager's concern for his short-term reputation can lead to distortions in the investment behavior of the firm. They argue that when the investment is visible, a manager will over-invest to signal the ability to generate good growth opportunities. We refer to this argument as the Managerial Signaling Hypothesis. 
In this paper, we examine plant-level activities to investigate the effects of career concerns on corporate investment behavior. A study of plant-level activities provides a proper experiment to test the effects of career concerns on firm investment activities because we are able to construct a complete picture of a firm's investment activities at this level: 1) firms can increase their asset base in an existing industry they are already operating in by increasing capital expenditures or buying assets from another company; 2) firms can enter into a new industry segment either through greenfield investments or through taking over another firm or buying assets from another firm; 3) firms can decrease their asset base by selling some of their assets; and 4) firms can stop operations in an industry segment altogether. As Maksimovic and Phillips (2001) point out, the merger market accounts for only half of the assets being traded, with partial-firm asset transactions accounting for the rest. Thus, by using plant-level information, we are able to differentiate and also capture the full range of investment activities firm engages in.

Our null hypothesis is that managerial career concerns do not affect plant buying and selling, plant creation and shut down, or incremental investment. We state the null hypothesis in H1: H1: The restructuring activities of a firm are not related to the age

\section{of its CEO.}

The Market Learning Hypothesis predicts that young CEOs, relative to older ones, are less likely to make changes to their firm's portfolio of plants through restructuring activities, as stated in H1a below.

\section{H1a: Younger CEOs are less likely to engage in restructuring activities.}

In contrast, the Managerial Signaling Hypothesis predicts that younger CEOs are more likely to alter their firms' portfolio of plants through restructuring in order to signal their ability, as stated in H1b.

\section{H1b: Younger CEOs are more likely to engage in restructuring activities.}

Based on prior literature, it is unclear which of the above alternative hypotheses will be supported by data. Prior evidence from different job contexts supports the Market Learning Hypothesis (see e.g., Chevalier and Ellison (1999) for mutual fund managers, Hong, Kubik, and Solomon (2000) for security analysts, and Lamont (2002) for macroeconomists). 
However, other prior research is suggestive of the relevance of the Managerial Signaling Hypothesis for CEOs. Relative to other labor markets, arguably younger CEOs may prefer bolder decisions based on the incentives they face. Managers trade off the benefits from signaling superior ability, which leads to an increase in pay and career advancements, against the potential disadvantage, which is losing one's job. If the disadvantage is greater, then as the Market Learning Hypothesis predicts that the manager will desist from risky bold actions. However, the likelihood of job loss seems to be low for CEOs based on prior work, though most of this work does not differentiate between young versus old CEOs, compared to terminations for mutual fund managers, security analysts, or macroeconomists. Based on Huson, Parrino, and Starks (2001), Taylor (2010), and Kaplan and Minton (2010), the forced termination rate for CEOs at large U.S. corporations is on average a mere $2 \%$. According to Weisbach (1988, Table 2, p. 439), after accounting for retirements, deaths, and illnesses, the rate of terminations was 3.32\% for CEOs of NYSE firms over 1974-1983. In Jenter and Kanaan (2010, Table 1), the rate of forced turnover is $2.3 \%$. When differentiated according to CEO age, Yim (2010) finds that younger CEOs are not more likely to be fired for poorly performing acquisitions. In contrast, Hong, Kubik, and Solomon (2000, Table 2, p. 130) find the separation rate is $15.83 \%$ for security analysts on average, and $22 \%$ for the young and bold analysts, over ten years, 1986-1995. In Chevalier and Ellison (1999, Table II, p. 398 ), out of the 242 cases of separation for mutual fund managers over the years, 19921994 , taking account of potential retirements and promotions, the separation rate is $15.2 \%$. Furthermore, younger CEOs have powerful financial incentives to signal superior ability since it can translate into substantial extra compensation over their remaining careers. According to Gudell (2010), the median compensation for the first appointment as CEO is $\$ 2.6$ million (in 2000 dollars). The figure jumps to $\$ 4.7$ million for the second CEO job, and then to $\$ 8.2$ million. This crude costs and benefits comparison is suggestive of CEO incentives consistent with the Managerial Signaling Hypothesis.

Any restructuring activities, induced by CEO's career concerns, might not be efficiencyimproving. For instance, Narayanan (1985) shows that a manager hoping to enhance his reputation earlier will tend to make decisions that yield short-term gains at the expense of the long-term interests of the shareholders. Scharfstein and Stein (1990) find that career 
concerns lead managers to herding behavior in investments. Furthermore, reputational concerns may lead managers to hang on to underperforming projects, causing an escalation of commitment problem (Boot (1992)). However, Holmstrom (1999) argues that since effort and ability are substitutes, a young manager over-invests in labor to influence the market's perception of his ability whereas an older manager has already established a reputation based on past performance and is therefore no longer as concerned about improving reputation. Thus, younger managers may exert more effort when making investment decisions, leading to potentially more efficient decisions. Therefore, the predicted net effects of career concerns on efficiency are unclear, leading to our second hypothesis in the null form.

\section{H2: Efficiency of restructuring activities is not affected by a CEO's career} concerns.

It is likely that CEO career concerns not only have an impact on project initiation but also on subsequent project decisions. An implication of the signaling model of Prendergast and Stole (1996) is that managers may suffer from a so-called "trapped administrator" effect, first pointed out by Fox and Staw (1979). Managers who have established an unprofitable plant or acquired a bad plant suffer from an escalation of commitment problem, and may be reluctant to admit their mistakes and reverse their decisions. The admission of a mistake may indicate that their initial decision was bad and may taint their reputation (Boot, 1992). Weisbach (1995) provides some evidence consistent with such an escalation of commitment argument. ${ }^{2}$ He finds that at the time of a change in management, there is an increased probability of divestment of poorly performing acquisitions. Thus, a manager may be more reluctant to cease investing in failing plants if he was the one who initiated the creation of that particular plant, compared to plants inherited from predecessors. In addition, managers may channel excessive capital expenditures to plants they have initiated in order to stave off failure. ${ }^{3}$ To the extent that younger CEOs have greater career concerns, they may be particularly prone to divert extra capital to projects that they have initiated to ensure a favorable outcome. Therefore, our third hypothesis is as follows:

\footnotetext{
${ }^{2}$ Jin and Scherbina (2010) document similar behavior of hanging on to losers for mutual fund managers.

${ }^{3}$ Similarly, Goel, Nanda, and Narayanan (2004) propose that career concerns can distort allocations within internal capital markets.
} 


\section{H3: A CEO with greater career concerns will channel excessive capital to} projects he initiated, even if the project is not doing well.

\subsection{Data}

In this section, we discuss the formation of our sample, sources of data, and methodology to test the above hypotheses. We first describe how we classify the various plant-level activities using data from the U.S. Census Bureau.

\subsubsection{Classification of plant-level activities}

The LBD is a longitudinal database of all business establishments in the U.S. private non-farm economy that file payroll taxes with the IRS. ${ }^{4}$ It is constructed from the Census Bureau's Business Register and enhanced with various survey data. As such, the LBD covers the universe of establishments in the U.S. non-farm business sector with at least one paid employee. It currently spans the years 1976 to 2005 (as of the time we conducted the analysis for this paper). In recent years, it contains over 6 million establishment records and almost 5 million firm records every year. An establishment is a specific physical location (e.g., a factory, store, and/or office) where business takes place. We refer to establishments and plants interchangeably throughout the paper. The LBD contains information on plant births, plant deaths, and plant acquisitions and divestures, which allow us to track the history of each plant. For each plant, we can therefore determine when it is built, and when it first becomes a part of a firm's portfolio. Importantly, the LBD is not restricted to plants in the manufacturing sector. ${ }^{5}$ This allows us to construct a more complete picture of a firm's restructuring activities across different industries. One drawback of the LBD is that it contains only some basic data, i.e., ownership, employment, payroll, four-digit Standard Industrial Classification (SIC), and first/last year of operation. Therefore, in some tests, we also rely on the ASM and CMF for detailed data on plant productivity. We have checked

\footnotetext{
${ }^{4}$ See Jarmin and Miranda (2002) for a detailed description of the LBD.

${ }^{5}$ Previous studies mostly use data from Longitudinal Research Database (LRD) to examine plant investment activities. See, e.g. Maksimovic and Phillips (2001, 2008). The LRD covers only plants in the manufacturing sector which is declining in importance in the U.S. economy. For instance, retail and whole trade, restaurants and hotel, banking, and business service industries combined account for over $70 \%$ of all the establishments in the LBD.
} 
that our main results work both on the broader LBD sample as well as the subsample of manufacturing firms in the ASM and CMF.

There are several advantages to using the Census Bureau databases relative to COMPUSTAT when examining firm investment behavior. Publicly available data such as COMPUSTAT only provide firm level aggregate capital expenditures. This does not allow us to capture the frequency of new projects being initiated since the capital expenditures can just go towards upgrading existing plants, properties and equipment. Furthermore, we cannot determine the characteristics and profitability of the projects where these capital expenditures have been put to use. The Census Bureau data allow us to differentiate between incremental investments and large changes to a firm's asset portfolio. Furthermore, since data are at the plant level, we can track the performance of plants over time, and especially after an acquisition.

We characterize investments mainly at the segment level where a segment is defined based on a collection of plants with the same three-digit SIC industry codes. ${ }^{6}$ Establishmentlevel data are aggregated up to segments for each firm which gives us a portfolio of segments in which a firm operates (owns at least one establishment). We follow the number of establishments within each segment over the years. Investment activities are characterized by comparing current year's segment profile with last year's segment profile. We classify investments into five categories according to both the changes to segments as well as changes within a segment. In particular, we construct the following five indicator variables:

(1) Entry into a new segment (ENTRY). The indicator variable, ENTRY, is equal to one if at least one of the firm's current year segments was not present in the firm's portfolio last year, i.e., a firm just entered into a new segment. A firm's entry into a new segment can be a result of an acquisition of an establishment or building of a de novo establishment in a new segment.

(2) Exit from a segment (EXIT). The indicator variable, EXIT, is equal to one if at

\footnotetext{
${ }^{6}$ The Census Bureau adopted the North America Industry Classification System (NAICS) in 1997 but maintained SIC codes on its business register until 2001. After 2001, we converted NAICS codes to SIC codes using a concordance table between SIC and NAICS provided by the Census Bureau. As segments births and deaths are characterized by comparing adjacent years, we check that our results do not change when we delete the years 2002 and 2003 since these years are most likely to be affected by the change in industry classification codes.
} 
least one of last year's segments no long exists in the firm's portfolio in the current year. A firm's exit from a segment can be a result of the sale or closure of all the establishments in the segment.

(3) Increase investment in an existing segment (INCREASE). The indicator variable, INCREASE, is equal to one if the firm increases the number of establishments in at least one of the existing segments relative to last year. This could include creation of de novo establishment(s) or acquisition of establishment(s) in a segment in which the firm is already operating.

(4) Divestment from an existing segment (DECREASE). The indicator variable, DECREASE, is equal to one if the firm reduces the number of establishments in at least one of the existing segments compared with the previous year. This will include both the shut down and the divestiture of establishments in a segment in which the firm is already operating.

(5) No change in existing segments (NOCHANGE). The indicator variable, NOCHANGE, is equal to one if all of the above four variables take the value of zero, i.e., a firm's current year's portfolio is exactly the same as in the previous year.

We use an example to illustrate the above categorizations. Suppose that a firm owns 2 establishments in segment A, 3 establishments in segment B, and 4 establishments in segment $\mathrm{C}$ in year 2000. In year 2001, this firm owns 3 establishments in segment A, 2 establishments in segment B, and 1 establishment in segment D. In this case, in 2001, this firm has a ENTRY=1 because it ventures into a new segment - segment D. EXIT=1 because it sheds all of its establishments in segment C. INCREASE=1 because it increases the number of establishments in segment A from 2 to 3 , and DECREASE $=1$ because it reduces the number of establishments in segment B from 3 to 2. As a result, NOCHANGE is equal to 0 in 2001. As one can see from the above example, it is entirely possible for a firm to have any combination of values among ENTRY, EXIT, INCREASE, and DECREASE, but NOCHANGE should be mutually exclusive relative to the former four activities.

We characterize investment in this manner to ensure that the investment decisions are substantial ones, in which the CEO would be expected to have a role in the decisionmaking process. In particular, we would expect changes in the industry segments that the 
firm operates in, i.e., ENTRY and EXIT, to be primarily decided by the CEO. In Figure 1, we plot the yearly percentages of firms in our sample entering into a new segment, exiting from a segment, and firms with no change to their segment portfolios. In a typical year, on average, $40 \%$ of the firms keep the status quo relative to previous year (NOCHANGE), about one quarter of firms either enter a new segment (ENTRY) or exit an existing segment (EXIT). Restructuring activities are spread out across the years, although there is a slight trend towards less restructuring in the more recent years.

\subsubsection{Plant productivity and capital expenditures}

Despite the comprehensive coverage and information on restructuring activities, the LBD covers limited data items. For detailed plant-level information on inputs and outputs, we turn to the ASM and CMF databases, which are also maintained by the Census Bureau. These two databases include information on the total value of shipments, expenditures on intermediate and primary inputs, and other input and output measures needed for performance analysis. These data are collected during the economic census, which takes place in years ending in 2 and 7, and covers approximately 350,000 manufacturing plants each time. The ASM typically samples about 60,000 plants in non-census years. All plants with more than 250 employees and all plants that are part of very large firms are included by design. Some 40,000 other plants are selected with a probability proportional to a composite measure of their size. Once a plant is surveyed, ASM continues surveying this plant to form a 5-year panel.

From the ASM and CMF, we construct two proxies of productivity to measure the performance of a plant. Our first measure of productivity is total factor productivity (TFP). Using all plants in the ASM and CMF databases, we follow Bertrand and Mullainathan (2003) and estimate the below equation separately for each industry and for each year:

$$
\log \left(\text { Output }_{i}\right)=\alpha+\beta_{1} \log \left(\text { Wagebill }_{i}\right)+\beta_{2} \log \left(\text { Capital }_{i}\right)+\beta_{3} \log \left(\text { Material }_{i}\right)+\epsilon_{i}
$$

where i indexes plants; Output is measured by the total value of shipments; Capital is 
the value of the capital stock; Wagebill is the total amount of salaries and wages; Material is the cost of materials, parts, intermediate goods, energy and electricity. ASM no longer reports capital stock after 1988 and we compute capital stock using a perpetual inventory method. In particular, we begin with a plant's previous census year's capital stock, adding up reported capital expenditures year by year, and adjusted using the industry-wide investment deflators in the NBER-CES Productivity Database. ${ }^{7}$ TFP takes the actual amount of output a plant produces with a given amount of inputs and compares it to a predicted amount of output. The predicted output is what the plant is expected to produce given the amount of inputs it uses. The residual from the above estimation is used as the TFP measure. Since coefficients on capital, labor, and material inputs vary by industry and year, this specification allows for different factor intensities in different industries. The residual can be interpreted as the efficiency measure of a plant relative to other plants in that same industry in a given year.

Because the estimation of the TFP requires a particular functional form, we also check the robustness of our results by using the logarithmic transformation of value-added per worker where value-added is total output less intermediate inputs and cost of materials. This measure is better suited to capture the labor productivity of the plant.

\subsubsection{Firm financial variables and CEO age}

The firm-level accounting information is obtained from COMPUSTAT. ${ }^{8}$ Following prior literature on the determinants of investment policy, we use a set of variables that include firm size (measured by total book value of assets), firm performance (measured by stock returns and return on assets), cash (measured by ratio of cash to total assets), and firm's growth prospects (measured by Tobin's Q). The Appendix lists detailed definitions of these variables. CEO personal characteristics are obtained from Compact Disclosure Compact Discs, which collects information from firms' various financial reports. The first year in Compact Disclosure goes back to 1988. We extract two variables from it: CEO age and tenure. We count tenure as the number of years since the first time the person became

\footnotetext{
${ }^{7}$ Available at http://www.nber.org/nberces/.

${ }^{8}$ Linkage between COMPUSTAT and the LBD, ASM, and CMF is performed using the COMPUSTATStandard Statistical Establishment List (COMPUSTAT-SSEL) Bridge File maintained at the Census Bureau.
} 
the CEO of the firm according to Compact Disclosure. This creates a bias for CEOs who started prior to 1988, which happens to be the first year for our Compact Disclosure data set. To alleviate this concern, for all regressions which control for CEO tenure, we also perform the analysis on the sample in which we can determine exactly the CEO's tenure. The untabulated results show that our conclusions remain unaffected.

The main sample consists of all firm-year observations in the intersection of the LBD, COMPUSTAT, and Compact Disclosure databases. The matched sample contains 62,414 firm-year observations with non-missing information on all the accounting, and investment variables, as well as CEO age and tenure. The sample covers the period of 1988 to 2005. This matched sample forms the core of our analysis.

\subsubsection{Summary statistics}

Table 4.1 presents the means and standard deviations for our key variables. We show statistics for all firms and also separately for firms which restructure and those that do not restructure. For the sample of all firms, on average, in a given year, $42 \%$ of firms do not engage in any restructuring activities (NOCHANGE $=0.42$ ). About $25 \%$ of firms enter a new business segment $(\mathrm{ENTRY}=0.25)$. A similar proportion of firms ceases operations entirely in some segment $(\mathrm{EXIT}=0.24)$. Some $33 \%$ of the firms increase the number of establishments within at least one of their existing segments (INCREASE=0.33), whereas $29 \%$ of firms reduces the number of establishments in an existing segment (DECREASE=0.29).

In our sample of all firms, the average age of a CEO is about 53.6 years old, and $46 \%$ of the CEOs have tenure of less than 3 years. Note, however, that CEO tenure is downward biased since we start counting tenure from the first year the CEO enters our database. When we restrict our CEOs to those for whom we can determine the tenure exactly, we also find that $46 \%$ of the CEOs have less than 3 years of tenure. The average firm owns some 64 establishments, and those establishments operate across 4 industry segments. In untabulated results, the average firm in the ASM/CMF has only 14 plants and operates across 2 industry segments. This is expected since the ASM/CMF only contains manufacturing plants operating in SIC codes 2011-3999. In Panel B, each manufacturing establishment employs about 343 employees and is about 17 years old. 
In the second and third columns, we separate the firm-years based on whether they have any restructuring activities for the year and report the means and standard deviations for the two subsamples of firms. We also perform T-tests to compare the differences across the two subsamples. Conditional upon restructuring, $43 \%$ of the firms enter into a new segment, $42 \%$ exit from an existing segment, $58 \%$ increase the establishments of at least one of their segments, and $51 \%$ decrease the number of establishments in at least one of their segments.

Consistent with the Managerial Signaling Hypothesis, firms that change their asset base profiles are managed by CEOs about 1.2 years younger, compared with firms that maintain the status quo. This difference in age is significant at the $1 \%$ level. This preliminary analysis suggests that younger CEOs are more likely to lead a busy life by engaging in investment activities. In contrast, CEOs who prefer a quiet life are older. However, the two types of firms also differ significantly in other dimensions. Firms engaging in restructuring are significantly larger and have better operating performance. In addition, firms that do not restructure have higher growth prospects, higher stock returns and higher cash ratio. These observations highlight the importance of controlling for firm size and performance measures, among other variables, when analyzing the investment activities. In the next section, we conduct multivariate regression analyses. Manufacturing plants operated by firms which restructure employ marginally less employees and have lower levels of capital expenditures relative to their capital stock. Using TFP as a measure of plant productivity, plants belonging to firms which keep the status quo have lower productivity although the alternative measure of productivity, value-added per employee, indicates otherwise.

\subsection{Empirical analysis}

The Market Learning and Managerial Signaling Hypotheses described in Section 4.2 predict that managerial career concerns have an impact on firm investment activities. In this section, we first analyze how CEO career concerns affect the likelihood that a firm will undertake restructuring activities. Then, conditional upon having undertaken a restructuring activity, we examine the characteristics of the investment. After establishing a relation 
between firm investment and CEO age, we next examine the performance consequences of such career concerns.

\subsubsection{CEO age and investment}

Following the literature on career concerns, we proxy for the degree of career concerns faced by a CEO with his age. Logistic regressions are used to analyze the likelihood of each type of investment activity:

$$
\operatorname{Prob}\left(I_{i t}\right)=\alpha+\beta_{1} \mathrm{Age}_{i t}+\beta_{2} \text { Tenure }+X \gamma+\text { Industry } / \text { Year FE }+\epsilon_{i t}
$$

In the above equation, I = ENTRY, EXIT, INCREASE, DECREASE, and NOCHANGE for each firm i in year t, $\mathrm{X}$ is a vector of firm i's characteristics. Age is the value of CEO's age. In other specifications, we also use three dummy variables to indicate whether the CEO is within the age intervals, under 50, between 50 and 59, and 60 years old and above, to capture the potential nonlinear effect of age. Tenure $\leq 3$ is a dummy variable equal to one during the first three years of the CEO tenure with the firm. Tenure not only controls for CEO skill but can also control for entrenchment effects. CEOs with longer tenure may be difficult to dismiss and thus have reduced career concerns. Firm level controls also include the number of establishments and the number of segments owned by the firm. All these regressors are lagged one year to avoid obvious endogeneity concerns. We also control for year and industry fixed effects. It is important to control for industry fixed effects as it is possible that young CEOs are risk-loving and are attracted to risky industries. To the extent that risky industries restructure more because of the nature of their business, a positive association between CEO age and restructuring activities could arise not because of career concerns but because of spurious correlations.

Baseline results on the relation between CEO age and investment activities are reported in Table 4.2. In this cross-sectional analysis, age is positively associated with NOCHANGE, but negatively associated with the remaining four investment variables. It is also statistically significant at the $1 \%$ level for NOCHANGE, ENTRY, EXIT, and INCREASE. This indicates that younger CEOs are more likely to enter a new segment, as well as cease oper- 
ations in an existing segment. In contrast, older CEOs prefer to maintain the status quo. We do not find any effect of CEO age on decreases (DECREASE) in number of plants within a segment. This is understandable as such restructuring activities may fall more in the domain of divisional managers rather than that of the CEO.

The last row reports the marginal effect of a one-year increase in age associated with the percent change in the probability of each investment outcomes. A firm with a CEO ten years younger is about $1 \%$ and $2 \%$ more likely to enter into a new line of business and exit from an existing segment, respectively. It is also $1 \%$ more likely to increase as well as to reduce the number of establishments in at least one existing segment. CEOs who are ten years older are 3 percent more likely to maintain the status quo in each given year. Relative to the unconditional probability of retaining status quo (42\%), for CEOs who are older by 10 years the probability of no restructuring activities increases by $7 \%$. These findings offer support for the Managerial Signaling Hypothesis, according to which younger CEOs are more likely to lead a busy life altering the firm's existing business profile.

Note that the observed relation between CEO age and restructuring activities cannot be attributed to the fact that younger CEOs are likely to be new CEOs and restructuring is more likely to take place following a turnover (Weisbach, 1995). We find that during the first three years of the CEO's tenure, a firm is more likely to both withdraw either partially or entirely from an existing segment. This result implies that a CEO tends to reverse the past course of action when he first takes control of the firm. In contrast, new CEOs are not eager to enter into new segments, and they also are less likely to increase the number of plants within existing segments. In unreported results we also include an interaction term between Tenure?3 and CEO age. This interaction term is not statistically different from zero, and the coefficient on age remains significant with the same sign, further reassuring us that the results are not driven by new CEOs in the sample.

The results on other determinants of investment activities are generally consistent with our expectations. A larger firm is more likely to engage in restructuring, although it is less likely to exit altogether from its current segments. Firms with more segments and more establishments tend to restructure more actively, although firms with more plants are less likely to exit from a segment totally. When a firm has better investment prospects, as 
proxied by Tobin's Q, it scales up its investment in expansions. A better performing firm (better ROA and Stock Returns) is more likely to enter new business, and to increase the number of establishments in its existing segments; better performing firms are also less likely to downsize. A somewhat counterintuitive result is that a more cash-rich firm is associated with less expansionary activities. This could be because firms pile up cash in order to take advantage of future opportunities down the road.

The estimations in Table 4.2 assume that CEO age has a linear effect on investment activities. We remove this restriction and use two dummy variables for age cohorts: age under 50, and between 50 and 59. Table 4.3 reports the regression results using these two dummy variables, where the third category - age 60 and above - is used as the benchmark. Therefore, the coefficients on each of the dummy variables can be interpreted as the difference in investment activity relative to the oldest group of CEOs.

Relative to CEOs aged 60 and above, younger CEOs are more likely to restructure the firm's existing business segments, with the coefficients on the dummy variable for CEOs under 50 larger in absolute terms. In the bottom of Table 4.3, we report the p-value from a test for the equality of the two coefficients on the two dummy variables for age cohorts. Consistent with results in Table 2, of the two relatively younger CEO cohorts, firms having CEOs under age 50 tend to have significantly more business investment activities as indicated by the p-value. In terms of the marginal effects of these age cohort variables, we find that firms with CEOs younger than 50 are 5.9 percentage points less likely to maintain the status quo, 2.6 percentage points more likely to enter a new business segment, 3.7 percentage points more likely to withdraw from an existing business segment, and 3.7 percentage points more likely to increase the number of establishments in a segment than firms with CEOs aged 60 and above. Relative to the unconditional mean for ENTRY (25\%), a $\mathrm{CEO}$ who is in the youngest age cohort increases the likelihood of entering a new industry segment by $10 \%$ relative to the CEOs aged 60 and above. The unconditional probability of EXIT is $24 \%$, therefore, compared to the oldest group of CEOs, a CEO in the youngest cohort increases the likelihood of exiting from an existing segment by $15 \%$. In contrast, the youngest group of CEOs decreases the probability of remaining status quo by $14 \%$, relative to the unconditional probability of $42 \%$ (NOCHANGE $=1$ ). 
The effects for the age group 50 to 59 are slightly smaller economically. For example, compared to the oldest group of CEOs, CEOs who are aged 50 to 59 are 2.9 percentage points less likely to maintain the status quo, 1.1 percentage points more likely to enter into a new segment, and 1.5 percentage points more likely to exit from an existing segment and increase the number of establishments in an existing segment. Results from Table 4.3 reinforce the conclusion that there is an inverse relation between CEO age and restructuring activities. As CEOs get older, they prefer the quiet life, while younger CEOs, perhaps concerned with their career prospects, are more likely to keep a busy life restructuring the firms they manage.

\subsubsection{Alternative hypotheses and robustness checks}

We conduct a variety of checks to ensure that this age effect is not a result of other confounding firm characteristics. One might argue that such effects are due to the fact that younger CEOs tend to manage different types of firms from older CEOs. We address this concern in several ways. First, it is often the case that younger CEOs manage smaller, single-segment firms. If small, single-segment firms are more likely to restructure then our results could be spurious. Therefore, we carry out the same analysis within various different sub-samples. In one test, we distinguish between single-segment firms from multi-segment firms. In another test, we create three sub-samples based on the firm's total assets to check whether the results are driven by only the small firms or the big firms. The results found in these tests closely resemble those for the baseline results in Table 4.2. For brevity of space, we do not report the results here.

Second, an alternative explanation might be that the age effect reflects the selection of young CEOs by firms that need more restructuring. If such firms happen to hire young CEOs, the above results then are due to the firm's unobservable traits, not necessarily due to the CEO's age. To the extent that a firm's restructuring propensity is an ongoing trait, we alleviate this concern by controlling for firm fixed effects. Table 4.4 reports the related results using a linear probability model. ${ }^{9}$ Basic findings on NOCHANGE, ENTRY, EXIT,

\footnotetext{
${ }^{9}$ We opt for linear probability model due to the presence of a large number of fixed effects which would lead to the incidental parameters problem (see e.g., Wooldridge (2002, pp. 484)).
} 
and INCREASE continue to hold as in Table 4.2. The interpretation is slightly different, though. "Within" a firm, when the CEO is older, the firm becomes increasingly likely to maintain the status quo, and refrains from either entering into new segments or withdrawing from an existing segment. The economic effects are very similar to the ones in Table 4.2.

Third, we conduct a propensity score regression analysis to alleviate the concern that the age results are driven by differences in observable characteristics of firms that have young versus old CEOs (Hirano, Imbens, and Ridder, 2003). We follow Yim (2010) and first run a logit model where the dependent variable is "CEO age $\leq 50$ " on firm-level variables that also include firm's age which measures the stage in the life-cycle of the firm. As column (1) of Table 4.5 shows, younger CEOs are more likely to serve on younger firms with fewer segments and plants. In columns (2) to (6), we re-weight the observations with the inverse of propensity score, which is defined as the predicted probability of having a young CEO according to the results in column (1). ${ }^{10}$ The weighted OLS results confirm that younger CEOs are more likely to engage in restructuring activities. This empirical exercise further affirms that the age result is not driven by distributional differences in observed covariates between firms with old versus young CEOs.

Last, to address an inherent selection bias, we delete the newly-hired CEOs. The intuition is that at the time of the hire the CEO and the firm are most well matched, both having just voluntarily come together. The longer the CEO stays with the firm, the more likely it is that the firm's needs could deviate, so that matching between the CEO and the firm's needs may become less perfect. Yet, when we restrict the analysis to CEOs who have been in the position for at least five years, the results remain similar. This robustness check also shows that our results are not driven by the fact that young CEOs tend to be new hires and newly-hired CEOs tend to make more investment and do more restructuring. To sum up, a battery of tests shows that other firm characteristics are not driving the relation between $\mathrm{CEO}$ age and firm investment activities. Next, we examine whether CEO age is proxying for other CEO traits rather than CEO career concerns.

\footnotetext{
${ }^{10}$ Treated and control observations are weighted by $1 / \mathrm{p}(\mathrm{X})$ and $1 /(1-\mathrm{p}(\mathrm{X}))$, respectively, in the regressions. $\mathrm{P}(\mathrm{X})$ is the predicted probability of being treated, i.e. having a CEO under age 50. We follow Imbens and Wooldridge $(2007)$ by trimming observations with $\mathrm{p}(\mathrm{X})$ outside of the interval $[0.1,0.9]$ to eliminate poor candidates for matching across the control and treatment samples.
} 
Younger CEOs may become overconfident about their abilities because they were able to climb up to the top of the corporate ladder at a young age. Malmendier and Tate (2008) show that overconfident CEOs are more likely to undertake acquisitions. To take into account CEO overconfidence and other CEO personal characteristics that may be driving our results, we repeat our analysis after controlling for CEO fixed effects in Table 4.6. The purpose of running CEO fixed effects regressions is to remove any unobserved time-invariant CEO's personal characteristics that may affect firm investment decisions. Since we include CEO fixed effects and age at the same time, we exclude the year fixed effects to reduce issues of multicollinearity. The results closely resemble those in Table 4.2. The results imply that, "within" CEOs, as they grow older, they are less likely to engage in investment activities by changing the profile of a firm's segment. This also constitutes a more direct test of Prendergast and Stole (1996), who argue that CEOs are more reluctant to reverse past decisions as this would imply that they were wrong in the first place. In another direct test, we include the options-based measure of overconfidence used in Hirshleifer, Low, and Teoh (2010) as an additional control variable. This has the advantage that, if younger CEOs are more infected with overconfidence, we control for it directly. Although the sample is substantially reduced, our main results between CEO age and restructuring activities remain.

Gibbons and Murphy (1992) argue that older CEOs have less career concerns and that their explicit compensation contract would take into account this. They find evidence in support of their model that older CEOs have higher pay-performance sensitivity in their compensation contracts. Sundaram and Yermack (2007) show that older CEOs have more debt-like pension as compared to younger CEOs whose compensation are more equity-based. This may change the risk-aversion of older CEOs making them more likely to prefer the quiet life. In untabulated results, we control for CEO pay-performance sensitivity. In particular, we calculate the delta values of a CEO's portfolio of own-firm stock and stock options using the "one-year approximation" method outlined in Core and Guay (2002). Delta is defined as the dollar change in a CEO's stock and option portfolio for a $1 \%$ change in stock price. Although the sample is much reduced to those firms found in Execucomp, our results are robust to controlling for $\mathrm{CEO}$ delta. This robustness check also highlights the fact that 
CEO compensation contracts may not completely overcome the effects of career concerns on investments.

In untabulated results, we also examine whether the relation between $\mathrm{CEO}$ age and various restructuring activities are driven by differential corporate governance in firms managed by young CEOs versus old CEOs. We control for various corporate governance variables, e.g., board size, proportion of insider directors, an indicator variable for whether the CEO is also the chairman of the board, and also the governance index proposed by Gompers, Ishii, and Metrick (2003). Results are robust to the inclusion of these governance variables. That is, the effects of career concerns on investment decisions are not undone by these governance structures.

\subsubsection{Characteristics of investment activities}

So far, we have found that younger CEOs are more likely to change the firm's asset base, consistent with the Managerial Signaling Hypothesis. We emphasize the likelihood of various types of restructuring activity, such as entries and exits from lines of business or plant births and deaths. In this section, we approach the Managerial Signaling Hypothesis in a different manner, examining now the size and mode of these restructuring activities. If younger managers are indeed trying to signal their abilities, as the Managerial Signaling Hypothesis suggests, then they are also more likely to take on bolder, riskier, and more visible activities.

We first look at the size of the investment. Since our main analysis uses indicator variables, it does not allow us to capture the significance of these investment activities. To overcome this shortcoming, we use changes in employment to measure the magnitude of the investment activities. Our earlier analysis shows that young CEOs are both more likely to enter a new segment and withdraw from an existing segment at the same time. We construct two related variables: Employment (Entry) and Employment (Exit) which measure the share of employment attributable to the segments a firm enters and withdraws from, respectively. The employment numbers are aggregated across all the new segments if the firm enters more than one segment, and are similarly aggregated across all the exiting segments. The regressions are at the firm-year level. When examining Employment 
(Entry), we restrict the sample to firms which enter into at least one new segment and when examining Employment (Exit), firms are required to have exited from at least one existing segment. The results are shown in columns 1 to 4 in Table 4.7. We show results using $\mathrm{CEO}$ age and also the $\mathrm{CEO}$ age cohorts. The results confirm that the segment-level investment activities that we used earlier also correspond to sizeable changes in terms of employment. Holding other things constant, firms managed by CEOs under the age of 50 enter into new segments which increase employment by 3.3 percentage points relative to CEOs aged 60 and above. CEOs between age 50 and 59 also are more likely to enter into segments with a bigger impact on employment than the oldest category of CEOs. When exiting from segments, younger CEOs are also more likely to exit from bigger segments. CEOs aged 50 and below exit from segments affecting 2.2 percentage points more of the employees, relative to the oldest group of CEOs.

One question that arises would be the overall impact on employment since we find that young CEOs enter into and exit from segments that affect more employees. We estimate the effect of CEO age on the firm's employment growth, measured by the difference between the firm's current year number of employees and previous year's divided by its previous year's number of employees. We obtain overall employment figures from COMPUSTAT. We find that, as shown in columns 5 and 6 of Table 4.7, younger CEOs are associated with a faster growth rate in the firm's employment. Other things equal, firms managed by CEOs under the age of 50 grow by nearly 6 percentage points faster than firms with CEOs aged 60 and above. CEOs aged between 50 and 59 grow their firms by about 2 percentage points faster than the oldest group of CEOs. In untabulated results, we find that young CEOs are associated with faster asset growth as well.

We now turn to two commonly-used measures of firms' investments: Capital expenditures and R\&D expenditures from COMPUSTAT. As shown in the first two columns in Table 4.8, younger CEOs spend more resources on property, plant, and equipment. Other things equal, relative to CEOs aged 60 and above, a CEO younger than 50 years old is associated with 0.76 percentage points higher capital expenditures. R\&D expenditures typically are viewed as high-risk investments compared to capital expenditures on property, plant, and equipment (e.g., Coles, Daniel, and Naveen, 2006). In columns 3 and 4, we run 
regressions of R\&D scaled by book assets on CEO age. We find that younger CEOs invest in more R\&D than older CEOs, consistent with younger CEOs taking on riskier investments to signal their abilities. On average, a CEO younger than 50 spends about half of a percentage point more on R\&D than CEOs 60 and above.

Another way to measure the boldness of the investment is to look at the way a CEO invests in new projects. A CEO can initiate a new project by either building a de novo plant or by acquiring a plant from another firm. Arguably, acquisitions can have an instantaneous, though more uncertain, impact on a firm's performance. On the other hand, building from scratch might take longer to affect performance, and hence not be observed by the market until later. The Market Learning Models suggest that CEOs with career concerns are more likely to build plants from scratch. In contrast, the Managerial Signaling Model suggests that CEOs with career concerns prefer acquisitions.

Within the sample of plants initiated by the CEO, we differentiate between plants built from scratch (de novo plants) versus plants acquired from another firm. We restrict the analysis to manufacturing plants only. ${ }^{11}$ 20,231 distinct plants are initiated for the first time by the CEOs during our sample period. On average, $20 \%$ of these new plants are de novo investments. We estimate the impact of CEO age on the probability of setting up a de novo plant versus acquiring a plant from another firm in a logit model. The regressions are at the plant level. Results in Table 4.9 show that younger CEOs are more likely to initiate plants through acquisitions than older CEOs. In column 1, we use the continuous age variable, while in column 2 we show results using the age cohorts. CEOs age below 50 are less likely to stage a de novo investment than CEOs age 60 and above. This is consistent with younger CEOs trying to signal their abilities in order to influence labor market's perception of them. We show the marginal effects of age and age cohorts at the end of the table. On average, compared with CEOs 60 and above, younger CEOs below 50 years old are 3 percentage points less likely to build a plant from scratch.

We also find that newly-hired CEOs are more likely to undertake acquisitions than make green-field investments. Firms with better stock performance are also more likely to undertake acquisitions. This is consistent with the idea that well-performing equity can

\footnotetext{
${ }^{11}$ We repeat the analysis using the full LBD sample but the coefficient on CEO age is insignificant.
} 
be used as a mode of payment during acquisitions. Consistent with the Q theory, firms with greater investment prospects (higher Q) are more likely to explore internal growth opportunities by building plants from scratch rather than acquiring plants from other firms. We also experiment by lagging CEO's age two more years to account for the fact that it might take more than one year to build up a plant and our results continue to hold. In sum, we find that, not only are younger CEOs more likely to restructure the existing business portfolios of their firms, they are also more likely to undertake bolder actions through acquisitions and making changes that have bigger impact on firm size.

\subsubsection{Effect of CEO age on plant productivity}

After examining the effects of managerial career concerns on corporate investment decisions, we proceed to investigate whether age impacts firm performance. As a first pass, we regress plant productivity measures on CEO age, controlling for other firm and plant level characteristics in the following specification:

$$
\mathrm{Y}_{i j t}=\alpha+\beta_{1} \text { CEO Age } \text { A }_{j t}+\beta_{2} \text { Tenure }_{j t}+X_{i j t} \gamma+\text { Plant/Industry FE }+\epsilon_{i j t}
$$

where $Y_{i j t}$ denotes the productivity of plant $\mathrm{i}$ of firm $\mathrm{j}$ in year $\mathrm{t}$. We use total factor productivity estimated in Equation (4.1) and the logarithmic transformation of value-added per worker to measure a plant's productivity. Other controls include plant size (measured by the logarithm of total number of employees in the plant), firm size, and firm's number of segments. We control for year fixed effects in all the regressions. In the even-numbered columns, we control also for plant fixed effects while we control for industry fixed effects in the odd-numbered columns. We estimate the above equation for a sizeable sample of 182,555 plant-years available from 1988 to 2005 . Our null hypothesis is that the age of a CEO has no effect on a plant's productivity.

Results are presented in Table 4.10. We present results using the continuous age variable and also age cohort dummy variables. When using the continuous age variable, contrary to what one might expect, a plant is more productive, in terms of TFP, if managed by 
a young CEO. This result not only holds in cross-sectional regressions but also in withinplant regressions when we control of plant fixed effects. Thus, the results are not due to unobservable plant characteristics. When measuring productivity using value-added per worker, we find that young CEOs are associated with higher labor productivity only when using industry fixed effects. The coefficient on age in column 6 , although negative, is not significant at conventional levels when we include plant fixed effects. We lose some statistical significance when we use age cohorts as covariates, with most of the coefficients on the dummy variables indicating younger CEOs have a positive but insignificant effect. Overall, there is some evidence that younger CEOs are associated with better plant productivity, although the results are weak.

In addition to the static effects of CEO age on productivity, we also analyze the performance of investment activities made by CEOs of different ages in a dynamic fashion. We investigate whether CEO age affects the changes in performance of the plants following an acquisition, conditional upon the CEO deciding on an acquisition. Although younger CEOs are influenced more by career concerns, Holmstrom (1999) argues that younger CEOs may also put in more effort to substitute for ability especially in the case when the CEO is unsure about his own talent. Therefore, it is unclear whether younger CEOs will make better acquisitions compared to older CEOs.

We construct a sample of plants that experience ownership changes and follow these plants from three years before to three years after the acquisition. Only plants that experience an ownership change are included. ${ }^{12}{ }^{13}$ We record the age of the CEO at the time of the acquisition and compare the post-acquisition performance made by CEOs of different ages. We estimate the following model at the plant level:

$$
\mathrm{Y}_{i j t}=\alpha+\beta_{1} \text { After }+\beta_{2} \text { After*CEO Age }+X_{i j t} \gamma+\text { Plant/Industry FE }+\epsilon_{i j t}
$$

where $Y_{i j t}$ denotes the productivity of plant $\mathrm{i}$ of firm $\mathrm{j}$ in year $\mathrm{t}$. We use total factor productivity estimated in Equation (4.1) and the logarithm of value-added per worker to

\footnotetext{
${ }^{12}$ We are left with 37,492 plant-year observations for this regression. In a similar regression, Schoar (2002) has has 28118 plant-year observations from 1977 to 1995.

${ }^{13}$ To ensure that we get a comprehensive sample of plant ownership changes, we also obtain takeover information from SDC Platinum.
} 
measure a plant's productivity. In the above equation, CEO age is the acquiring firm's CEO's age at the time of acquisition. "After" is a dummy variable equal to one for the three years after the acquisition, and is zero in the three years before the acquisition. The coefficient on "After" can be interpreted as the average productivity improvement from three years before the acquisition to three years after the acquisition. The coefficient on the interaction term of "After*CEO Age" estimates the differences in later performance for acquisitions made by CEOs of different ages. The baseline effect of CEO Age is absorbed by plant fixed effects.

Results are reported in Table 4.11. The odd-numbered columns report results using industry fixed effects while the even-numbered columns report results using plant fixed effects. We show results using the continuous age variable and age cohort dummy variables. Columns 1, 2, 5, and 6 include the interaction term between "CEO Age" and "After". All the coefficients on interaction terms are negative, which suggests that improvement in post-acquisition performance decreases with age of the acquiring firm's CEO. The effect is especially strong for value-added per worker as evidenced in column 6 . Column 3, 4, 7, and 8 report results when we add interaction terms of "After" with age cohorts - Age under 50 and Age 50-59. Coefficients on both interaction terms are positive but only significant for the interaction between "Age under 50" and "After" when measuring productivity using value-added per employee. In column 8 of Table 4.11, results indicate that compared with acquisitions made by CEOs 60 and above, plants acquired by CEOs younger than 50 enjoy a $10 \%$ premium in terms of labor productivity three years subsequent to the ownership change. However, the results of improved productivity for younger CEOs are not consistent across all specifications.

In sum, we find that plants managed by younger CEOs are at least as productive as those managed by older CEOs in the cross-section. Dynamically, acquisitions made by younger CEOs experience at least as great an improvement relative to that made by older CEOs. These results contradict the hypothesis that CEO career concerns have a distortive effect on investment performance. This is consistent with Yim (2010) who did not find that CEO age has any effect on acquisition profitability. 


\subsubsection{Capital allocation across plants}

In this section, we investigate the effect of career concerns on internal capital allocation across plants. The "trapped administrator" hypothesis by Fox and Staw (1979) asserts that a decision maker may become over-committed to a previously chosen course of action and become reluctant to undertake change even though there may be a need to do so. Prendergast and Stole (1996) argue that a reversal of previous decisions is an admission of mistake and could lead to the CEO being viewed unfavorably by the labor market. We hypothesize that CEOs may become over-committed to the projects he started, leading to favoritism for those plants that he initiated. To the extent that this phenomenon is related to CEOs' need to protect their reputation, this effect is likely to be stronger among younger CEOs with more career concerns. In a related paper, Xuan (2009) finds that capital allocation across different divisions is affected by CEO's private incentives. In this paper, we examine whether capital allocation decisions across plants are affected by CEOs' favoritism towards projects they started.

First, we compare capital expenditures in plants inherited by a CEO with those in plants initiated by him. ${ }^{14}$ On average, in our sample, a typical plant's capital expenditures in a given year are $10.7 \%$ of the value of total capital stock. An "Inherited" plant's investment intensity is slightly less than $10 \%$, whereas that of a "Not-Inherited" plant's is about $12 \%$. The univariate comparison provides support for the CEO favoritism story. Next, we examine whether CEOs are likely to allocate more resources to plants that he initiated in a multivariate analysis.

Table 4.12 reports regression results. The analysis is at the plant-year level. The dependent variable is the capital expenditures scaled by capital stock for the plant. The key variable of interest is Not-Inherited, an indicator variable equal to one if the plant is either built up or acquired from another firm by the current CEO, and zero otherwise. Across all specifications, the coefficient on Not-Inherited is positive and statistically significant. The coefficient of 0.016 implies that a plant that is either built from scratch or acquired

\footnotetext{
${ }^{14}$ We compare the first year a plant is owned by the firm with the year when a CEO first starts to manage the firm. If the former predates the latter, we code this plant as "Inherited" by the CEO, otherwise, the plant is "Not-inherited".
} 
from another firm during the CEO's tenure receives about $1.6 \%$ more capital than a plant "inherited" by the CEO. Results on other control variables are consistent with findings from prior literature. Large firms seem to spread capital more thinly across plants but bigger plants receive more capital. Firms with better investment prospects invest more heavily. More productive plants, as measured by plant TFP, are also investment intensive. After controlling for these variables, the age of the CEO does not affect the allocation of a plant's capital expenditures.

In column 2, we also examine how $\mathrm{CEO}$ age affects this favoritism phenomenon by including an interaction term between CEO age and Not-Inherited. We do not find that younger CEOs are more likely to practice favoritism. Therefore, this favoritism phenomenon seems to stem from a CEO's psychological bias rather than a rational concern for their labor outcomes. In column 3, we test whether CEOs are more likely to allocate capital to failing plants by including an interaction term between Not-Inherit and TFP. Although the interaction is positive, it is insignificant. Hence, despite that CEOs tilt more capital towards plants they themselves initiated, there is virtually no evidence that such allocation is inefficient. In untabulated results, we repeat the analysis using CEO age cohorts instead. Again, the results show that $\mathrm{CEO}$ age does not affect the favoritism phenomenon, with both young and old CEOs equally likely to tilt investment towards plants they initiate.

\subsection{Conclusions}

Younger managers have greater concerns over their future careers. In this paper, we examine how real corporate investment decisions are affected by CEOs' career concerns. We characterize a firm's investment policy to encompass the acquisitions and sales of assets, as well as plant openings and closings. We document that a firm's propensity for investment activities is decreasing in the age of the CEO. Younger CEOs lead a busy life as they are more likely to alter a firm's existing business portfolio. Older CEOs prefer the quiet life and tend to maintain the status quo. We also find that the investment decisions of younger CEOs are bolder as they tend to enter new industries through acquisitions, and that the restructuring activities they undertake are bigger in scale. The career concerns of 
young CEOs do not lead to detrimental effects on firm investment efficiency relative to older CEOs. We do not find that plant productivity improvements post-acquisitions are worse for younger CEOs. Taken together, these results suggest that younger CEOs are busy sending active signals to the managerial labor market by taking on bold and speedy, investment activities compared to those taken by older CEOs. 
Table 4.1: Summary Statistics

The sample consists of 62,414 firm-years after matching data from Compustat, Compact Disclosure, and Longitudinal Business Database (LBD) over the period 1988 to 2005. Panel A describes the firm-level variables while Panel B describes the plant-level variables. Plant-level data in the LBD are aggregated up to form segment level data for each firm, where segments are defined at the 3-digit SIC code. We define four types of restructuring activities. ENTRY (EXIT) is an indicator variable that equals one when the firm enters into a new industry segment (exits from an existing industry segment), and zero otherwise. INCREASE (DECREASE) is an indicator variable that equals one when the firm increases (decreases) the number of plants within at least one of its segments, and zero otherwise. NOCHANGE is an indicator variable that equals one when the firm does not engage in any of the above four types of restructuring activities, and zero otherwise. The definition of the other variables can be found in the Appendix.

\begin{tabular}{|c|c|c|c|c|c|}
\hline \multicolumn{6}{|c|}{ Panel A: Firm-level Variables } \\
\hline & All Firms & NOCHANGE $=1$ & NOCHANGE $=0$ & \multirow{2}{*}{\multicolumn{2}{|c|}{$\begin{array}{l}\text { NOCHANGE }(1)- \\
\text { NOCHANGE }(0)\end{array}$}} \\
\hline & $\mathrm{N}=62414$ & $\mathrm{~N}=26402$ & $\mathrm{~N}=36012$ & & \\
\hline & Mean (SD) & Mean (SD) & Mean (SD) & Difference & p-value \\
\hline \multirow[t]{2}{*}{ NOCHANGE } & 0.423 & & & & \\
\hline & $(0.494)$ & & & & \\
\hline \multirow[t]{2}{*}{ ENTRY } & 0.248 & & 0.429 & & \\
\hline & $(0.432)$ & & $(0.495)$ & & \\
\hline \multirow[t]{2}{*}{ EXIT } & 0.241 & & 0.417 & & \\
\hline & $(0.427)$ & & $(0.493)$ & & \\
\hline \multirow[t]{2}{*}{ INCREASE } & 0.333 & & 0.577 & & \\
\hline & $(0.471)$ & & $(0.494)$ & & \\
\hline \multirow[t]{2}{*}{ DECREASE } & 0.291 & & 0.506 & & \\
\hline & $(0.454)$ & & $(0.500)$ & & \\
\hline \multirow[t]{2}{*}{ CEO Age } & 53.616 & 54.143 & 52.898 & 1.245 & 0.001 \\
\hline & $(8.693)$ & $(8.345)$ & $(9.121)$ & & \\
\hline \multirow[t]{2}{*}{ Tenure $\leq 3$} & 0.460 & 0.466 & 0.457 & 0.009 & 0.010 \\
\hline & $(0.498)$ & $(0.499)$ & $(0.499)$ & & \\
\hline \multirow[t]{2}{*}{ Asset } & 1831 & 388 & 2890 & -2502 & 0.001 \\
\hline & $(5740)$ & $(2032)$ & $(7172)$ & & \\
\hline \multirow[t]{2}{*}{ Tobin's Q } & 2.038 & 2.336 & 1.687 & 0.649 & 0.001 \\
\hline & $(2.735)$ & $(2.295)$ & $(1.352)$ & & \\
\hline \multirow[t]{2}{*}{ ROA } & 0.056 & 0.001 & 0.116 & -0.115 & 0.001 \\
\hline & $(0.317)$ & $(0.424)$ & $(0.183)$ & & \\
\hline \multirow[t]{2}{*}{ Stock Returns } & 0.187 & 0.177 & 0.162 & 0.015 & 0.001 \\
\hline & $(0.870)$ & $(0.843)$ & $(0.630)$ & & \\
\hline \multirow[t]{2}{*}{ Cash } & 0.160 & 0.225 & 0.112 & 0.113 & 0.001 \\
\hline & $(0.205)$ & $(0.247)$ & $(0.150)$ & & \\
\hline \multirow[t]{2}{*}{ No. of Segments } & 3.976 & 1.803 & 5.569 & -3.766 & 0.001 \\
\hline & $(4.483)$ & $(1.550)$ & $(5.204)$ & & \\
\hline \multirow[t]{2}{*}{ No. of Plants } & 63.936 & 6.497 & 106.062 & -99.565 & 0.001 \\
\hline & $(171.444)$ & $(28.308)$ & $(214.868)$ & & \\
\hline
\end{tabular}


Table 4.2: Effect of Age on Investment Activity

This table presents logistic regressions of firm restructuring activities on CEO age. Plant-level data in the LBD are aggregated up to form segment level data for each firm, where segments are defined at the 3-digit SIC code. We define four types of restructuring activities. ENTRY (EXIT) is an indicator variable that equals one when the firm enters into a new industry segment (exits from an existing industry segment), and zero otherwise. INCREASE (DECREASE) is an indicator variable that equals to one when the firm increases (decreases) the number of plants within at least one of its segments, and zero otherwise. NOCHANGE is an indicator variable that equals one when the firm does not engage in any of the above four types of restructuring activities, and zero otherwise. $\mathrm{CEO}$ age and other accounting variables are lagged by one year. Definitions of the variables can be found in the Appendix. The last row of the table calculates the marginal effect of age, evaluated at the mean values of the independent variables. All regressions include industry and year fixed effects. Standard errors clustered at the firm level are reported in parentheses. Statistical significance at the $1 \%, 5 \%$, and $10 \%$ level is indicated by $* * *, * *$, and $*$, respectively.

\begin{tabular}{lccccc}
\hline & NOCHANGE & ENTRY & EXIT & INCREASE & DECREASE \\
& $(1)$ & $(2)$ & $(3)$ & $(4)$ & $(5)$ \\
\hline CEO Age & $0.011^{* * *}$ & $-0.008^{* * *}$ & $-0.009^{* * *}$ & $-0.006^{* * *}$ & -0.002 \\
& $(0.002)$ & $(0.001)$ & $(0.002)$ & $(0.002)$ & $(0.002)$ \\
Tenure $\leq 3$ & -0.032 & -0.012 & $0.055^{* *}$ & $-0.063^{* *}$ & $0.077^{* * *}$ \\
& $(0.027)$ & $(0.025)$ & $(0.028)$ & $(0.026)$ & $(0.028)$ \\
Log(Asset) & $-0.147^{* * *}$ & $0.173^{* * *}$ & $-0.040^{* * *}$ & $0.165^{* * *}$ & $0.028^{* *}$ \\
Tobin's Q & $(0.011)$ & $(0.010)$ & $(0.011)$ & $(0.011)$ & $(0.013)$ \\
& $-0.020^{* * *}$ & $0.026^{* * *}$ & -0.003 & $0.038^{* * *}$ & $-0.096^{* * *}$ \\
ROA & $(0.005)$ & $(0.005)$ & $(0.006)$ & $(0.007)$ & $(0.016)$ \\
& $-0.220^{* * *}$ & $0.338^{* * *}$ & $-0.215^{* * *}$ & $1.781^{* * *}$ & $-0.468^{* * *}$ \\
Stock Returns & $(0.053)$ & $(0.066)$ & $(0.047)$ & $(0.104)$ & $(0.057)$ \\
& -0.008 & $0.031^{* *}$ & -0.021 & $0.057^{* * *}$ & $-0.071^{* * *}$ \\
Cash & $(0.014)$ & $(0.014)$ & $(0.017)$ & $(0.014)$ & $(0.020)$ \\
& $0.231^{* * *}$ & $-0.132^{*}$ & 0.134 & $-0.263^{* * *}$ & $-0.475^{* * *}$ \\
Log(No. of Segments) & $(0.074)$ & $(0.077)$ & $(0.083)$ & $(0.090)$ & $(0.101)$ \\
& $-0.877^{* * *}$ & $0.747^{* * *}$ & $2.366^{* * *}$ & $0.725^{* * *}$ & $0.890^{* * *}$ \\
Log(No. of Plants) & $(0.044)$ & $(0.032)$ & $(0.039)$ & $(0.033)$ & $(0.039)$ \\
& $-1.013^{* * *}$ & $0.038^{* * *}$ & $-0.084^{* * *}$ & $0.431^{* * *}$ & $0.820^{* * *}$ \\
& $(0.023)$ & $(0.015)$ & $(0.017)$ & $(0.016)$ & $(0.023)$ \\
\hline Observations & 62414 & 62414 & 62414 & 62414 & 62414 \\
Industry FE & Yes & Yes & Yes & Yes & Yes \\
Year FE & Yes & Yes & Yes & Yes & Yes \\
Pseudo R & 0.41 & 0.18 & 0.29 & 0.31 & 0.35 \\
ME of AGE & 0.003 & -0.001 & -0.002 & -0.001 & -0.001 \\
\hline
\end{tabular}


Table 4.3: Effect of Age on Investment Activity using Age Cohorts

This table presents logistic regressions of firm restructuring activities on CEO age. We create three cohorts of CEOs by age: Under 50, between 50 and 59, and 60 and above. In the regression, the omitted category is CEOs aged 60 and above. CEO age and other accounting variables are lagged by one year. Definitions of the variables can be found in the Appendix. P-values are from testing for the equality of coefficients on indicator variable for CEO under 50 and CEO aged between 50 and 59. All regressions include industry and year fixed effects. Standard errors clustered at the firm level are reported in parentheses. Statistical significance at the 1\%,5\%, and $10 \%$ level is indicated by $* * *, * *$, and $*$, respectively.

\begin{tabular}{|c|c|c|c|c|c|}
\hline & $\begin{array}{l}\text { NOCHANGE } \\
\text { (1) }\end{array}$ & $\begin{array}{l}\text { ENTRY } \\
(2)\end{array}$ & $\begin{array}{c}\text { EXIT } \\
(3)\end{array}$ & $\begin{array}{c}\text { INCREASE } \\
(4)\end{array}$ & $\begin{array}{c}\text { DECREASE } \\
(5)\end{array}$ \\
\hline \multirow[t]{2}{*}{ Age under 50} & $-0.199^{* * *}$ & $0.151^{* * *}$ & $0.214^{* * *}$ & $0.117^{* * *}$ & 0.027 \\
\hline & $(0.037)$ & $(0.033)$ & $(0.036)$ & $(0.035)$ & $(0.038)$ \\
\hline \multirow[t]{2}{*}{ Age 50-59 } & $-0.112^{* * *}$ & $0.074^{* * *}$ & $0.105^{* * *}$ & $0.062^{* *}$ & 0.016 \\
\hline & $(0.034)$ & $(0.028)$ & $(0.032)$ & $(0.030)$ & $(0.033)$ \\
\hline \multirow[t]{2}{*}{ Tenure $\leq 3$} & -0.042 & -0.003 & $0.049^{*}$ & $-0.056^{* *}$ & $0.079^{* * *}$ \\
\hline & $(0.027)$ & $(0.024)$ & $(0.028)$ & $(0.026)$ & $(0.028)$ \\
\hline \multirow[t]{2}{*}{ Log(Asset) } & $-0.147^{* * *}$ & $0.173^{* * *}$ & $-0.040^{* * *}$ & $0.165^{* * *}$ & $0.028^{* *}$ \\
\hline & $(0.011)$ & $(0.010)$ & $(0.011)$ & $(0.011)$ & $(0.013)$ \\
\hline \multirow[t]{2}{*}{ Tobin's Q } & $-0.021^{* * *}$ & $0.026^{* * *}$ & -0.003 & $0.038^{* * *}$ & $-0.096^{* * *}$ \\
\hline & $(0.005)$ & $(0.005)$ & $(0.006)$ & $(0.007)$ & $(0.016)$ \\
\hline \multirow[t]{2}{*}{ ROA } & $-0.220^{* * *}$ & $0.338^{* * *}$ & $-0.215^{* * *}$ & $1.782^{* * *}$ & $-0.468^{* * *}$ \\
\hline & $(0.053)$ & $(0.066)$ & $(0.047)$ & $(0.104)$ & $(0.057)$ \\
\hline \multirow[t]{2}{*}{ Stock Returns } & -0.009 & $0.031^{* *}$ & -0.021 & $0.057^{* * *}$ & $-0.071^{* * *}$ \\
\hline & $(0.014)$ & $(0.014)$ & $(0.017)$ & $(0.014)$ & $(0.020)$ \\
\hline \multirow[t]{2}{*}{ Cash } & $0.227^{* * *}$ & $-0.130^{*}$ & 0.132 & $-0.264^{* * *}$ & $-0.475^{* * *}$ \\
\hline & $(0.075)$ & $(0.077)$ & $(0.083)$ & $(0.090)$ & $(0.102)$ \\
\hline \multirow[t]{2}{*}{$\log$ (No. of Segments) } & $-0.873^{* * *}$ & $0.744^{* * *}$ & $2.367^{* * *}$ & $0.723^{* * *}$ & $0.889^{* * *}$ \\
\hline & $(0.044)$ & $(0.032)$ & $(0.039)$ & $(0.033)$ & $(0.039)$ \\
\hline \multirow[t]{2}{*}{ Log(No. of Plants) } & $-1.011^{* * *}$ & $0.037^{* *}$ & $-0.084^{* * *}$ & $0.430^{* * *}$ & $0.820^{* * *}$ \\
\hline & $(0.023)$ & $(0.015)$ & $(0.017)$ & $(0.016)$ & $(0.023)$ \\
\hline Observations & 62414 & 62414 & 62414 & 62414 & 62414 \\
\hline Industry FE & Yes & Yes & Yes & Yes & Yes \\
\hline Year FE & Yes & Yes & Yes & Yes & Yes \\
\hline Pseudo $\mathrm{R}^{2}$ & 0.41 & 0.18 & 0.29 & 0.31 & 0.35 \\
\hline P-value & 0.001 & 0.001 & 0.001 & 0.060 & 0.750 \\
\hline ME of Age under 50 & -0.059 & 0.026 & 0.037 & 0.037 & 0.008 \\
\hline ME of Age 50-59 & -0.029 & 0.011 & 0.015 & 0.015 & 0.004 \\
\hline
\end{tabular}


Table 4.4: Effect of Age on Investment Activity: Firm Fixed Effects

This table presents ordinary least squares (OLS) regressions of firm restructuring activities on CEO age controlling for firm fixed effects. We define four types of restructuring activities. ENTRY (EXIT) is an indicator variable that equals one when the firm enters into a new industry segment (exits from an existing industry segment), and zero otherwise. INCREASE (DECREASE) is an indicator variable that equals one when the firm increases (decreases) the number of plants within at least one of its segments, and zero otherwise. NOCHANGE is an indicator variable that equals one when the firm does not engage in any of the above four types of restructuring activities, and zero otherwise. CEO age and other accounting variables are lagged by one year. Definitions of the variables can be found in the Appendix. All regressions include year and firm fixed effects. Standard errors clustered at the firm level are reported in parentheses. Statistical significance at the $1 \%, 5 \%$, and $10 \%$ level is indicated by ${ }^{* * *},{ }^{* *}$, and ${ }^{*}$, respectively.

\begin{tabular}{lccccc}
\hline & NOCHANGE & ENTRY & EXIT & INCREASE & DECREASE \\
& $(1)$ & $(2)$ & $(3)$ & $(4)$ & $(5)$ \\
\hline CEO Age & $0.002^{* * *}$ & $-0.001^{* * *}$ & $-0.002^{* * *}$ & $-0.001^{* * *}$ & -0.001 \\
& $(0.000)$ & $(0.000)$ & $(0.000)$ & $(0.000)$ & $(0.000)$ \\
Tenure $\leq 3$ & $-0.012^{* * *}$ & $0.020^{* * *}$ & $0.011^{* *}$ & 0.003 & 0.003 \\
& $(0.004)$ & $(0.005)$ & $(0.004)$ & $(0.005)$ & $(0.004)$ \\
Log(Asset) & -0.003 & $0.012^{* * *}$ & $-0.034^{* * *}$ & 0.006 & $-0.015^{* * *}$ \\
& $(0.004)$ & $(0.004)$ & $(0.004)$ & $(0.004)$ & $(0.004)$ \\
Tobin's Q & $-0.003^{* * *}$ & $0.002^{* * *}$ & $-0.001^{*}$ & $0.006^{* * *}$ & $-0.003^{* * *}$ \\
& $(0.001)$ & $(0.001)$ & $(0.001)$ & $(0.001)$ & $(0.001)$ \\
ROA & $-0.015^{* * *}$ & $0.034^{* * *}$ & $-0.024^{* *}$ & $0.082^{* * *}$ & $-0.054^{* * *}$ \\
& $(0.007)$ & $(0.007)$ & $(0.011)$ & $(0.008)$ & $(0.007)$ \\
Stock Returns & $0.005^{* *}$ & 0.002 & -0.002 & 0.001 & $-0.005^{* * *}$ \\
& $(0.002)$ & $(0.002)$ & $(0.002)$ & $(0.002)$ & $(0.002)$ \\
Cash & 0.003 & $0.036^{* *}$ & $0.041^{* * *}$ & 0.002 & -0.015 \\
& $(0.018)$ & $(0.017)$ & $(0.015)$ & $(0.014)$ & $(0.013)$ \\
Log(No. of Segments) & $-0.093^{* * *}$ & $-0.154^{* * *}$ & $0.575^{* * *}$ & $0.225^{* * *}$ & -0.015 \\
& $(0.005)$ & $(0.013)$ & $(0.011)$ & $(0.012)$ & $(0.012)$ \\
Log(No. of Plants) & $-0.087^{* * *}$ & $0.037^{* * *}$ & $-0.066^{* * *}$ & $-0.033^{* * *}$ & $0.226^{* * *}$ \\
& $(0.005)$ & $(0.006)$ & $(0.005)$ & $(0.007)$ & $(0.007)$ \\
\hline Observations & 62414 & 62414 & 62414 & 62414 & 62414 \\
Firm FE & Yes & Yes & Yes & Yes & Yes \\
Year FE & Yes & Yes & Yes & Yes & Yes \\
Adj. R ${ }^{2}$ & 0.48 & 0.16 & 0.28 & 0.37 & 0.42 \\
\hline
\end{tabular}




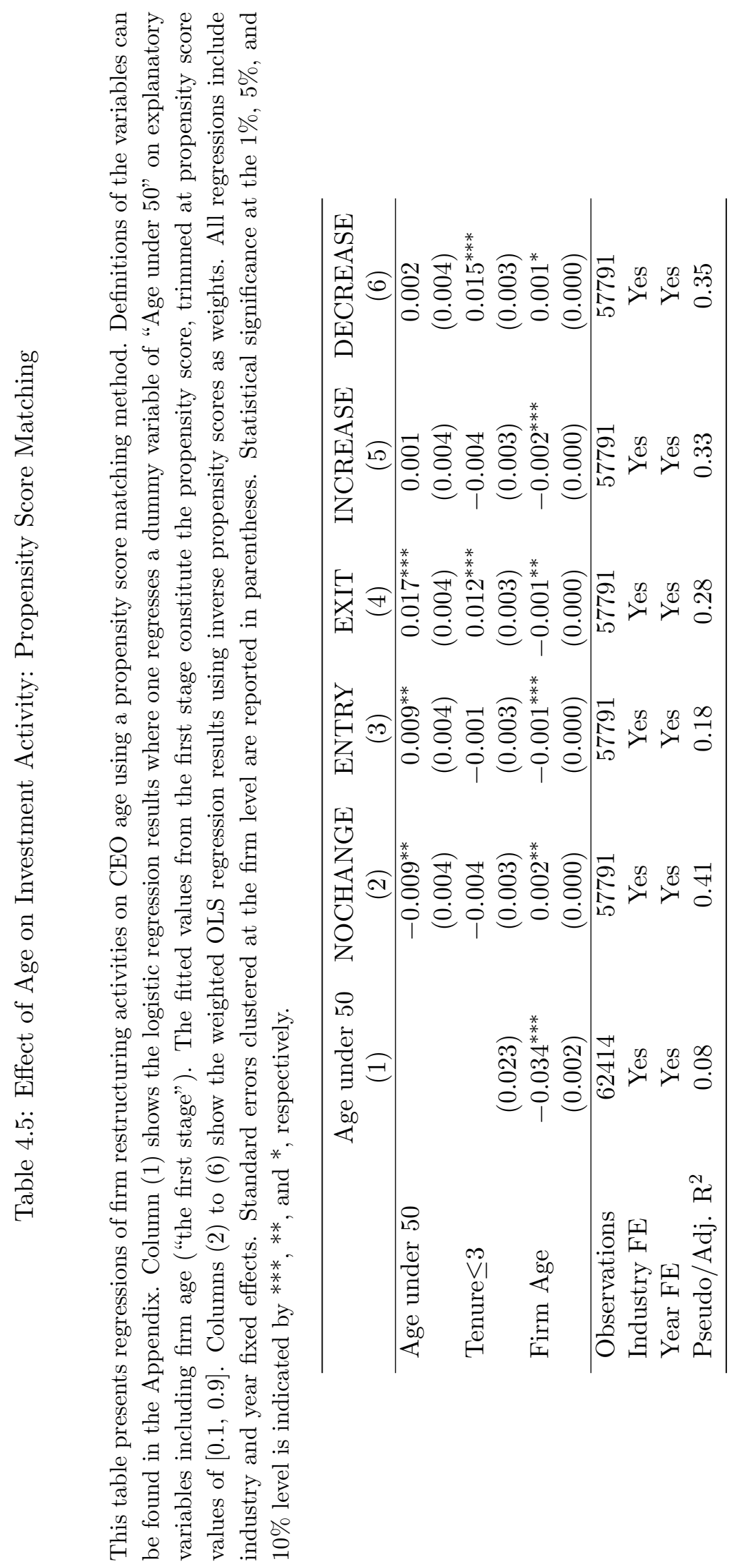


Table 4.6: Effect of Age on Investment Activity: CEO Fixed Effects

This table presents ordinary least squares (OLS) regressions of firm restructuring activities on CEO age controlling for CEO fixed effects. We define four types of restructuring activities. ENTRY (EXIT) is an indicator variable that equals one when the firm enters into a new industry segment (exits from an existing industry segment), and zero otherwise. INCREASE (DECREASE) is an indicator variable that equals one when the firm increases (decreases) the number of plants within at least one of its segments, and zero otherwise. NOCHANGE is an indicator variable that equals one when the firm does not engage in any of the above four types of restructuring activities, and zero otherwise. CEO age and other accounting variables are lagged by one year. Definitions of the variables can be found in the Appendix. All regressions include CEO fixed effects. Standard errors clustered at the firm level are reported in parentheses. Statistical significance at the 1\%, 5\%, and $10 \%$ level is indicated by ${ }^{* * *}, * *$, and $*$, respectively.

\begin{tabular}{lccccc}
\hline & NOCHANGE & ENTRY & EXIT & INCREASE & DECREASE \\
& $(1)$ & $(2)$ & $(3)$ & $(4)$ & $(5)$ \\
\hline CEO Age & $0.014^{* * *}$ & $-0.018^{* * *}$ & $-0.013^{* * *}$ & $-0.011^{* * *}$ & $-0.002^{* *}$ \\
& $(0.001)$ & $(0.001)$ & $(0.001)$ & $(0.001)$ & $(0.001)$ \\
Tenure $\leq 3$ & $0.018^{* * *}$ & $-0.019^{* * *}$ & $-0.024^{* * *}$ & $-0.010^{* *}$ & -0.006 \\
& $(0.005)$ & $(0.005)$ & $(0.005)$ & $(0.005)$ & $(0.005)$ \\
Log(Asset) & $-0.027^{* * *}$ & $0.052^{* * *}$ & $-0.014^{* * *}$ & $0.039^{* * *}$ & $-0.015^{* * *}$ \\
& $(0.004)$ & $(0.004)$ & $(0.004)$ & $(0.004)$ & $(0.004)$ \\
Tobin's Q & $-0.003^{* * *}$ & $0.002^{* * *}$ & -0.001 & $0.006^{* * *}$ & $-0.003^{* * *}$ \\
& $(0.001)$ & $(0.001)$ & $(0.001)$ & $(0.001)$ & $(0.001)$ \\
ROA & -0.001 & 0.013 & $-0.037^{* * *}$ & $0.064^{* * *}$ & $-0.051^{* * *}$ \\
& $(0.009)$ & $(0.010)$ & $(0.013)$ & $(0.009)$ & $(0.009)$ \\
Stock Returns & 0.002 & $0.005^{* *}$ & -0.001 & 0.003 & -0.003 \\
& $(0.002)$ & $(0.002)$ & $(0.002)$ & $(0.003)$ & $(0.002)$ \\
Cash & 0.013 & 0.016 & $0.053^{* * *}$ & 0.001 & -0.003 \\
& $(0.017)$ & $(0.019)$ & $(0.019)$ & $(0.018)$ & $(0.013)$ \\
Log(No. of Segments) & $-0.074^{* * *}$ & $-0.268^{* * *}$ & $0.628^{* * *}$ & $0.214^{* * *}$ & $-0.030^{* * *}$ \\
& $(0.005)$ & $(0.006)$ & $(0.005)$ & $(0.010)$ & $(0.009)$ \\
Log(No. of Plants) & $-0.093^{* * *}$ & $0.062^{* * *}$ & $-0.067^{* * *}$ & $-0.038^{* * *}$ & $0.232^{* * *}$ \\
& $(0.009)$ & $(0.005)$ & $(0.005)$ & $(0.005)$ & $(0.005)$ \\
\hline Observations & 62414 & 62414 & 62414 & 62414 & 62414 \\
CEO FE & Yes & Yes & Yes & Yes & Yes \\
Adj. R R $^{2}$ & 0.49 & 0.19 & 0.29 & 0.38 & 0.42 \\
\hline
\end{tabular}


Table 4.7: Effect of Age on Employment Growth

This table presents ordinary least squares (OLS) regressions of firm's employment growth on CEO age. Employment(Entry) is the ratio of number of employees in the new segments to the firm's total employment in the previous year. Only firms which enter at least one new segment are included. Employment(Exit) is the ratio of number of employees in the exiting segments to the firm's total employment in the previous year. Only firms which exit at least one new segment are included. Employment Growth is the difference between a firm's current year's employment and previous year's employment divided by previous year's employment. CEO age and other accounting variables are lagged by one year. Definitions of the variables can be found in the Appendix. All regressions include industry and year fixed effects. P-values are from testing for the equality of coefficients on indicator variable for CEO under 50 and CEO aged between 50 and 59. Standard errors clustered at the firm level are reported in parentheses. Statistical significance at the $1 \%, 5 \%$, and $10 \%$ level is indicated by ${ }^{* * *},{ }^{* *}$, and ${ }^{*}$, respectively.

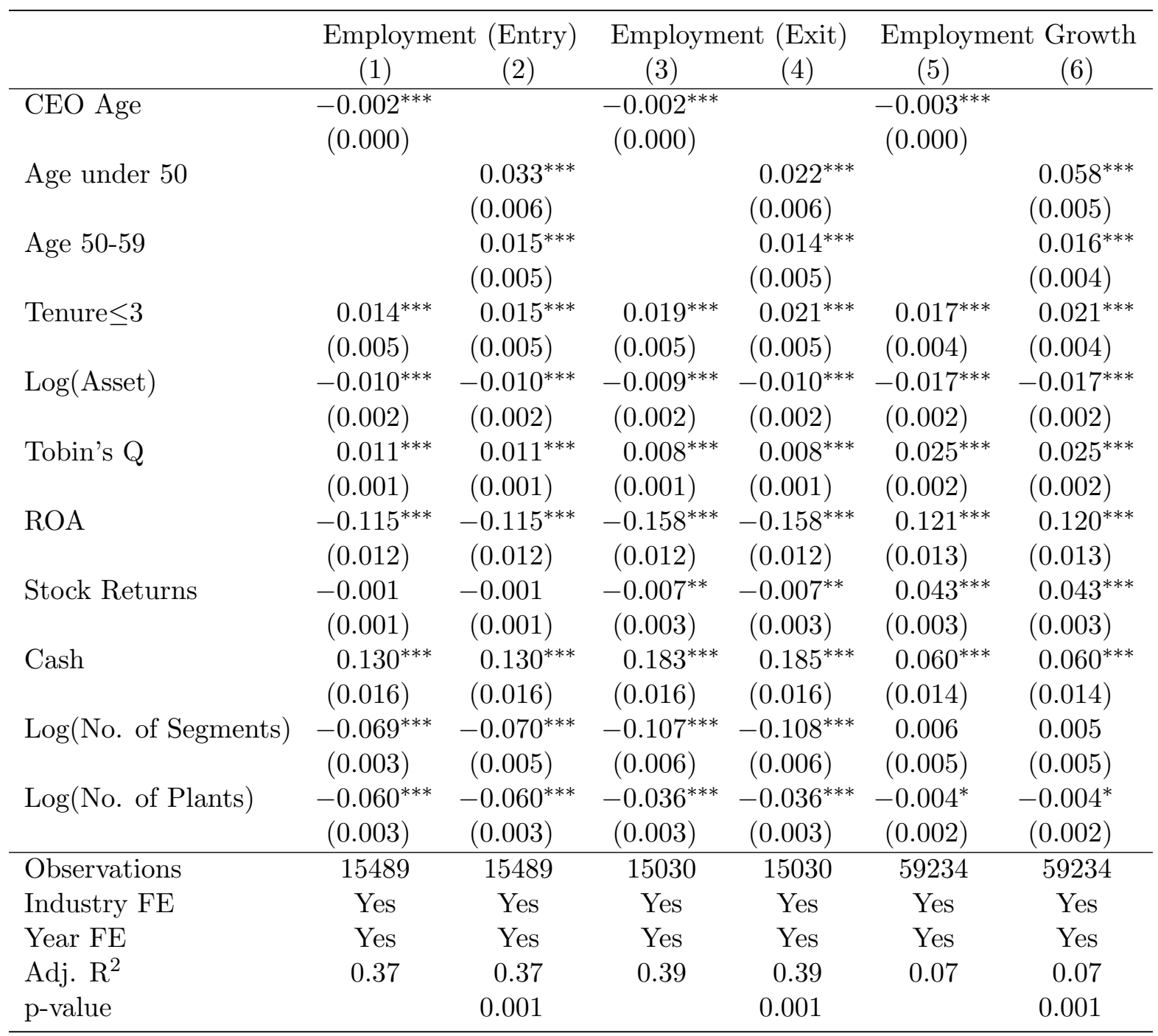


Table 4.8: Effect of Age on Capital Expenditures and R\&D Expenditures

This table presents ordinary least squares (OLS) regressions of firm's capital expenditures and research and development (R\&D) expenditures on CEO age. Capital Expenditure is the ratio of firm's capital expenditures to previous year's assets. R\&D Expenditure is the ratio of $R \& D$ to previous year's book assets. Both variables are from Compustat. CEO age and other accounting variables are lagged by one year. Definitions of the variables can be found in the Appendix. All regressions include industry and year fixed effects. P-values are from testing for the equality of coefficients on indicator variable for CEO under 50 and CEO aged between 50 and 59. Standard errors clustered at the firm level are reported in parentheses. Statistical significance at the $1 \%, 5 \%$, and $10 \%$ level is indicated by ${ }^{* * *}, * *$, and $*$, respectively.

\begin{tabular}{|c|c|c|c|c|}
\hline & \multicolumn{2}{|c|}{ Capital Expenditure*10 } & \multicolumn{2}{|c|}{ R\&D Expenditure*10 } \\
\hline & (1) & $(2)$ & (3) & (4) \\
\hline CEO Age & $\begin{array}{c}-0.004^{* * *} \\
(0.001)\end{array}$ & & $\begin{array}{c}-0.002^{* * *} \\
(0.001)\end{array}$ & \\
\hline Age under 50 & & $\begin{array}{l}0.076^{* * *} \\
(0.014)\end{array}$ & & $\begin{array}{l}0.053^{* * *} \\
(0.016)\end{array}$ \\
\hline Age 50-59 & & $\begin{array}{c}0.015 \\
(0.011)\end{array}$ & & $\begin{array}{l}0.055^{* * *} \\
(0.012)\end{array}$ \\
\hline Tenure $\leq 3$ & $\begin{array}{c}-0.004 \\
(0.009)\end{array}$ & $\begin{array}{c}-0.001 \\
(0.009)\end{array}$ & $\begin{array}{c}-0.035^{* * *} \\
(0.011)\end{array}$ & $\begin{array}{c}-0.034^{* * *} \\
(0.011)\end{array}$ \\
\hline Log(Asset) & $\begin{array}{l}0.067^{* * *} \\
(0.005)\end{array}$ & $\begin{array}{l}0.067^{* * *} \\
(0.005)\end{array}$ & $\begin{array}{l}0.047^{* * *} \\
(0.006)\end{array}$ & $\begin{array}{l}0.047^{* * *} \\
(0.006)\end{array}$ \\
\hline Tobin's Q & $\begin{array}{l}0.071^{* * *} \\
(0.004)\end{array}$ & $\begin{array}{l}0.072^{* * *} \\
(0.004)\end{array}$ & $\begin{array}{l}0.129^{* * *} \\
(0.007)\end{array}$ & $\begin{array}{l}0.129^{* * *} \\
(0.007)\end{array}$ \\
\hline $\mathrm{ROA}$ & $\begin{array}{l}0.341^{* * *} \\
(0.035)\end{array}$ & $\begin{array}{l}0.341^{* * *} \\
(0.035)\end{array}$ & $\begin{array}{c}-1.587^{* * *} \\
(0.061)\end{array}$ & $\begin{array}{c}-1.587^{* * *} \\
(0.061)\end{array}$ \\
\hline Stock Returns & $\begin{array}{l}0.019^{* * *} \\
(0.006)\end{array}$ & $\begin{array}{l}0.020^{* * *} \\
(0.006)\end{array}$ & $\begin{array}{l}0.047^{* * *} \\
(0.008)\end{array}$ & $\begin{array}{l}0.047^{* * *} \\
(0.008)\end{array}$ \\
\hline Cash & $\begin{array}{c}-0.350^{* * *} \\
(0.029)\end{array}$ & $\begin{array}{c}-0.351^{* * *} \\
(0.029)\end{array}$ & $\begin{array}{l}0.878^{* * *} \\
(0.052)\end{array}$ & $\begin{array}{l}0.880^{* * *} \\
(0.052)\end{array}$ \\
\hline Log(No. of Segments) & $\begin{array}{c}-0.123^{* * *} \\
(0.014)\end{array}$ & $\begin{array}{c}-0.124^{* * *} \\
(0.014)\end{array}$ & $\begin{array}{c}-0.092^{* * *} \\
(0.012)\end{array}$ & $\begin{array}{c}-0.092^{\text {*** }} \\
(0.012)\end{array}$ \\
\hline Log(No. of Plants) & $\begin{array}{c}-0.040^{* * *} \\
(0.007)\end{array}$ & $\begin{array}{c}-0.040^{* * *} \\
(0.007)\end{array}$ & $\begin{array}{c}-0.001 \\
(0.006)\end{array}$ & $\begin{array}{c}-0.002 \\
(0.006)\end{array}$ \\
\hline Observations & 62414 & 62414 & 62414 & 62414 \\
\hline Industry FE & Yes & Yes & Yes & Yes \\
\hline Year FE & Yes & Yes & Yes & Yes \\
\hline Adj. $R^{2}$ & 0.28 & 0.28 & 0.56 & 0.56 \\
\hline P-value & & 0.001 & & 0.88 \\
\hline
\end{tabular}


Table 4.9: De Novo vs. Acquisition

The table shows results from logistic regressions that examine how CEO age affects firm's choice between acquiring a plant from another firm and building one from scratch. The sample consists of all manufacturing plants the first year that were started by the CEO during our sample period. The dependent variable is a dummy variable that equals one if the plant is built from scratch, i.e., De Novo $=1$, and zero if the plant is acquired from another company. CEO age and other accounting variables are lagged by one year. Definitions of the variables can be found in the Appendix. All specifications control of industry and year fixed effects. P-values are from testing for the equality of coefficients on indicator variable for CEO under 50 and CEO aged between 50 and 59. Standard errors clustered at the firm level are reported in parentheses. Statistical significance at the $1 \%, 5 \%$, and $10 \%$ level is indicated by ${ }^{* * *},{ }^{* *}$, and ${ }^{*}$, respectively.

\begin{tabular}{|c|c|c|}
\hline & \multicolumn{2}{|c|}{ De Novo } \\
\hline & (1) & $(2)$ \\
\hline CEO Age & $\begin{array}{l}0.015^{* * *} \\
(0.003)\end{array}$ & \\
\hline Age Under 50 & & $\begin{array}{c}-0.214^{* * *} \\
(0.059)\end{array}$ \\
\hline Age 50-59 & & $\begin{array}{c}-0.253^{* * *} \\
(0.043)\end{array}$ \\
\hline Tenure $\leq 3$ & $\begin{array}{c}-0.287^{* * *} \\
(0.046)\end{array}$ & $\begin{array}{c}-0.303^{* * *} \\
(0.046)\end{array}$ \\
\hline Log(Asset) & $\begin{array}{c}-0.075^{* * *} \\
(0.016)\end{array}$ & $\begin{array}{c}-0.075^{* * *} \\
(0.016)\end{array}$ \\
\hline Tobin's Q & $\begin{array}{l}0.067^{* * *} \\
(0.020)\end{array}$ & $\begin{array}{c}0.065^{* * *} \\
(0.020)\end{array}$ \\
\hline $\mathrm{ROA}$ & $\begin{array}{c}0.004 \\
(0.164)\end{array}$ & $\begin{array}{c}0.023 \\
(0.162)\end{array}$ \\
\hline Stock Returns & $\begin{array}{c}-0.262^{* * *} \\
(0.046)\end{array}$ & $\begin{array}{c}-0.257^{* * *} \\
(0.046)\end{array}$ \\
\hline Cash & $\begin{array}{c}-0.271 \\
(0.208)\end{array}$ & $\begin{array}{c}-0.257 \\
(0.207)\end{array}$ \\
\hline Log(No. of Segments) & $\begin{array}{l}0.083^{* * *} \\
(0.033)\end{array}$ & $\begin{array}{c}0.098^{* * *} \\
(0.033)\end{array}$ \\
\hline Observations & 20231 & 20231 \\
\hline Industry FE & Yes & Yes \\
\hline Year FE & Yes & Yes \\
\hline Pseudo $\mathrm{R}^{2}$ & 0.08 & 0.08 \\
\hline ME of AGE & 0.002 & \\
\hline $\mathrm{P}$-value & & 0.62 \\
\hline ME of Age under 50 & & -0.030 \\
\hline ME of Age $50-59$ & & -0.035 \\
\hline
\end{tabular}




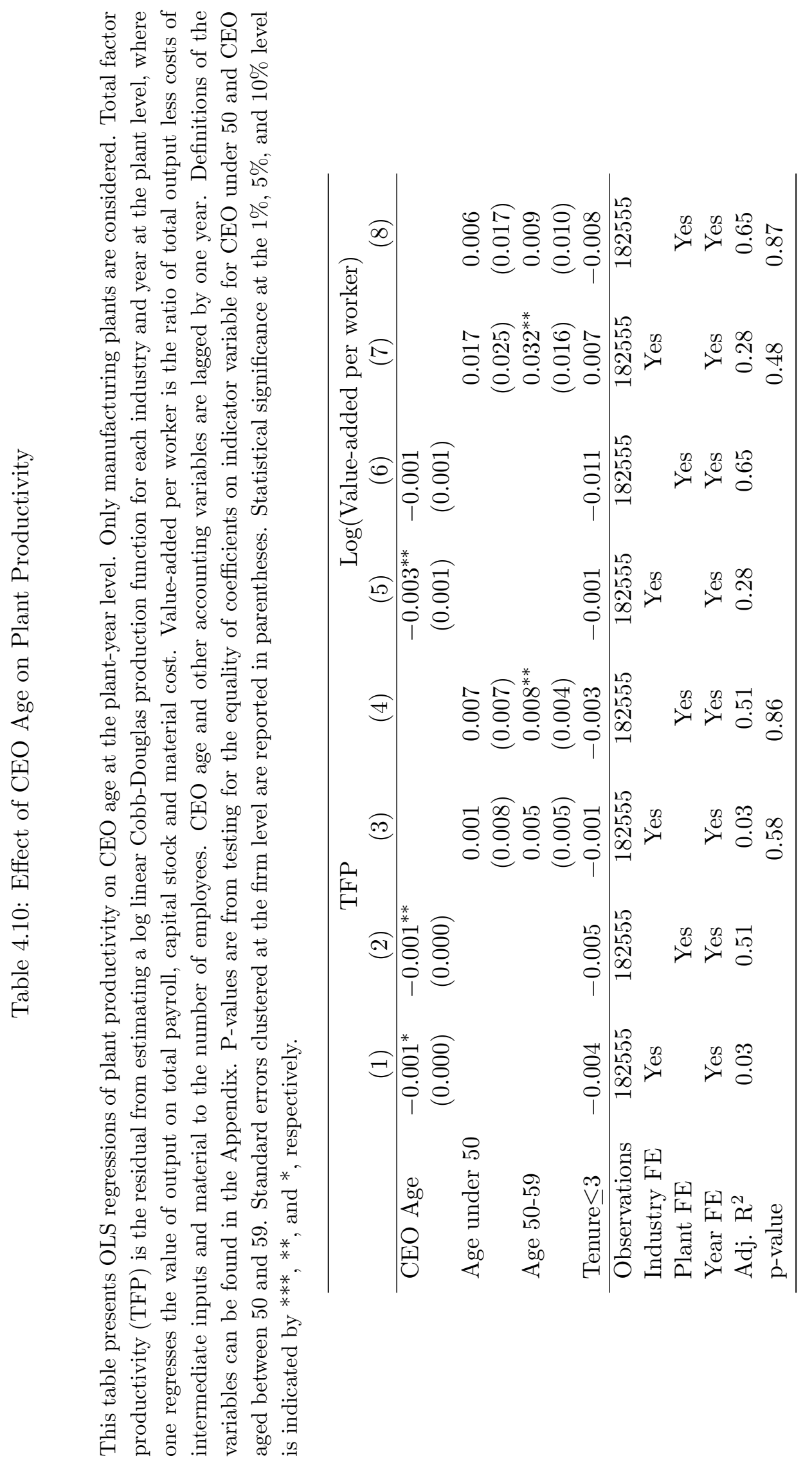




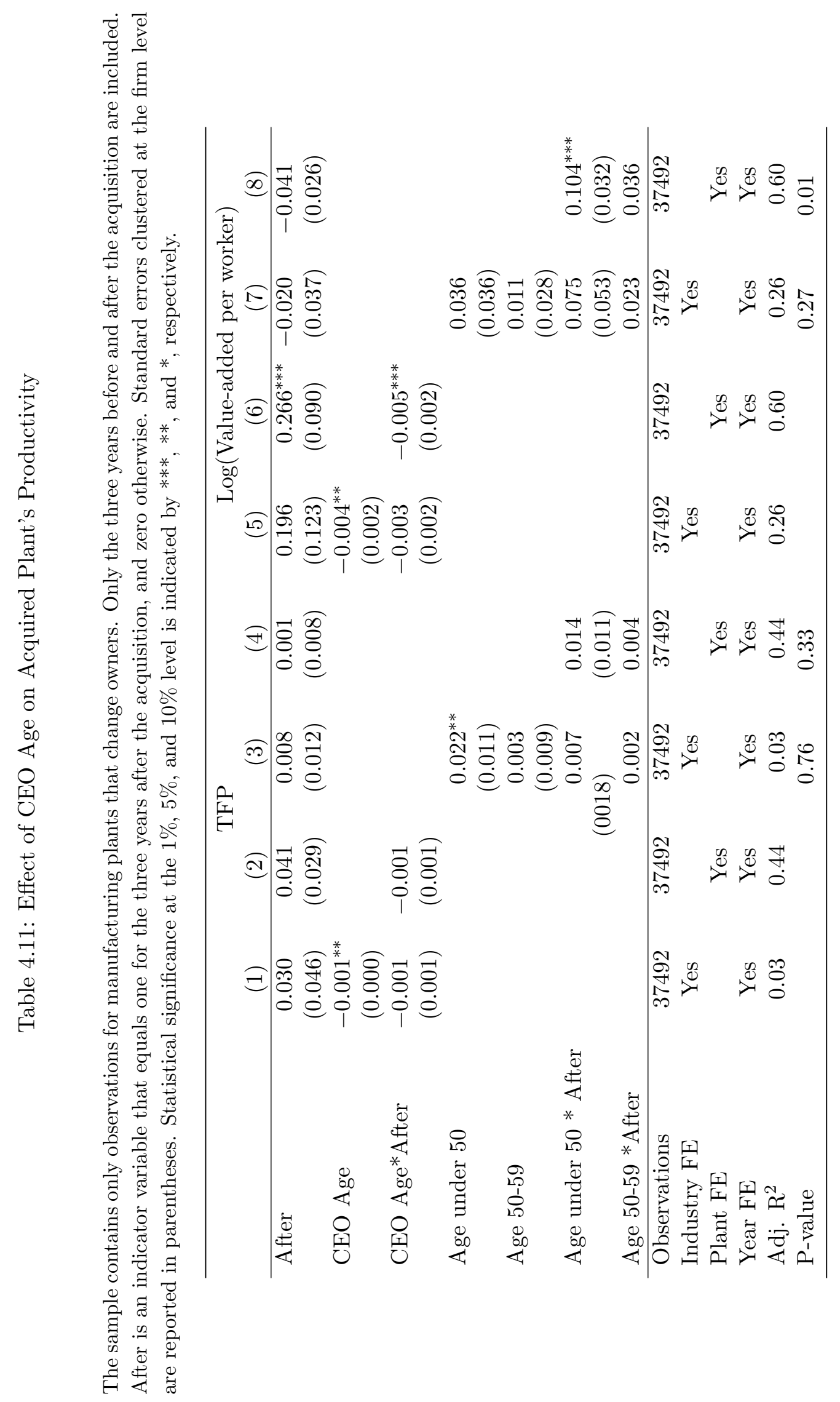


Table 4.12: Capital Expenditure: Inherited vs. Not-Inherited Plant

This table presents OLS regressions of capital expenditures on an indicator variable, Not-Inherited, controlling for other plant and firm level characteristics. The dependent variable is plant-level capital expenditures scaled by capital stock. Not-Inherited is equal to one if the current CEO either builds the plant from scratch, or acquires the plant from another firm, and zero if the CEO inherits the plant from his predecessor. Only manufacturing plants are considered. CEO age and other accounting variables are lagged by one year. Definitions of the variables can be found in the Appendix. P-values are from testing for the equality of coefficients on indicator variable for CEO under 50 and CEO aged between 50 and 59. Standard errors clustered at the firm level are reported in parentheses. Statistical significance at the $1 \%, 5 \%$, and $10 \%$ level is indicated by ${ }^{* * *},{ }^{* *}$, and ${ }^{*}$, respectively.

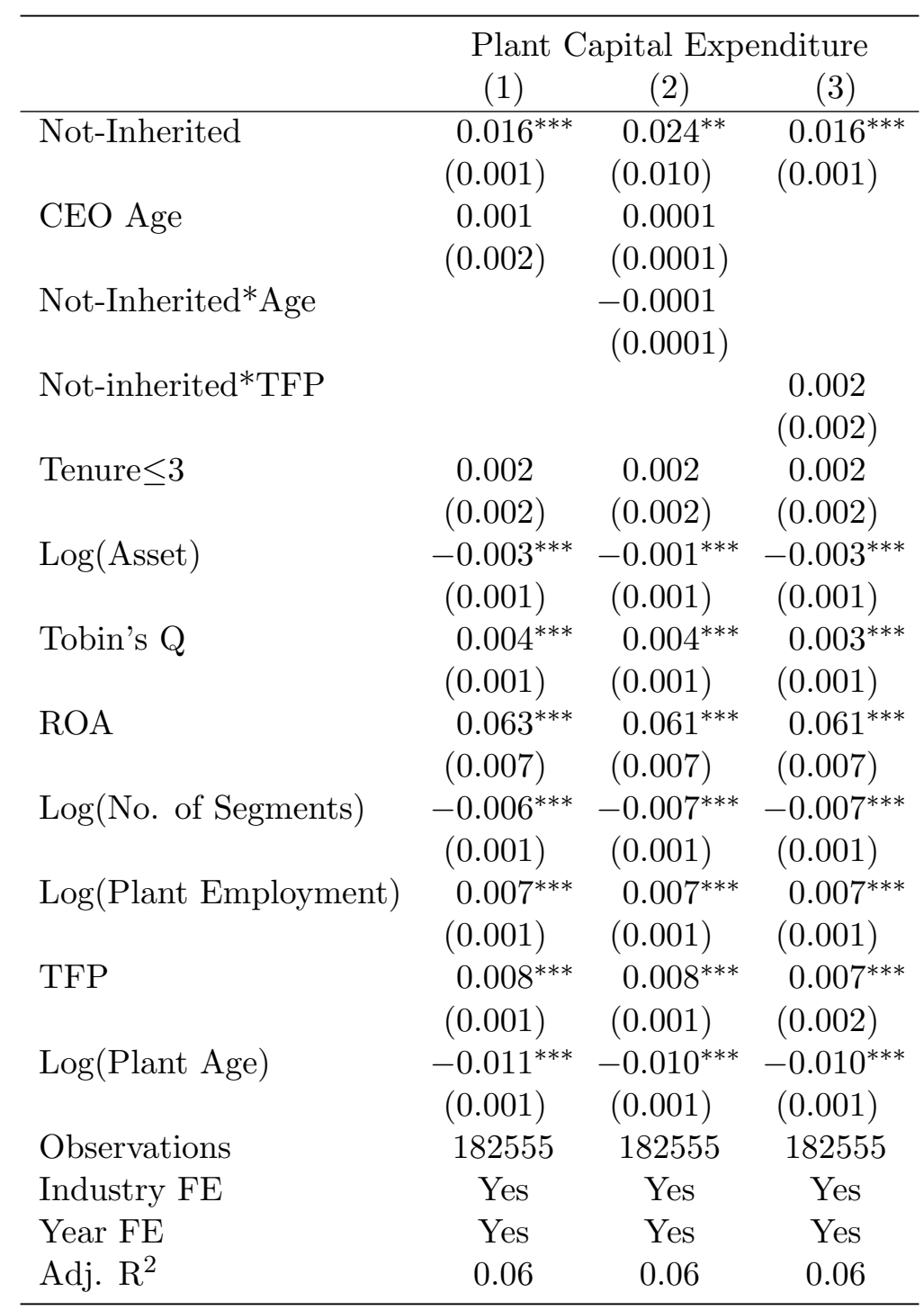


APPENDICES 


\section{APPENDIX A}

\section{Variable Description and Sample Construction for Chapter 2}

\section{Variable Definitions}

$\begin{array}{ll}\text { Variable } & \text { Description } \\ \text { CAR }_{(-1,+1)} & \text { Cumulative abnormal returns over three days CRSP } \\ & \text { surrounding the announcement calculated } \\ & \text { using a market model adjusted by the value- } \\ & \text { weighted CRSP market index. The parame- } \\ & \text { ters for the market model are estimated over } \\ & \text { the }(-205,-6) \text { interval. } \\ & \text { Weighted average of CAR }(-1,+1) \text { for the ac- CRSP } \\ & \text { quirer and target, where the weight is the } \\ & \text { market value of the two firms three days be- } \\ \text { Total CAR }(-1,+1) & \text { fore the announcement. } \\ & =1 \text { if the target and the acquirer share the SDC } \\ & \text { same primary two-digit SIC, } 0 \text { otherwise. } \\ \text { Related } & =1 \text { if } 100 \% \text { of the transaction value was paid SDC } \\ \text { Some Stock } & \text { by cash, } 0 \text { otherwise. } \\ & =1 \text { if at least some part of the transaction SDC } \\ & \text { was paid by stock, } 0 \text { otherwise. }\end{array}$


Private Acquirer

Premium

Asset

Market-to-book ratio

RelaSize

52-W price high

Output

Investment

Material
$=1$ if the acquiring firm is a not publicly- SDC

listed, 0 otherwise.

Transaction value recorded by SDC divided SDC

by the market value of the target 4 weeks

before the announcement.

Book value of book assets (item 6)

COMPUSTAT

(Book value of asset - book value of equity +

COMPUSTAT

market value of equity)/Book value of assets.

Target's Market Value/(Target's Market CRSP

Value + Acquirer's Market Value), where the

market value three days before announce-

ment is used.

Target's 52-week highest stock price divided

CRSP

by the target price 30 days before the announcement.

Plant level output is total value of shipments, ASM/CMF

deflated to 1987 dollars using industry-

specific price index from the NBER-CES Pro-

ductivity Database.

Plant level capital expenditure, deflated to

$\mathrm{ASM} / \mathrm{CMF}$

1987 dollars using industry-specific price index from the NBER-CES Productivity

Database.

Sum of plant's expenditure on parts and in- ASM/CMF

termediate goods, fuel, energy, electricity and

contract work, deflated to 1987 dollars using

industry-specific price index from the NBER-

CES Productivity Database. 
Capital Stock

Payroll

Employment

Wage

Nonproduction Worker

Fringe Benefits
Total assets at the beginning of the year. In ASM/CMF 1986 the ASM stopped collecting the book value of assets in non-census years. For years since 1988, I employ recursive perpetual inventory formula using the nearest available book value of assets as the initial value. These values are written forward annually with nominal capital expenditure and depreciated with the economic depreciation rate at the industry level.

Total salaries and wages, expressed in 2005 ASM/CMF US dollars.

Total number of workers.

$\mathrm{ASM} / \mathrm{CMF}$

Average annual wage per worker, expressed ASM/CMF in 2005 US dollars.

supervisor level, sales, advertising, clerical, and routine office functions".

Include health insurance, pension plans, and ASM/CMF other benefits. 


\section{Sample Construction}

I provide detailed information on how I match the target firms in SDC to the ASM/CMF below. I match the target firm's CUSIP to the ASM/CMF's firm identifier (FIRMID) through a "COMPUSTAT-Standard Statistical Establishment List (SSEL) Bridge" file maintained by the Census Bureau. This bridge file is created by Steven J. Davis, John Haltiwanger, Ron Jarmin, and Javier Miranda (2006) "Volatility and Dispersion in Business Growth Rates: Publicly Traded versus Privately Held Firms." I also hand-match some of the unmatched target firms by matching firm name and address between SDC and SSEL, which is the Business Register data set of the U.S. Census Bureau. The overall matched cases represent over $70 \%$ of all mergers in my sample. The unmatched cases can be due to different definitions of parent firms, change in CUSIPs, and naming differences.

Firms in the Census are defined based on operational control, and all plants under the operational control of a parent firm share the same FIRMID. All the plants in the Census are assigned an invariant plant identifier "LBDNUM". The "LBDNUM" allows me to track the same target plants forwards and backwards in time. Firm identifiers can be broken primarily as a result of firm's merger and acquisition activity as well as expansions from single unit establishment entities to multi unit entities. Therefore, I match SDC to ASM/CMF the year before the merger completion year to obtain target firms' FIRMIDs and all the plants owned by the target firm.

Presumably, after an ownership change, the acquired plants' FIRMID would be replaced by the acquiring firm's FIRMID. However, the Census Bureau often fails to update this information in a timely manner to reflect such changes. This limitation makes it extremely difficult for me to trace accurately when and whether an acquired plant is sold to another firm (with a new FIRMID) after a takeovers. As a result, this study does not explicitly examines divestiture decisions.

I construct the sample of control plants based on three-digit SIC industry, total number of employees, and TFP. Note that from 1997, the Census Bureau adopts the NAICS industry definition. I use a concordance file provided by the Census Bureau to convert NAICS to 1987 SIC. 


\section{APPENDIX B}

\section{Variable Description for Chapter 4}

\section{Variable Definitions}

\begin{tabular}{|c|c|c|c|}
\hline Variable & Description & Unit of Obs. & Source \\
\hline \multicolumn{4}{|c|}{ Dependent Variables } \\
\hline NOCHANGE & $\begin{array}{l}\text { Dummy variable is equal to } \\
\text { one if there is no change in } \\
\text { the firm's number of estab- } \\
\text { lishments and segments, and } \\
\text { zero otherwise. A segment is } \\
\text { defined as a collection of es- } \\
\text { tablishments with the same } 3 \text { - } \\
\text { digit SIC code. }\end{array}$ & Firm-year & LBD \\
\hline ENTRY & $\begin{array}{l}\text { Dummy variable is equal to } \\
\text { one if the firm enters a new } \\
\text { segment, and zero otherwise. }\end{array}$ & Firm-year & LBD \\
\hline EXIT & $\begin{array}{l}\text { Dummy variable is equal to } \\
\text { one if the firm exits an exist- } \\
\text { ing segment, and zero other- } \\
\text { wise. }\end{array}$ & Firm-year & LBD \\
\hline
\end{tabular}


INCREASE Dummy variable is equal to Firm-year

one if the firm increases

the number of establishments

within an existing segment, and zero otherwise.

DECREASE Dummy variable is equal to Firm-year

LBD one if the firm decreases the number of establishments within an existing segment, and zero otherwise.

De Novo

Dummy variable is equal to

one if the establishment is built from scratch and zero if the establishment is acquired from another firm.

Employment

Difference

Firm-year

LBD

Growth year's number of employees and previous year's number of employees divided by previous years number of employees.

Employment Ratio of total employment at (Entry) new segments to firm's total employment in the previous year, conditional upon EN$\mathrm{TRY}=1$. 


$$
\begin{array}{ll}
\text { Employment } & \text { Ratio of total employment at } \\
\text { (Exit) } & \text { exiting segments to firm's to- } \\
& \text { tal employment in previous } \\
& \text { year, conditional upon EXIT } \\
& =1 .
\end{array}
$$

Capital Ex- Ratio of capital expenditure Firm-year Compustat penditure to previous year's assets.

R\&D Expendi- Ratio of R\&D expenditure to Firm-year Compustat ture previous year's assets.

TFP Total Factor Productivity, es- Establishment-year ASM/CMF timated as the residual from regressing output on wage bill, capital stock, and material cost.

Log(Value- Log (ratio of total output less Establishment-year ASM/CMF

\begin{tabular}{|c|c|c|c|}
\hline \multicolumn{4}{|c|}{ Independent Variables } \\
\hline CEO Age & CEO's age & Firm-year & Compact D \\
\hline Age under 50 & $\begin{array}{l}\text { Dummy variable is equal to } \\
\text { one if the CEO's age is below } \\
50 \text { years old, and zero other- } \\
\text { wise. }\end{array}$ & Firm-year & Compact D \\
\hline Age 50-59 & $\begin{array}{l}\text { Dummy variable is equal to } \\
\text { one if the CEO's age is be- } \\
\text { tween } 50 \text { and } 59 \text {, inclusive, } \\
\text { and zero otherwise. }\end{array}$ & Firm-year & Compact D \\
\hline
\end{tabular}
added per labor and materials costs to worker) number of employees).

Plant Capital Capital expenditure divided Establishment-year ASM/CMF Expenditure by capital stock. 


\begin{tabular}{|c|c|c|c|}
\hline Tenure $\leq 3$ & $\begin{array}{l}\text { Dummy variable is equal to } \\
\text { one if it is during the first } \\
\text { three years of the CEO's } \\
\text { tenure, and zero otherwise. }\end{array}$ & Firm-year & Compact D \\
\hline Log(Asset) & $\begin{array}{l}\text { Log (book value of assets in } \\
2005 \text { millions of USD). }\end{array}$ & Firm-year & Compustat \\
\hline ROA & $\begin{array}{l}\text { Ratio of operating income be- } \\
\text { fore depreciation to previous } \\
\text { year's assets. }\end{array}$ & Firm-year & Compustat \\
\hline Tobin's Q & $\begin{array}{l}\text { Ratio of market value of assets } \\
\text { to book value of assets. }\end{array}$ & Firm-year & Compustat \\
\hline Stock Returns & $\begin{array}{l}\text { Buy-and-hold returns over } \\
\text { previous fiscal year. }\end{array}$ & Firm-year & Compustat \\
\hline Cash & $\begin{array}{l}\text { Ratio of cash to book value of } \\
\text { assets. }\end{array}$ & Firm-year & Compustat \\
\hline $\begin{array}{l}\log (\text { No. } \quad \text { of } \\
\text { Segments })\end{array}$ & $\begin{array}{l}\text { Log(total number of segments } \\
\text { in which a firm operates with } \\
\text { at least one establishment) }\end{array}$ & Firm-year & LBD \\
\hline $\begin{array}{l}\log (\text { No. } \quad \text { of } \\
\text { Plants })\end{array}$ & $\begin{array}{l}\text { Log(total number of plants a } \\
\text { firm owns). }\end{array}$ & Firm-year & LBD \\
\hline $\begin{array}{l}\text { Log(Plant } \\
\text { Age })\end{array}$ & Log(age of establishment) & Establishment-year & LBD \\
\hline $\begin{array}{l}\text { Log(Plant Em- } \\
\text { ployment })\end{array}$ & $\begin{array}{l}\log (\text { number of employees in } \\
\text { the establishment) }\end{array}$ & Establishment-year & LBD \\
\hline Not-Inherited & $\begin{array}{l}\text { Dummy variable is equal to } \\
\text { one if the plant is either } \\
\text { bought or started by the cur- } \\
\text { rent CEO, otherwise zero. }\end{array}$ & Establishment-year & $\begin{array}{l}\text { Compact } \\
\mathrm{D} \text { with } \\
\mathrm{ASM} / \mathrm{CMF}\end{array}$ \\
\hline
\end{tabular}


Figure B.1: Union Membership across states, years and industries

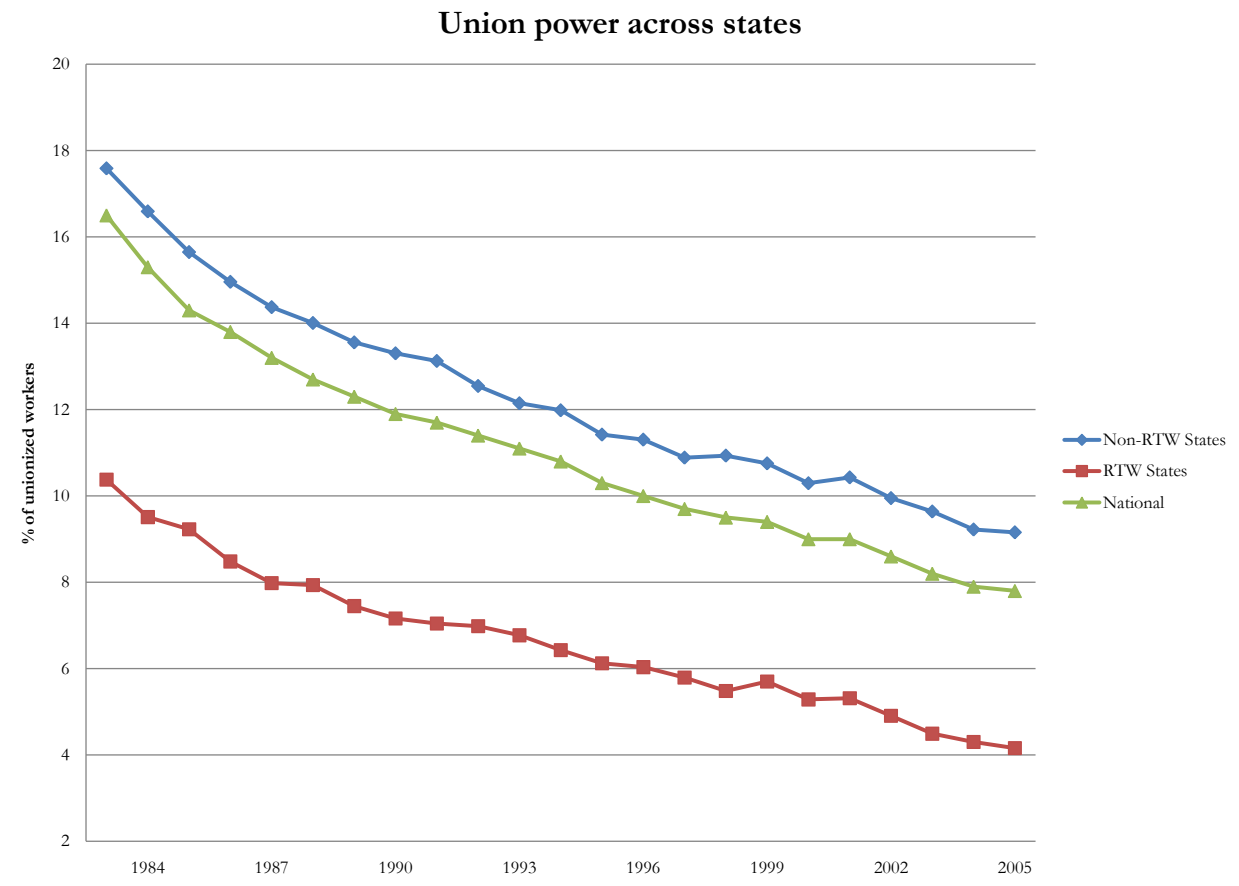

Union membership across industries

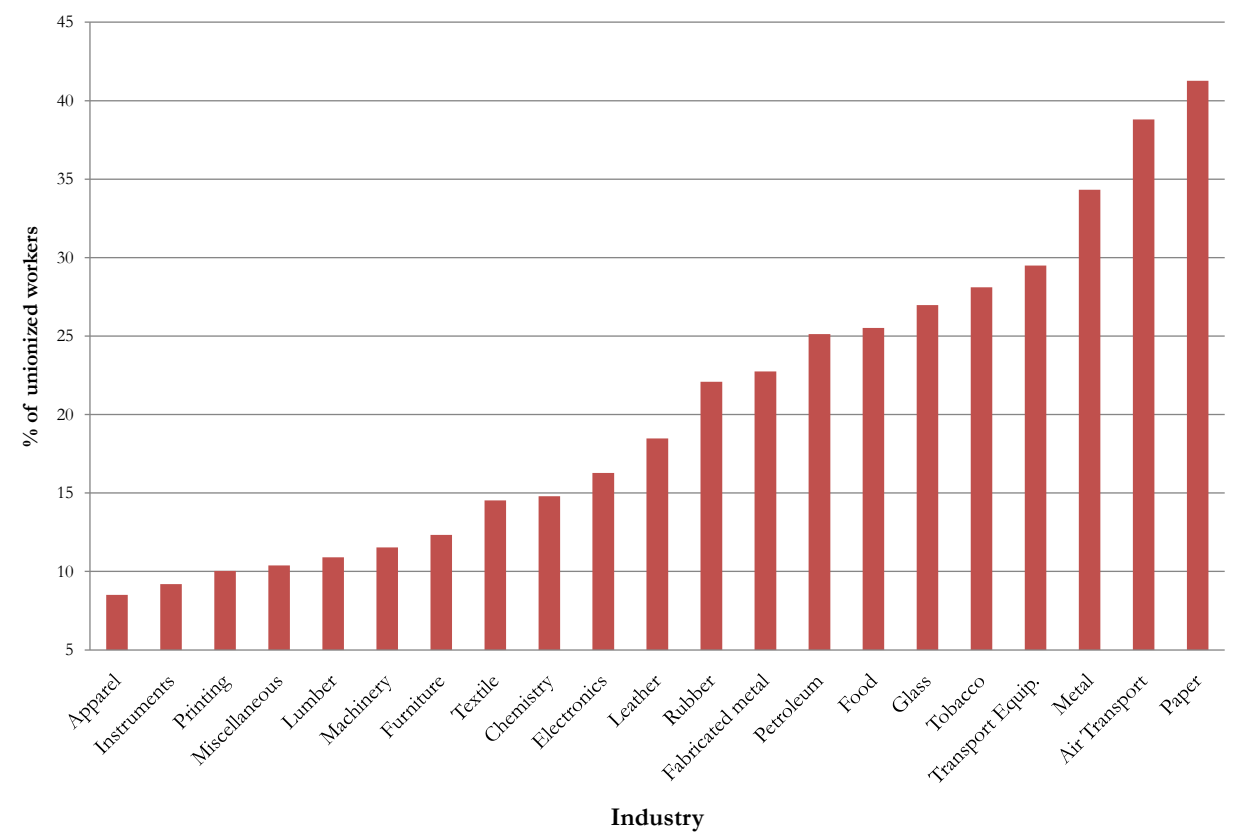


Figure B.2: Map of Right-to-work law states

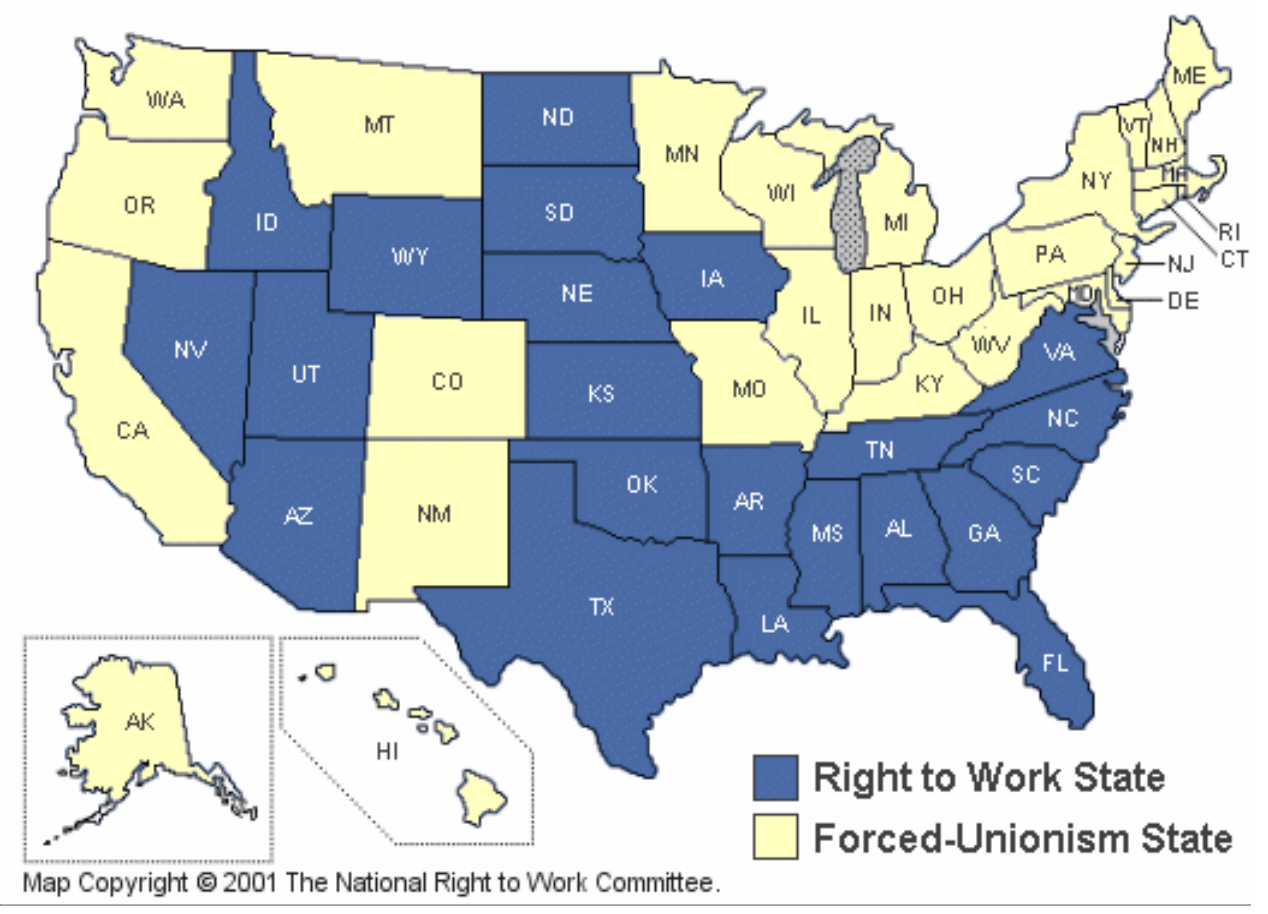

Year of Right-to-work law enactment

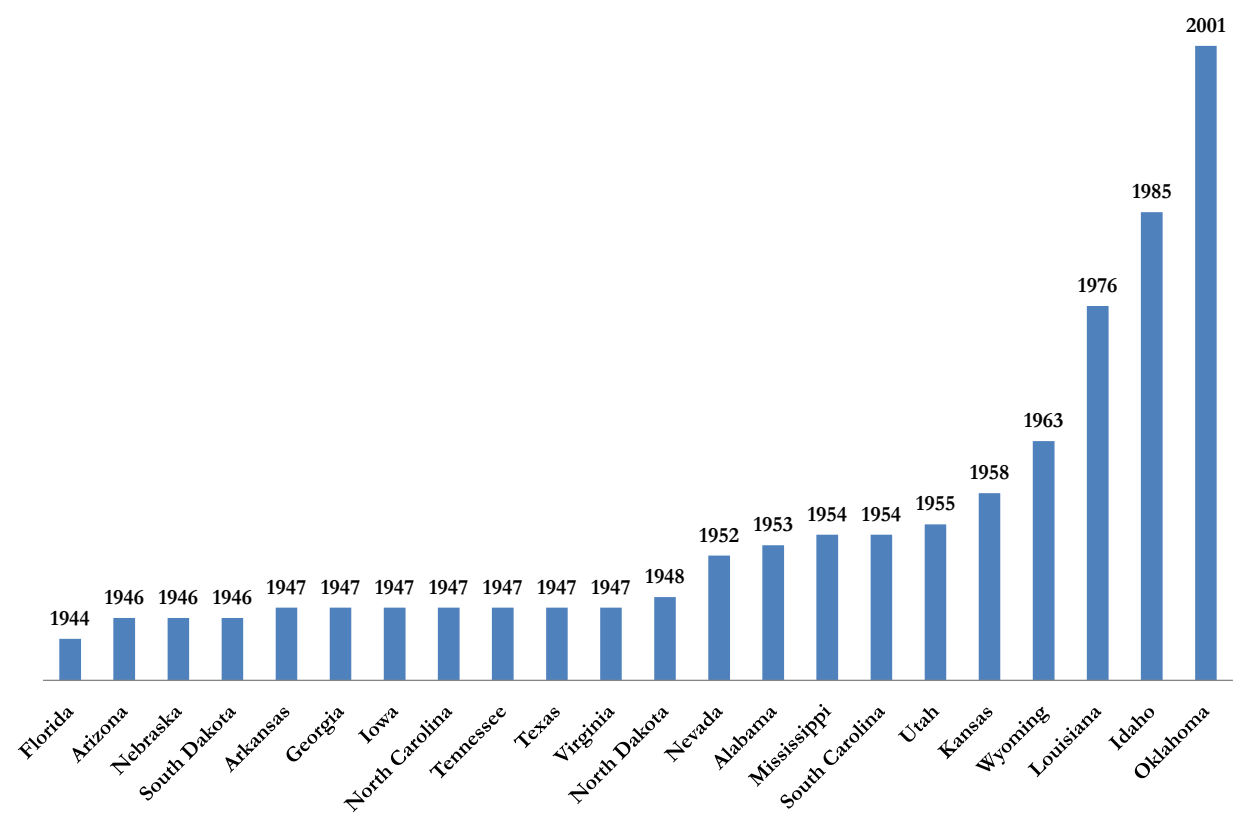


Figure B.3: Real Investment Activities across years

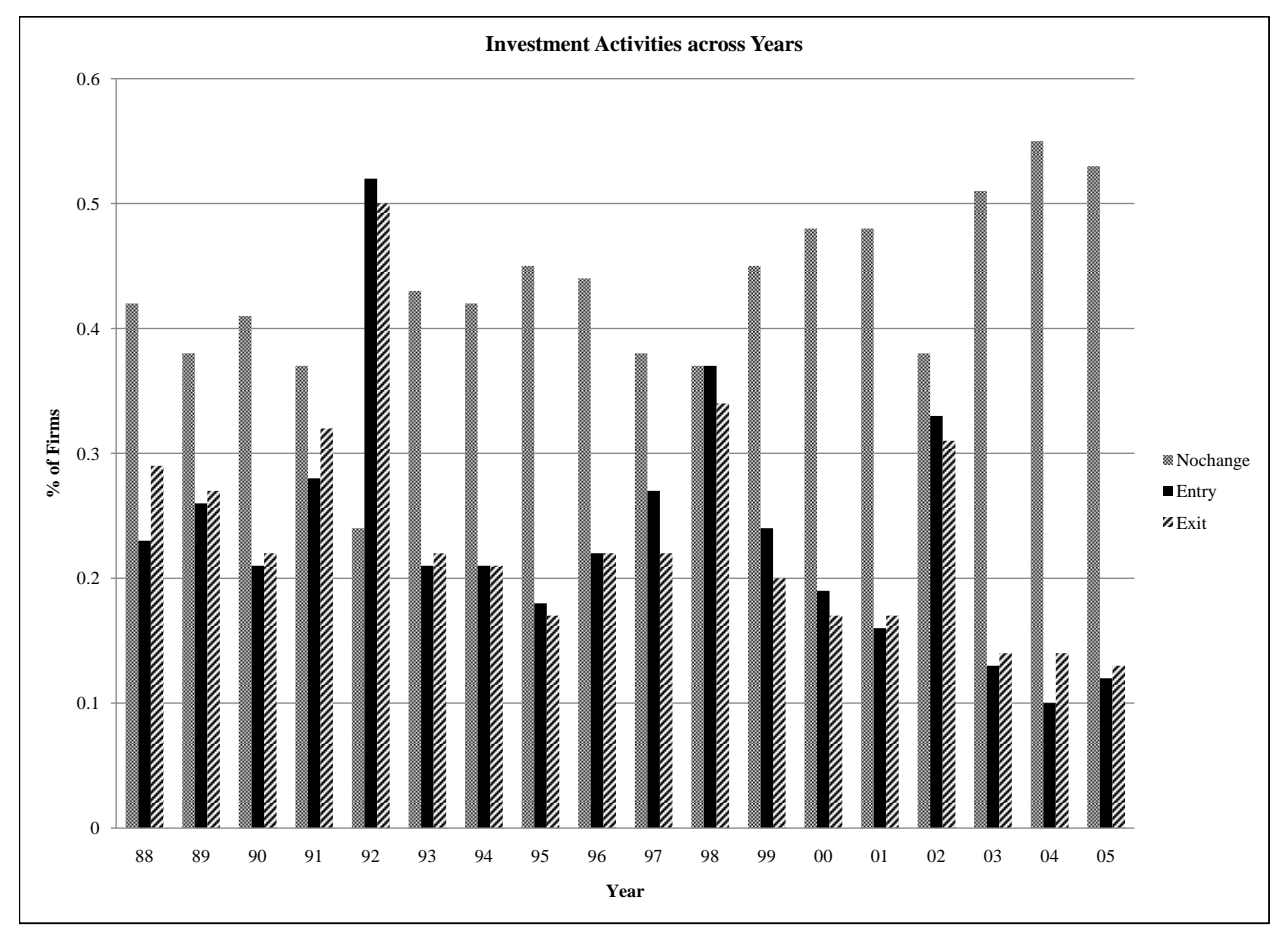


BIBLIOGRAPHY 


\section{BIBLIOGRAPHY}

Abowd, J. (1989). The effect of wage bargains on the stock market value of the firm. American Economic Review 79, 774-800.

Ahern, K. (2010). Bargaining power and industry dependence in mergers. Journal of Financial Economics, forthcoming.

Andrade, G., M. Mitchell, and E. Stafford (2001). New evidence and perspectives on mergers. Journal of Economic Perspectives 15, 103-120.

Atanassov, J. and E. H. Kim (2009). Labor and corporate governance: International evidence from restructuring decisions. Journal of Finance 64, 341-374.

Baker, M., X. Pan, and J. Wurgler (2010). A reference point theory of mergers and acquisitions. Working paper, Harvard University and New York Unviersity.

Barber, B. M. and J. D. Lyon (1996). Detecting abnormal operating performance: The empirical power and specification of test statistics. Journal of Financial Economics 41, $359-400$.

Bargeron, L. L., F. P. Schlingemann, R. M. Stulz, and C. J. Zutter (2008). Why do private acquirers pay so little compared with public acquirers? Journal of Financial Economics 89, 375-390.

Barry, T. H. and D. A. Macpherson (2003). Union membership and coverage database from the current population survey: Note. Industrial and Labor Relations Review 56, 349-354.

Bates, T. H. and M. L. Lemmon (2003). Breaking up is hard to do? An analysis of termination fee provisions and merger outcomes. Journal of Financial Economics 69, $460-504$.

Bebchuk, L. A. and L. A. Stole (1993). Do short-term objectives lead to under- or overinvestment in long-term projects? Journal of Finance 48, 719-729.

Becker, B. (1995). Union rents as a source of takeover gains among target shareholders. Industrial and Labor Relations Review 49, 3-19.

Ben-David, I., J. R. Graham, and C. R. Harvey (2010). Do short-term objectives lead to under- or overinvestment in long-term projects? Working paper, Ohio State University and Duke University.

Bertrand, M. and S. Mullainathan (2003). Enjoying the quiet life? Corporate governance and managerial preferences. Journal of Political Economy 111, 1043-1075. 
Betton, S., B. E. Eckbo, and K. S. Thorburn (2008). Corporate takeovers. In B. E. Eckbo (Ed.), Handbook of Corporate Finance: Empirical Corporate Finance. Elsevier/NorthHolland.

Boot, A. W. (1992). Why hang on to losers? Divestitures and takeovers. Journal of Finance 47, 1401-1423.

Bradley, M., A. Desai, and E. H. Kim (1988). Synergistic gains from corporate acquisitions and their division between the stockholders of target and acquiring firms. Journal of Financial Economics 21, 3-40.

Bronars, S. G. and D. R. Deere (1991). The threat of unionization, the use of debt and the preservation of shareholder wealth. Quarterly Journal of Economics 106, 231-254.

Brown, C. and J. L. Medoff (1988). The impact of firm acquisition on labor. In A. J. Auerbach (Ed.), Corporate Takeovers: Causes and Consequences. University of Chicago Press, Chicago.

Chen, H., M. Kacperczyk, and H. Ortiz-Molina (2011). Labor unions, operating flexibility, and the cost of equity. Journal of Financial and Quantitative Analysis 46, 25-58.

Chevalier, J. and G. Ellison (1999). Career concerns of mutual fund managers. Quarterly Journal of Economics 114, 389-432.

Coles, J. L., N. D. Daniel, and L. Naveen (2006). Managerial incentives and risk-taking. Journal of Financial Economics 79, 431-468.

Core, J. and W. Guay (2002). Estimating the value of employee stock option portfolios and their sensitivities to price and volatility. Journal of Accounting Research 40, 613-630.

Davis, S. J., J. Haltiwanger, R. Jarmin, J. Lerner, and J. Miranda (2008). Private equity, jobs, and productivity. Working paper, U.S. Census Bureau.

Davis, S. J., J. Haltiwanger, R. Jarmin, J. Lerner, and J. Miranda (2009). Private equity and employment. Working paper, U.S. Census Bureau.

DeAngelo, H. and L. DeAngelo (1991). Union negotiations and corporate policy: A study of labor concessions in the domestic steel industry during the 1980s. Journal of Financial Economics 30, 3-43.

Devos, E., P.-R. Kadapakkam, and S. Krishnamurthy (2009). How do mergers create value? A comparison of taxes, market power, and efficiency improvements as explanations for synergies. Review of Financial Studies 22, 1179-1211.

DiNardo, J. E. and D. S. Lee (2004). Economic impacts of new unionization on private sector employers: 1984-2001. Quarterly Journal of Economics 119, 1383-1441.

Edmans, A., I. Goldstein, and W. Jiang (2010). Takeover activity and target valuations: Evidence of feedback in financial markets. Working paper, University of Pennsylvania and Columbia University.

Ellwood, D. T. and G. Fine (1987). The impact of right-to-work laws on union organizing. Journal of Political Economy 95, 250-273. 
Fama, E. F. (1980). Agency problems and the theory of the firm. Journal of Political Economy 88, 288-307.

Farber, H. (1984). Right-to-work laws and the extent of unionization. Journal of Labor Economics 2, 319-352.

Fox, F. V. and B. M. Staw (1979). The trapped administrator: Effects of job security and policy resistance upon commitment to a course of action. Administrative Science Quarterly 24, 449-471.

Freeman, R. B. and J. L. Medoff (1984). What Do Unions Do? New York: Basic Books.

Ghosh, A. (2001). Does operating performance really improve following corporate acquisitions? Journal of Corporate Finance 7, 151-178.

Gibbons, R. and K. J. Murphy (1992). Optimal incentive contracts in the presence of career concerns: Theory and evidence. Journal of Political Economy 100, 468-505.

Goel, A., V. Nanda, and M. P. Narayanan (2004). Career concerns and resources allocation in conglomerates. Review of Financial Studies 17, 99-128.

Gompers, P., J. Ishii, and A. Metrick (2003). Corporate governance and equity prices. Quarterly Journal of Economics 118, 107-155.

Gudell, S. M. (2010). Serial ceos and their career concerns. Working paper, University of Rochester.

Harford, J. (2005). What drives merger waves? Journal of Financial Economics 77, 529560 .

Hartzell, J. C., E. Ofek, and D. Yermack (2004). What's in it for me? CEOs whose firms are acquired. Review of Financial Studies 17, 37-61.

Healy, P. M., K. G. Palepu, and R. S. Ruback (1992). Does corporate performance improve after mergers? Journal of Financial Economics 31, 135-175.

Hietala, P., S. N. Kaplan, and D. T. Robinson (2003). What is the price of hubris? Using takeover battles to infer overpayments and synergies. Financial Management 32, 5-31.

Hirano, K., G. Imbens, and G. Ridder (2003). Efficient estimation of average treatment effects using the estimated propensity score. Econometrica 71, 1161-1189.

Hirshleifer, D., A. Low, and S. H. Teoh (2010). Are overconfident CEOs better innovators? Working paper, University of California, Irvine.

Hirshleifer, D. and A. V. Thakor (1992). Managerial conservatism, project choice, and debt. Review of Financial Studies 5, 437-470.

Hoberg, G. and G. Phillips (2010). Product market synergies and competition in mergers and acquisitions: A text-based analysis. Review of Financial Studies 23, 3773-3811.

Holmes, T. (1998). The effects of state policies on the location of industry: Evidence from state borders. Journal of Political Economy 106, 667-705. 
Holmstrom, B. (1982). Managerial incentive problems: A dynamic perspective. In Essays in Economics and Management in Honor of Lars Wahlbeck. Helsinki: Swedish School of Economics.

Holmstrom, B. (1999). Managerial incentive problems: A dynamic perspective. Review of Economic Studies 66, 169-182.

Holmstrom, B. and J. Ricart-i-Costa (1986). Managerial incentives and capital management. Quarterly Journal of Economics 101, 835-860.

Hong, H., J. D. Kubik, and A. Solomon (2000). Security analysts' career concerns and herding of earnings forecasts. RAND Journal of Economics 31, 121-144.

Houston, J. F., C. M. James, and M. D. Ryngaert (2001). Where do merger gains come from? Bank mergers from the perspective of insiders and outsiders. Journal of Financial Economics 60, 285-331.

Huson, M. R., R. Parrino, and L. Starks (2001). Internal monitoring mechanisms and CEO turnover: A long-term perspective. Journal of Finance 56, 2265-2297.

Imbens, G. and J. Wooldridge (2007). Lecture 1: Estimation of average treatment effects under unconfoundedness. In: "What's New in Econometrics" NBER Summer 2007 Seminar.

Jarmin, R. and J. Miranda (2002). The longitudinal business database. Working paper, U.S. Census Bureau.

Jarrell, G. A., J. A. Brickley, and J. M. Netter (1988). The market for corporate control: The empirical evidence since 1980. Journal of Economic Perspectives 2, 49-68.

Jensen, M. (1986). Agency costs of free-cash-flow, corporate finance, and takeovers. American Economic Review 76, 323-329.

Jensen, M. and R. S. Ruback (1983). The market for corporate control: The scientific evidence. Journal of Financial Economics 11, 5-50.

Jenter, D. and F. Kanaan (2010). CEO turnover and relative performance evaluation. Journal of Finance, forthcoming.

Jin, L. and A. Scherbina (2010). Inheriting losers. Review of Financial Studies, forthcoming.

Kaplan, S. N. (1989). The effects of management buyouts on operating performance and value. Journal of Financial Economics 24, 217-254.

Kaplan, S. N. (2000). Introduction. In S. N. Kaplan (Ed.), Mergers and Productivity. University of Chicago Press, Chicago.

Kaplan, S. N. and B. A. Minton (2010). How has CEO turnover changed? Working paper, The Ohio State University.

Kaplan, S. N., M. L. Mitchell, and K. H. Wruck (2000). A clinical exploration of value creation and destruction in acquisitions: Organization design, incentives and internal capital markets. In S. N. Kaplan (Ed.), Mergers and Productivity. University of Chicago Press, Chicago. 
Klasa, S., W. Maxwell, and H. Ortiz-Molina (2009). The strategic use of corporate cash holdings in collective bargaining with labor unions. Journal of Financial Economics 92, $421-442$.

Lalonde, R. J., G. Marschke, and K. Troske (1996). Using longitudinal data on establishments to analyze the effects of union organizing campaigns in the united states. Annales D'Économie et de Statistique 41/42, 155-185.

Lamont, O. (2002). Macroeconomic forecasts and microeconomic forecasters. Journal of Economic Behavior and Organization 16, 265-280.

Lang, L. H. P., R. M. Stulz, and R. A. Walkling (1989). Managerial performance, Tobin's Q, and the gains from successful tender offers. Journal of Financial Economics 24, 137-154.

Lee, D. S. and A. Mas (2010). Long-run impacts of unions on firms: New evidence from financial markets, 1961-1999. Working paper, Princeton University.

Levin, M., K. Li, and F. Zhang (2010). Deal or no deal: Hormones and the mergers and acquisitions game. Management Science 56, 1462-1483.

Li, K. and N. R. Prabhala (2007). Self-selection models in corporate finance. In B. E. Eckbo (Ed.), Handbook of Corporate Finance: Empirical Corporate Finance. Elsevier/NorthHolland.

Lichtenberg, F. R. (1992). Corporate Takeovers and Productivity. MIT Press, Cambridge, MA.

Lichtenberg, F. R. and D. Siegel (1990a). The effect of leveraged buyouts on productivity and related aspects of firm behavior. Journal of Financial Economics 27, 165-194.

Lichtenberg, F. R. and D. Siegel (1990b). The effect of ownership changes on the employment and wages of central office and other personnel. Journal of Law and Economics 33, $383-408$.

Maksimovic, V. and G. Phillips (2001). The market for corporate assets: Who engages in mergers and asset sales and are there efficiency gains? Journal of Finance 56, 2019-2065.

Maksimovic, V. and G. Phillips (2002). Do conglomerate firms allocate resources inefficiently across industries? Theory and evidence. Journal of Finance 57, 721-767.

Maksimovic, V. and G. Phillips (2008). The industry life-cycle, acquisitions and investment: Does firm organization matter? Journal of Finance 63, 673-707.

Maksimovic, V., G. Phillips, and N. R. Prabhala (2010). Post-merger restructuring and the boundaries of the firm. Journal of Financial Economics, forthcoming.

Malmendier, U. and G. Tate (2008a). Who makes acquisitions? CEO overconfidence and the market's reaction. Journal of Financial Economics 89, 20-43.

Malmendier, U. and G. A. Tate (2005). CEO overconfidence and corporate investment. Journal of Finance 60, 2661-2700.

Malmendier, U. and G. A. Tate (2008b). Who makes acquisitions? CEO overconfidence and the market's reaction. Journal of Financial Economics 89, 20-43. 
Martin, K. J. and J. McConnell (1991). Corporate performance, corporate takeovers, and management turnover. Journal of Finance 46, 671-687.

Masulis, R., C. Wang, and F. Xie (2007). Corporate governance and acquirer returns. Journal of Finance 62, 1851-1889.

Matsa, D. M. (2010). Capital structure as a strategic variable: Evidence from collective bargaining. Journal of Finance 65, 1197-1232.

McGuckin, R. and S. V. Nguyen (1995). On productivity and plant ownership change: New evidence from the longitudinal research database. RAND Journal of Economics 26, $257-276$.

McGuckin, R. and S. V. Nguyen (2001). The impact of ownership changes: A view from labor markets. International Journal of Industrial Organization 19, 739-762.

Mitchell, M. L. and J. H. Mulherin (1996). The impact of industry shocks on takeover and restructuring activity. Journal of Financial Economics 41, 193-229.

Moeller, S. B., F. P. Schlingemann, and R. M. Stulz (2004). Firm size and the gains from acquisitions. Journal of Financial Economics 73, 201-228.

Moeller, S. B., F. P. Schlingemann, and R. M. Stulz (2005). Wealth destruction on a massive scale? A study of acquiring-firm returns in the recent merger wave. Journal of Finance 60, 757-782.

Moeller, T. (2005). Let's make a deal! How shareholder control impacts merger payoffs. Journal of Financial Economics 76, 167-190.

Narayanan, M. P. (1985). Managerial incentives for short-term results. Journal of Finance 40, 1469-1484.

Newman, R. J. (1983). Industry migration and growth in the south. Review of Economics and Statistics 65, 76-86.

Officer, M. S. (2003). Termination fees in mergers and acquisitions. Journal of Financial Economics 69, 431-467.

Ouimet, P. and R. Zarutskie (2010). Mergers and employee wages. Working paper, University of North Carolina, Chapel Hill.

Pagano, M. and P. F. Volpin (2005). Managers, workers, and corporate control. Journal of Finance 60, 841-868.

Pontiff, J., A. Shleifer, and M. Weisbach (1990). Reversions of excess pension assets after takeovers. RAND Journal of Economics 21, 600-613.

Prendergast, C. and L. Stole (1996). Impetuous youngsters and jaded old-timers: Acquiring a reputation for learning. Journal of Political Economy 104, 1105-1134.

Rajan, R. G. and L. Zingales (1998). Financial dependence and growth. American Economic Review 88, 559-586. 
Rauh, J. D. (2006). Own company stock in defined contribution pension plans: A takeover defense? Journal of Financial Economics 81, 379-410.

Ravenscraft, D. J. and F. M. Scherer (1989). The profitability of mergers. International Journal of Industrial Organization 7, 101-116.

Rhodes-Kropf, M. and D. T. Robinson (2008). The market for mergers and the boundaries of the firm. Journal of Finance 62, 1169-1211.

Roll, R. (1986). The hubris hypothesis of corporate takeovers. Journal of Business 59, $197-216$.

Rosett, J. G. (1990). Do union wealth concessions explain takeover premiums? Journal of Financial Economics 27, 263-282.

Ruback, R. S. and M. B. Zimmerman (1984). Unionization and profitability: Evidence from the capital market. Journal of Political Economy 92, 1134-1157.

S., R. and I. Rosenberg (2006). Nutrition and aging: Changes in the regulation of energy metabolism with aging. Physiological Reviews 86, 651-667.

Savor, P. G. and Q. Lu (2009). Do stock mergers create value for acquirers. Journal of Finance 64, 1061-1097.

Scharfstein, D. S. and J. C. Stein (1990). Herd behavior and investment. American Economic Review 80, 465-479.

Schoar, A. (2002). The effect of diversification on firm productivity. Journal of Finance 62, $2379-2403$.

Schwert, G. W. (1996). Markup pricing in mergers and acquisitions. Journal of Financial Economics 41, 153-192.

Schwert, G. W. (2000). Hostility in takeovers: In the eyes of the beholder? Journal of Finance 55, 2599-2640.

Seru, A. (2010). Firm boundaries matter: Evidence from conglomerates and r\&d activity. Journal of Financial Economics, forthcoming.

Servaes, H. (1991). Tobin's Q and the gains from takeovers. Journal of Finance 46, 409-419.

Servaes, H. (1994). Do takeover targets overinvest? Review of Financial Studies 7, 253-277.

Shleifer, A. and L. Summers (1988). Breach of trust in hostile takeovers. In A. J. Auerbach (Ed.), Corporate Takeovers: Causes and Consequences. University of Chicago Press, Chicago.

Shleifer, A. and R. Vishny (1988). Value maximization and the acquisition process. Journal of Economic Perspectives 2, 7-20.

Shleifer, A. and R. Vishny (1989). Management entrenchment: The case of manager-specific investments. Journal of Financial Economics 25, 123-139. 
Stein, J. C. (2002). Agency, information and corporate investment. In M. H. George Constantinides and R. Stulz (Eds.), Handbook of the Economics of Finance. Amsterdam: North Holland.

Sundaram, R. K. and D. L. Yermack (2007). Pay me later: Inside debt and its role in managerial compensation. Journal of Finance 62, 1551-1588.

Taylor, L. A. (2010). Why are CEOs rarely fired? Evidence from structural estimation. Journal of Finance, forthcoming.

Taylor, R. (1975). Age and experience as determinants of managerial information processing and decision making performance. Academy of Management Journal 18, 74-81.

Wang, C. and F. Xie (2009). Corporate governance transfer and synergistic gains from mergers and acquisitions. Review of Financial Studies 62, 822-858.

Weisbach, M. S. (1988). Outside directors and CEO turnover. Journal of Financial Economics 20, 431-460.

Weisbach, M. S. (1995). CEO turnover and the firm's investment decisions. Journal of Financial Economics 37, 159-188.

Wooldridge, J. M. (2002). Econometric Analysis of Cross Section and Panel Data. MIT Press, Cambridge, MA.

Wulf, J. (2004). Do CEOs in mergers trade power for premium? Evidence from "mergers of equals". Journal of Law, Economics, and Organization 20, 60-101.

Xuan, Y. (2009). Empire-building or bridge-building? evidence from new CEOs' internal capital allocation decisions. Review of Financial Studies 22, 4919-4948.

Yang, L. (2008). The real determinants of asset sales. Journal of Finance 62, 2231-2262.

Yim, S. (2010). The acquisitiveness of youth: CEO age and acquisition behavior. Working Paper, Harvard University. 